الفاروقيون ودورهم السياسي والحضاري في خاندش ببلاد الهند

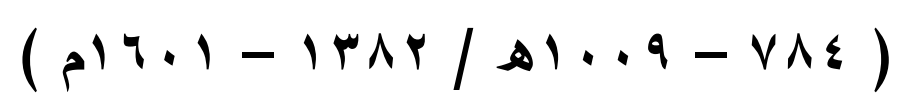

$$
\begin{aligned}
& \text { دكتور } \\
& \text { محمد على محمد إسماعيل } \\
& \text { مدرس التاريخ الإسلامي } \\
& \text { بكلية دار العلوم - جامعة المنيا }
\end{aligned}
$$




\section{مقدمـة - مقة}

الأسرة الفاروقية هي من الأسر الحاكمة التي ظهرت في الهند ، حيث قاموا بتأسيس

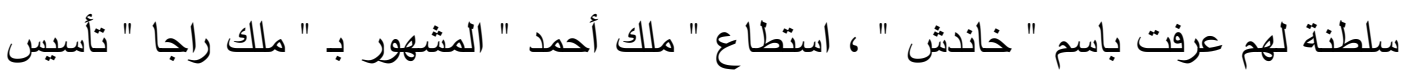
تلك السلطنة وذلك حين ضعفت سلطة بني تغلق (') في دهلي (r) خاصة بعد وفاة فيروز شاه

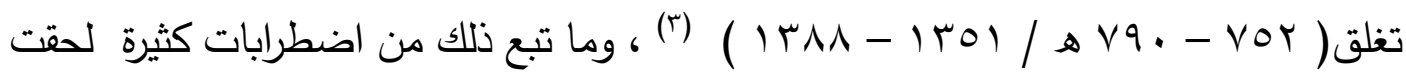
بالتغليين ، وهنا فكر ملك راجا في الاستقلال عن سلطة دهلي ، مقتديا في ذلك بجاره "دلاور

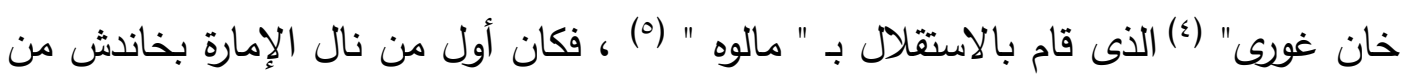

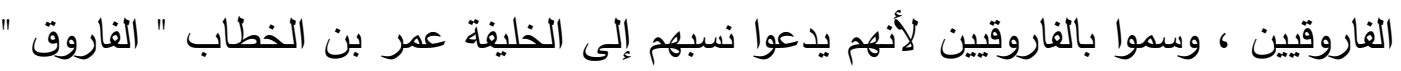

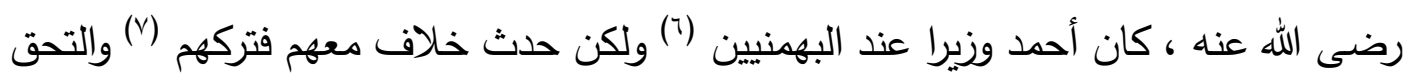
بالخدمة كجندي عادى في جيش دهلي، وبعدما أثبت جدارته للسلطان فيروز شاه قام فيروز

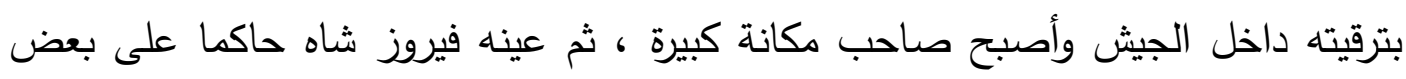

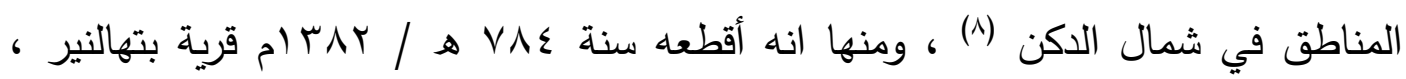
فاستأن ملك راجا السلطان في المكوث في هذا المكان ، وبعد وفاة فيروز شاه قام ملك راجا

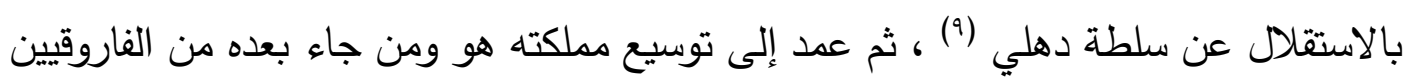
حتى اصبحت سلطنة خاندش في عهدهم من أهم الإمارات المستقلة التي ظهرت في الهند وكان لها تأثير كبير في الأحداث التاريخية ، وقد ربطتها علاقات سياسية وحضارية كبيرة مع غيرها من القوى الموجودة في تلك الفترة.

أهمية الدراسة :

تتجلي أهمية الدراسـة في كثـف اللثام عن تاريخ الأسـرة الفاروقية التي قامت على تكوين

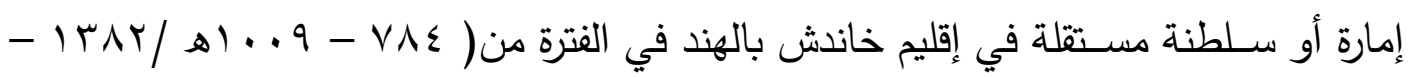

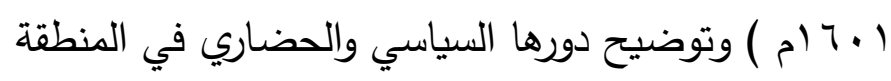

منهج الدراسة :

اعتمدت في دراســة الموضــوع علي المنهج التاريخي ، من حيث جمع المادة التاريخية

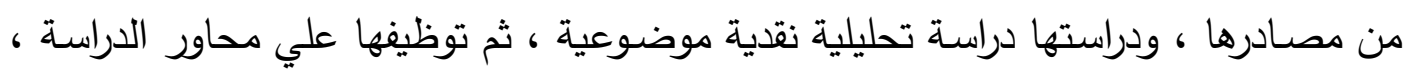
وذكر الروايات وآراء المؤرخين للوصول إلي النتائج والحقائق المتعلقة بموضوع الدراسة . 
الاراسات السابقة

لم أجد دراسة مستقلة تتاولت الحديث الثامل عن الفاروقيين بخاندش بالهند سياسيا وحضاريا ، على الرغم من أهمية هذا الإقليم وتلك الأسرة التي لعبت دورا مهما في الأحداث السياسية في منطقة نفوذهم وفي تاريخ المسلمين بالهند ككل ، وهذا ما دفعني للخوض في هذا الموضوع ، ولكن حين كتابة البحث واجهتني بعض الصعوبات كان من أهمها قلة المصادر

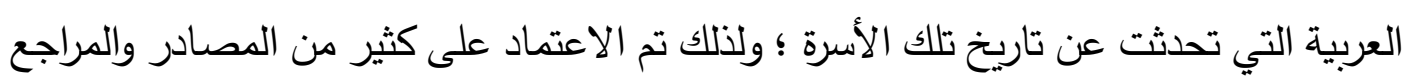
الأجنبية مما تطلب جهدا كبيرا في الترجمة . خطة الدراسة تشمل الدراسة على : مقدمة وتمهيد وثلاثة محاور وخاتمة ،

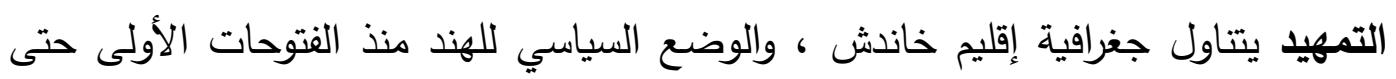

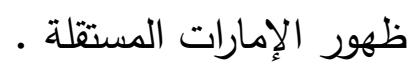
وجاء المحور الأول ليلق الضوء على نشأة الأسرة الفاروقية في خاندش وتوطيد نفوذها والتوسعات التي أضيفت تباعا إلى مناطق نفوذها بفضل جهود حكامها .

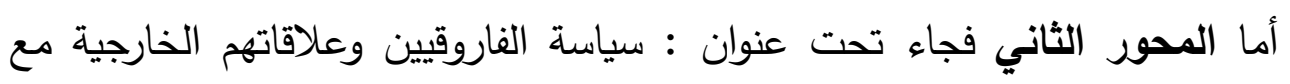
الإمارات المستقلة في الهند ، وتتاول التطور السياسي للسلطنة وعلاقاتها مع الإمارات المستقلة

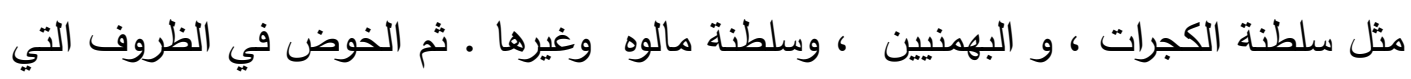

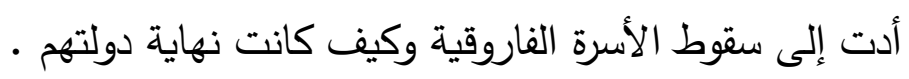
وجاء المحور الثالث ليعرض بعضا من المظاهر الحضارية للفاروقيين في خانش ولش سواء ما يتعلق بالجوانب الاقتصادية أو الجوانب العلمية والثقافية . تمهيد

\section{جغرافية إقليم خاندش أو ( خانديش )}

يقع إقليم خاندش في وسط غرب الهند إلى الثمال الغربي من الدكن ، يحده من الشرق

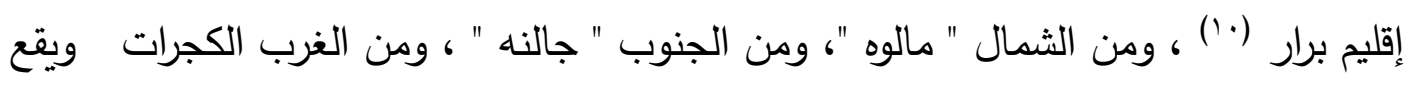

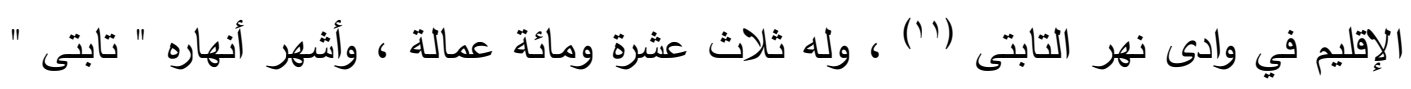

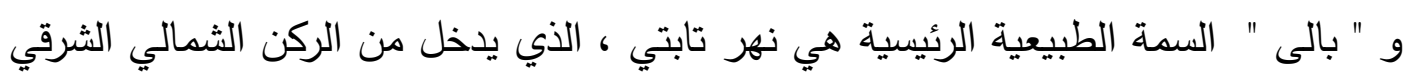

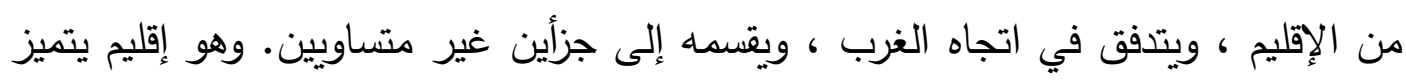


بالخصوبة ضم مساحة واسعة من التربة الغرينية الغنية. وتتعدد المدن والقرى الكبيرة والمزدهرة

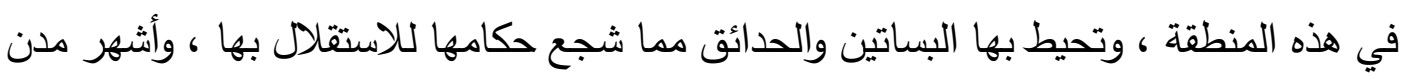

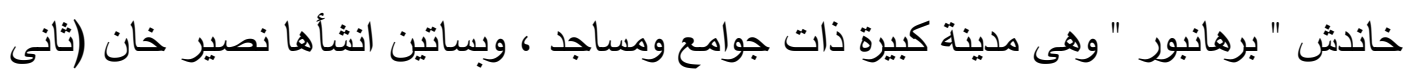

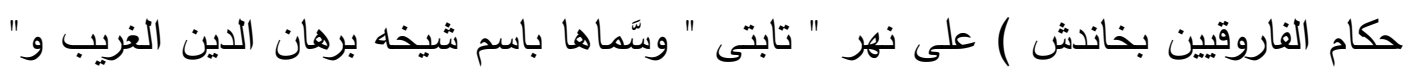

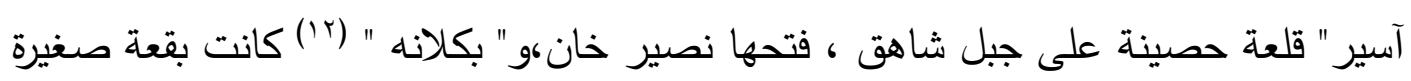

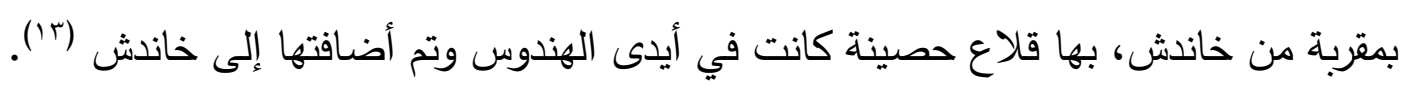

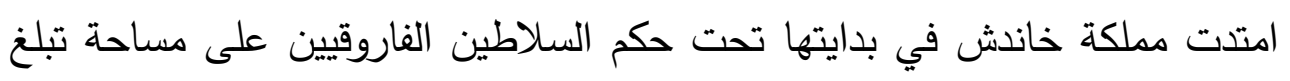
حوالي (اء . . 1 ميلاً مربعاً (ء) حتى استطاع عادل خان الثاني التوسع وبسط نفوذه شرقا على حساب راجات (10) " كوندوانا "و " جهاركند " الهندوسيين (1') . وهناك تكهنات مختلفة حول اشتقاق مصطلح Khandesh خاندش أو خانديش و فافترض البعض أن يكون مستمد من " تانديش " أرض العطش ، في إشارة إلي السهول الجافة والأمطار الثحيحة ، ويرى البعض أن خاندش بمعنى أرض الثوك التي كانت تكثر فيها ، ويميل البعض إلى الاعتقاد في اشتقاق اسم خاندش أو خانديش من " كانهاديش "، أرض الن "

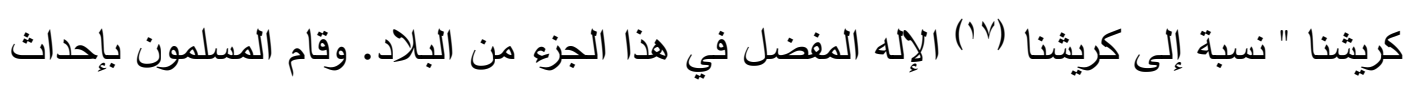

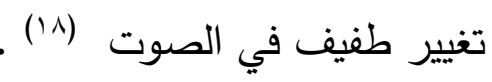
ولكن اكثر الآراء تميل إلى أن معنى خاندش أو خانديش بمعنى " أرض الخانات "

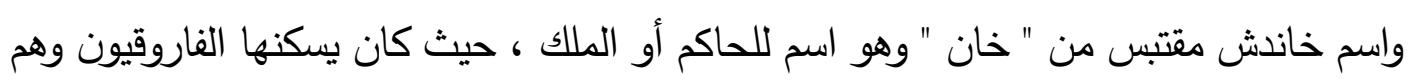

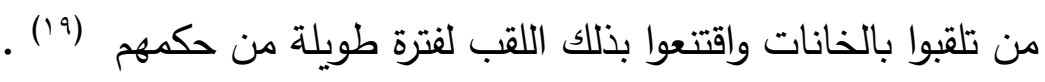

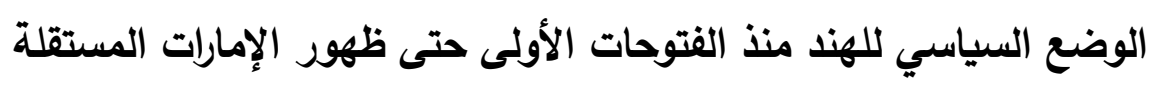

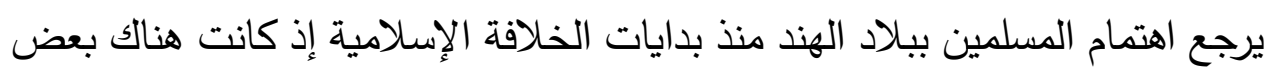
المحاولات من قبل الخلفاء الراشدين أو ولاتهم لكثف أسرار تلك البلاد ومحاولة فتحها ، أما في لهات العصر الأموي فقد كانت أول حملة نظامية حقيقية في عهد الخليفة الوليد بن عبدالملك (

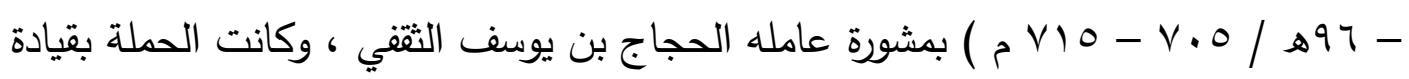

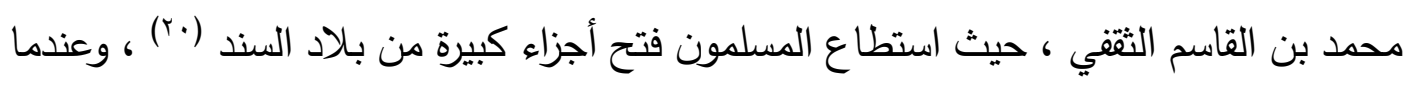

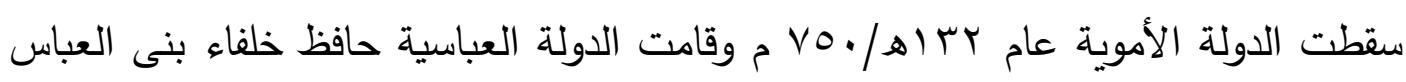
على الفتوحات التي تمت على أيدى الأموين في بلاد الهند ، وقاموا بمحاولات لتوسيع تلك 
الفتوحات أما الفتوحات الكبرى في الهند فكانت في عهد الدولة الغزنوية ، حيث قام الغزنويون

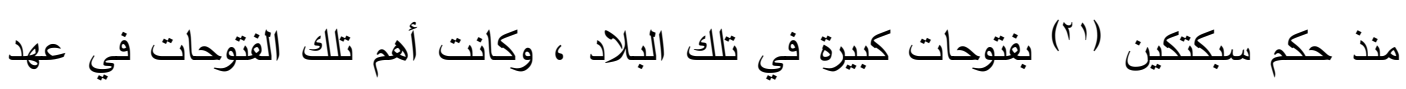

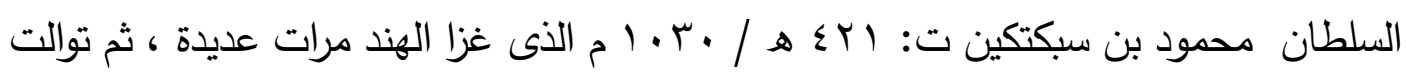

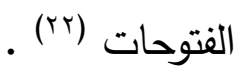
كانت ولاية الغور (rr) الافغانية قد انضدت إلى الدولة الغزنوية في عهد السلطان

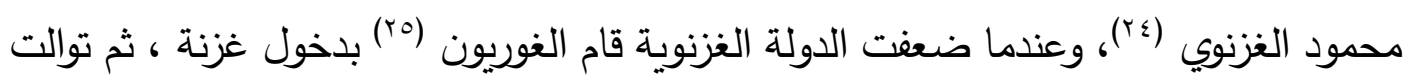

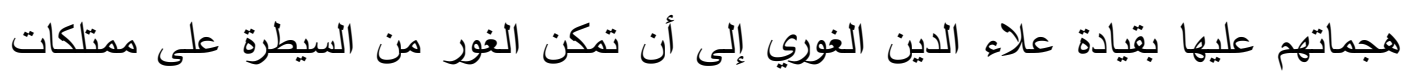

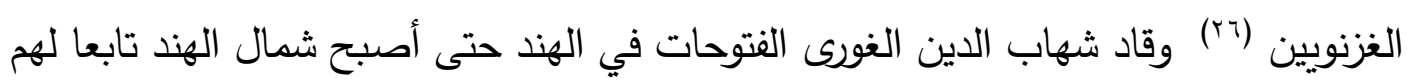

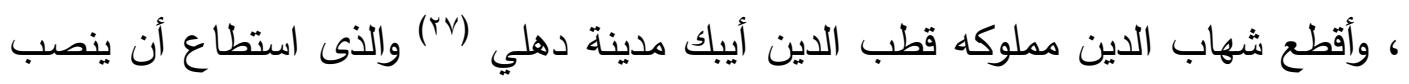

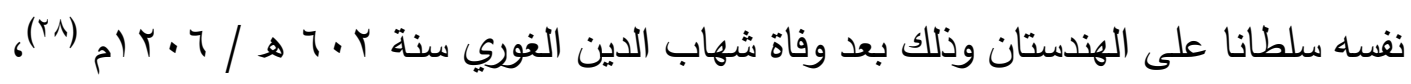

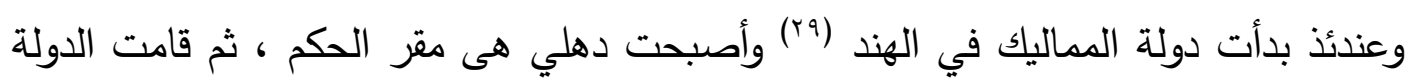

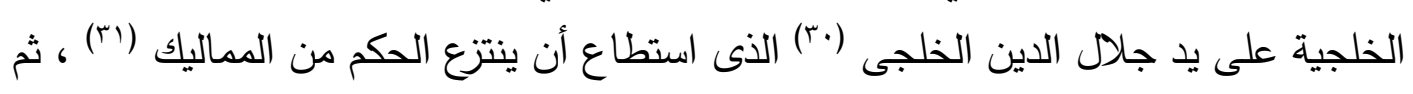

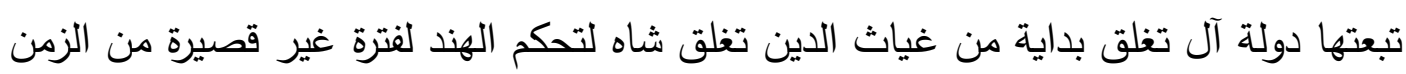

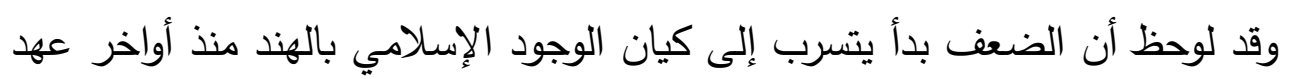

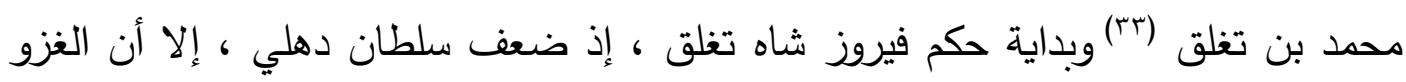

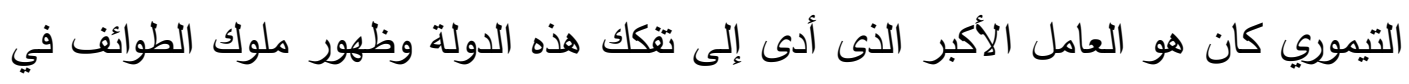

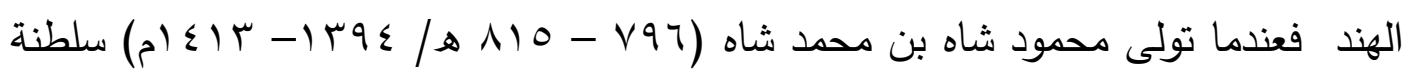

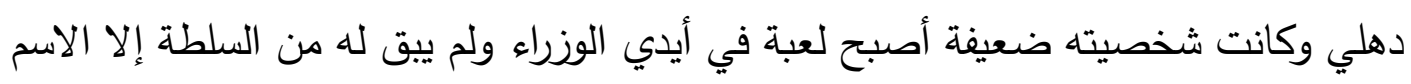

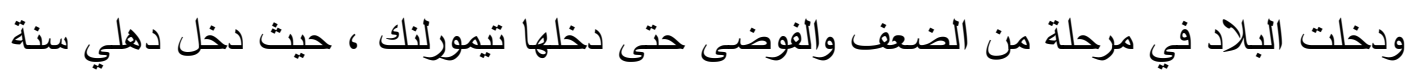

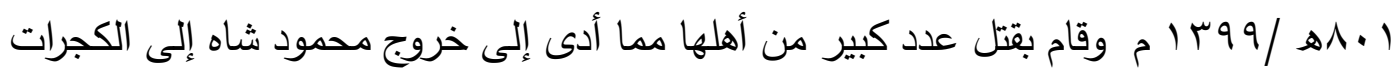

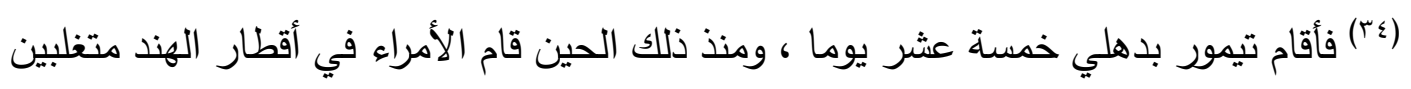

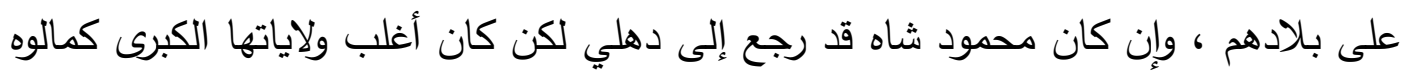

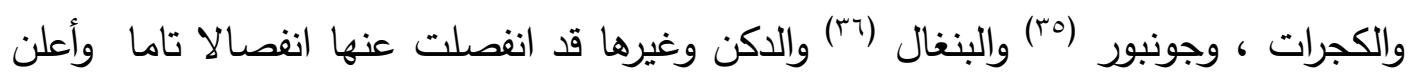

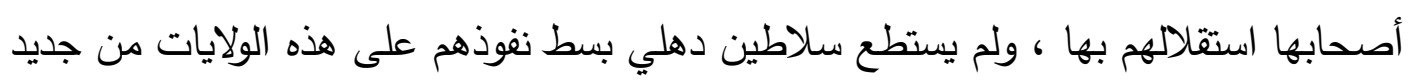

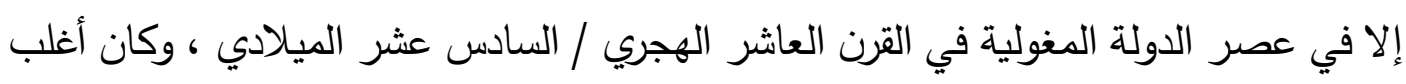


سلاطين هذه الولايات المستقلة عن دهلي قد عملوا على توسيع رقعة ملكهم والدفاع عنها والنهضة بها (rv). وكان من ضمن الإمارات التي استقلت عن سلطان دهلي هي إمارة خاندش التي استقلت على

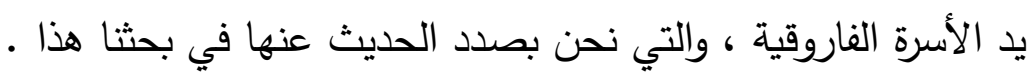
المحور الأول : الفاروقيون في خاندش .. النشأة وتوطيد النفوذ والتوسعات أول من نال الإمارة بخاندش من الفاروقيين هو " ملك أحمد " المشهور بـ " ملك راجه

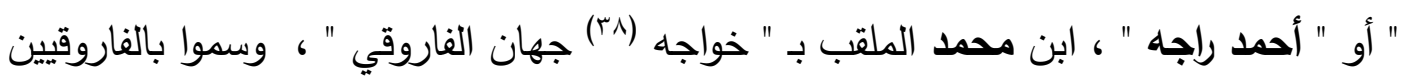
لأنهم يدعوا نسبهح إلى الخليفة عمر بن الخطاب " الفاروق " رضى الله عنه ، و كان أسلاف ملك راجه من بين الأمراء أصحاب المناصب الكبيرة بدهلي في عهد علاء الدين الخلجي (39) ومحمد بن تغلق ، وكان والد ملك راجه " محمد فاروقي " صاحب مكانه كبيرة في دهلي ،

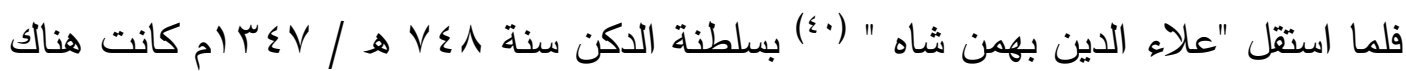
صداقة بينه وبين محمد فاروقي فزوجه أخته واستوزره ، ولقبه " خواجه جهان " ، فأنجب خواجه

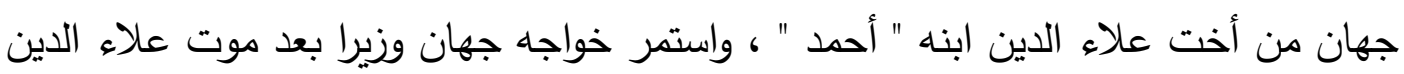
بهمن وبعد وفاته أصبح أبنه أحمد وزيرا أيضا عند البهنيين لكن حدث خلاء خلاف بينه وبينهخ

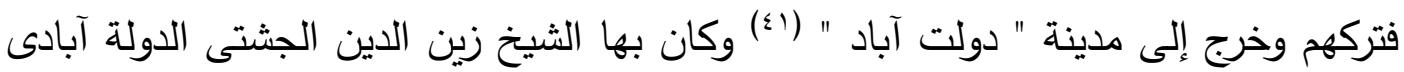
(r) ، فتوجه إليه أحمد ، وعندما دخل عليه قال له الثيخ مرحبا راجه أحمد ، وراجه معناها

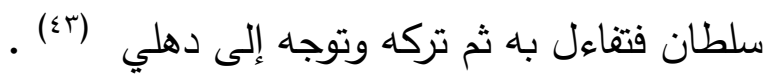
ورث ملك راجا عن والده ميراث وممتلكات صغيرة ، فقام بالخدمة كجندي عادى في

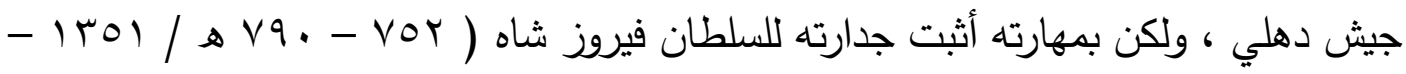

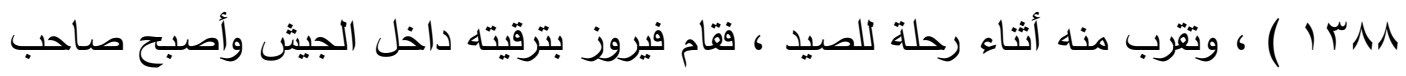
مكانة كبيرة ، حتى أصبح حارساً شخصياً للسلطان ، وكان دائماً برفقته أثناء رحلاته ، ووجهه

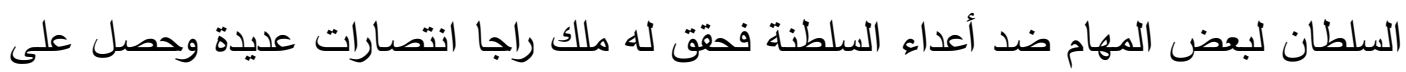
غنائم كثيرة (๕) وهنا كافأه السلطان ورفعه إلى رتبة قائد على ثلاثة آلاف فارس ، وفي غضون سنوات قليلة كان على رأس اثني عشر ألف فارس بسبب الخدمات التي قدمها للسلطان فيروز

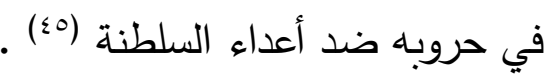




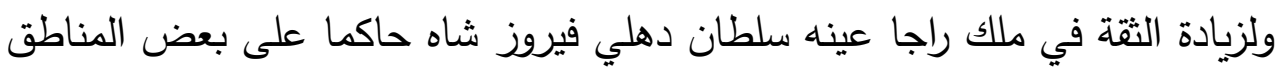

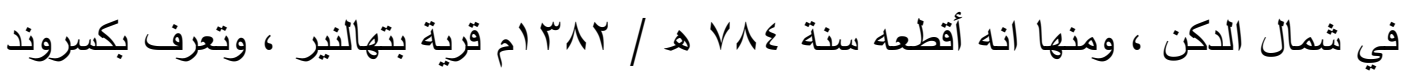

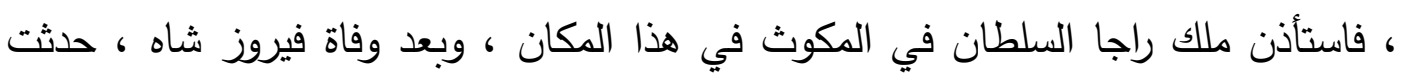

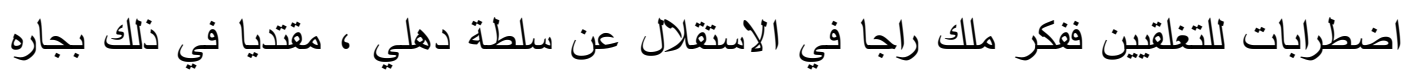

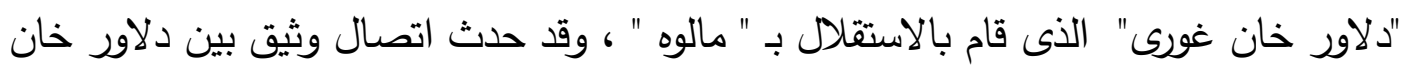

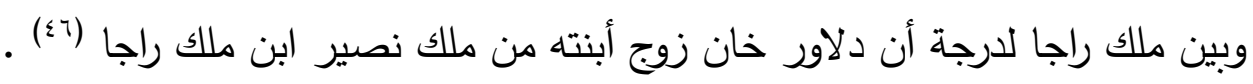

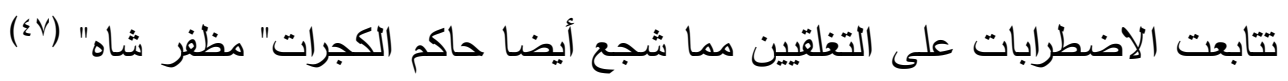

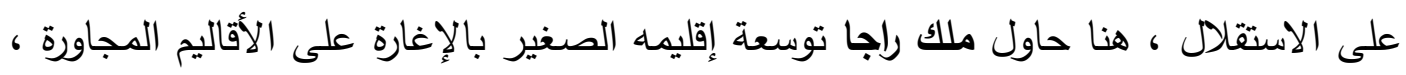

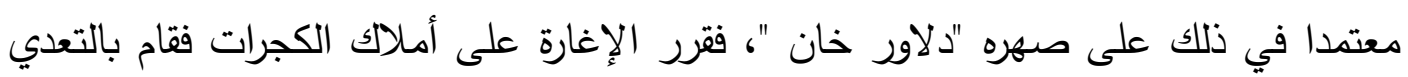

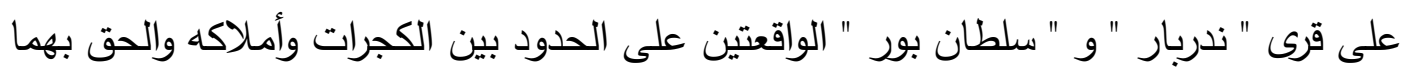

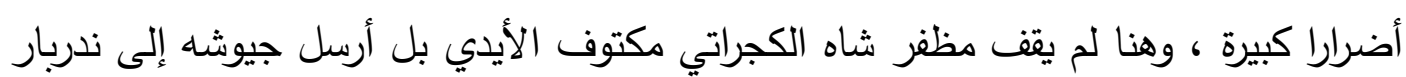

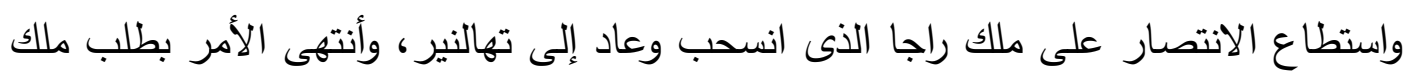

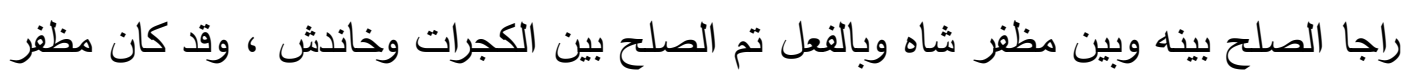

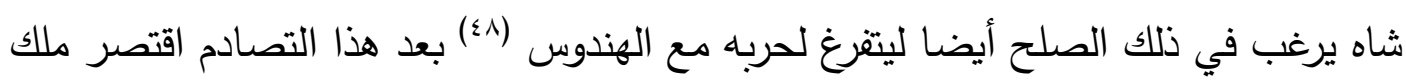

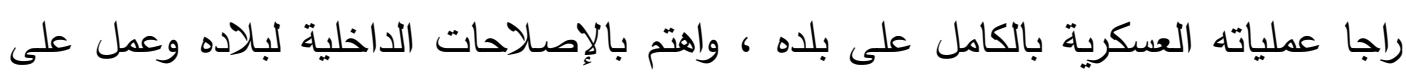

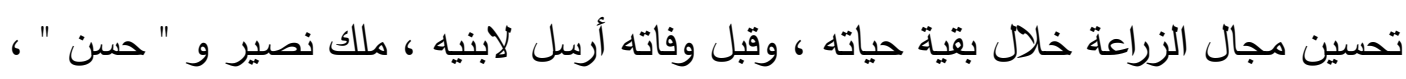

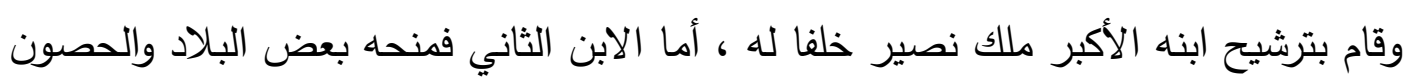

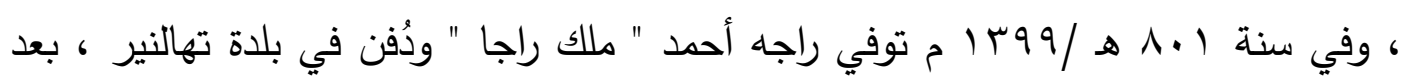

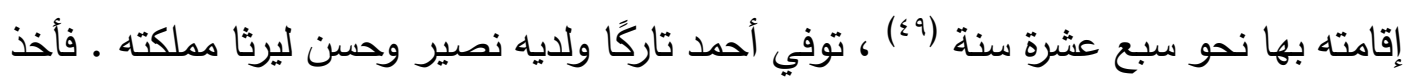
نصير المناطق الثرقية وحسن المناطق الغربية من الإقليم (•) .

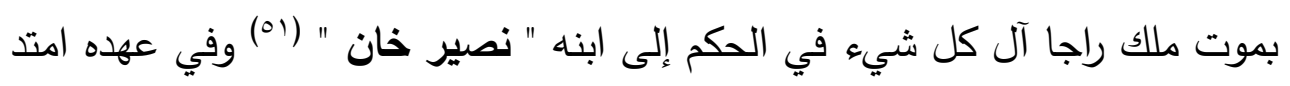

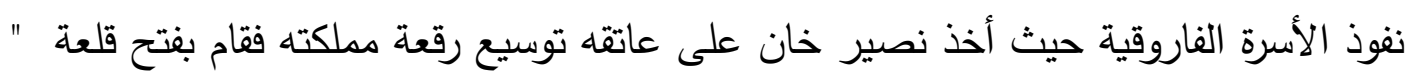

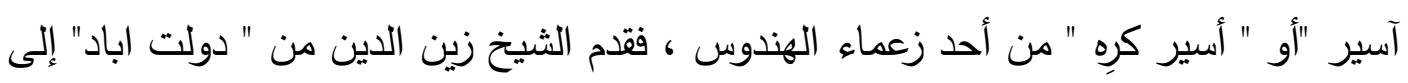

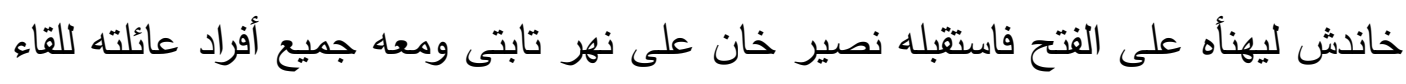

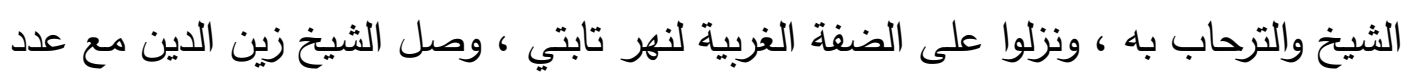

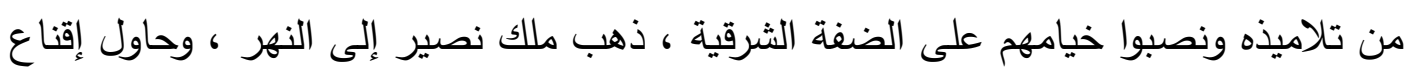


الثيخ بالعودة معه إلى آسير ؛ لكنه رفض القيام بذلك وقال إنه لم يكن لديه إذن لعبور نهر

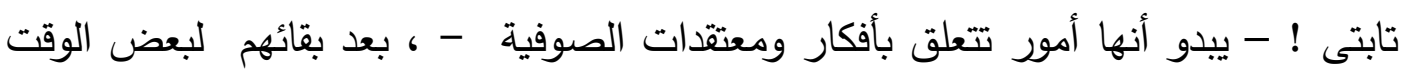
على الضفتين الغربية والشرقية ، أراد الشيخ الانصراف ؛ بافئ لكن ملك نصير توسل إليه أن يتنازل

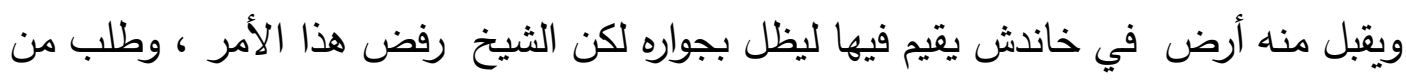

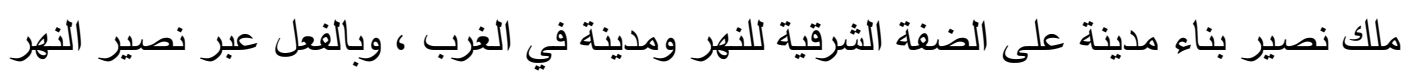

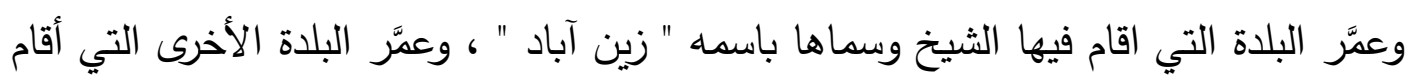

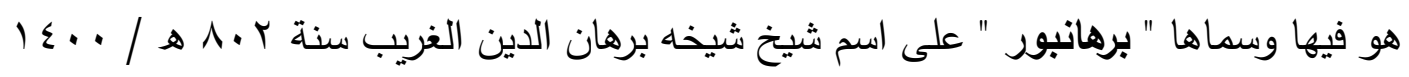
م والتي أصبحت منذ ذلك الحين حاضرة لسلطنة خاندش ، وقام بعدها بعدة فتوحات منها فتح

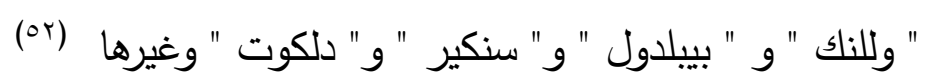
ويلاحظ أن تطلعات نصير خان كانت كبيرة لدرجة أنه بعدما سيطر على " آسير " أراد أن

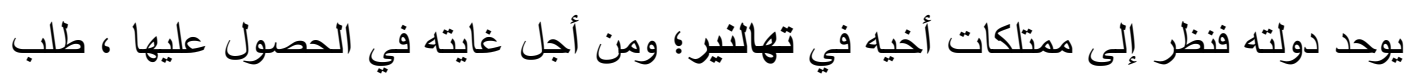

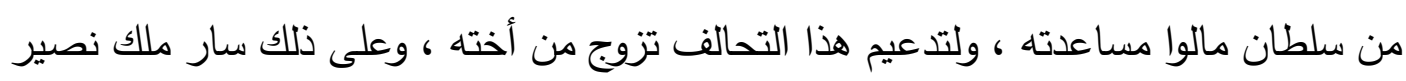

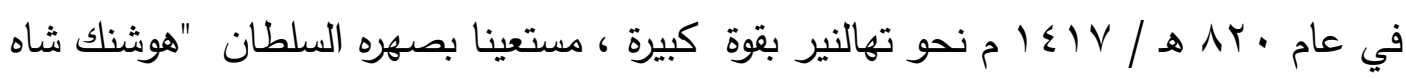

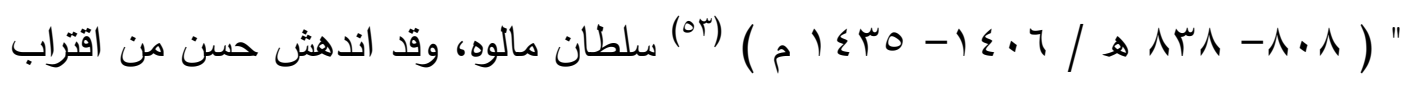

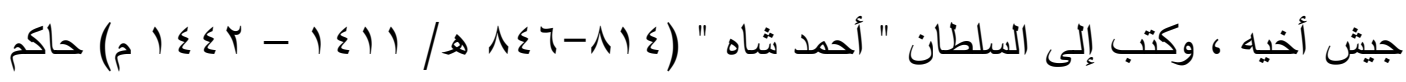
الكجرات طالبا منه المساعدة ـ تطورت الأحداث وقام السلطان " هوشنك شاه " بإرسال ابنه

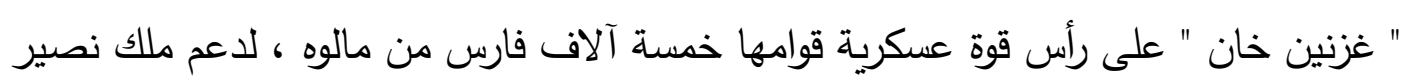
؛ وبجهودهم المشتركة ، سقط حصن تهالنير في وقت قصير بالمكر والحيلة ، وقام بأسر أخيه حسن وإرساله إلى حصن آسير ، وبعد الاستلاء على تهالنير ، تم الاتفاق بين القوات المتحالفة

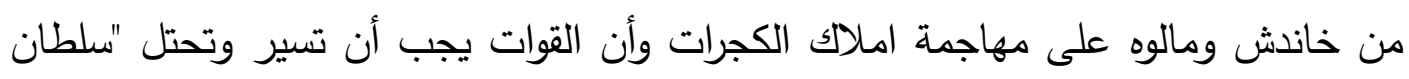
بور " باسم ملك مالوه ؛ ولهذا الغرض قاموا بمهاجمة سلطان بور ، و " ندربار " وقاموا باعمال

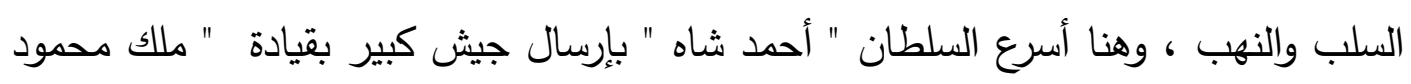

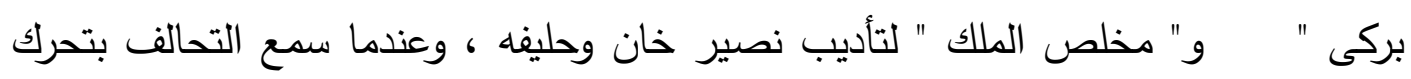
جيوش الكجرات ، هرب غزنين خان إلى ولايته ، وانسحب ملك نصير إلى تهالنير وتحصن

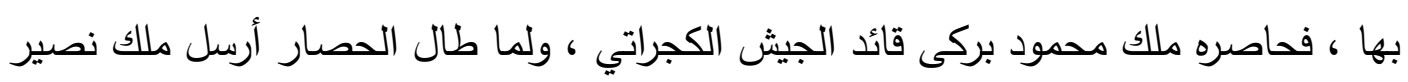

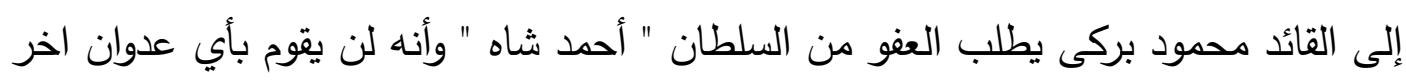


على الكجرات في المستقبل ، وبالفعل كتب السلطان أحمد شاه مرسوما بالعفو عن جرائمه ، وخلع عليه ومنحه لقب " خان " ومنذ ذلك الوقت أصبح من حلفائه (؛؛) . بعد العفو الذى قدمه السلطان " أحمد شاه " رجع إلى سلطنته وأخذ معه حسن بن ملك راجا الفاروقي الذى قربه منه ، ولزيادة أواصر الصلة بين الكجرات وخاندش زوج أحمد شاه " حسن خان " من إحدى قريباته فولدت له " غزنين خان " الذى تزوج من ابنة السلطان " أحمد الداديه

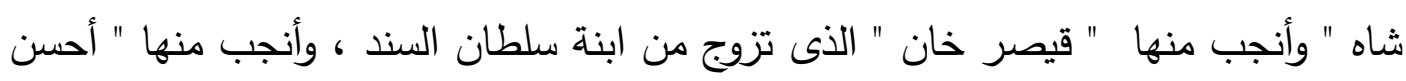

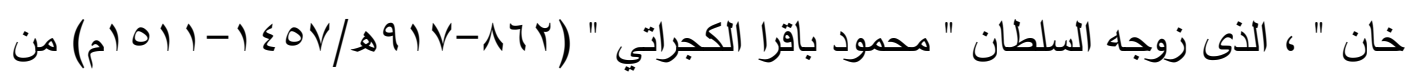

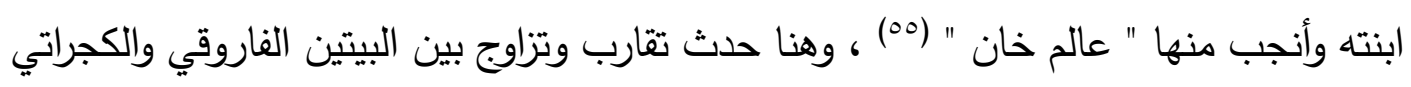

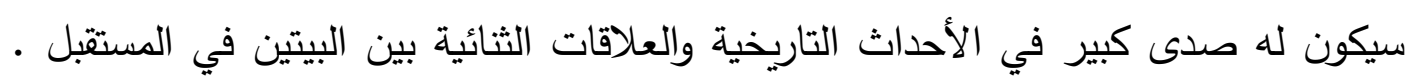

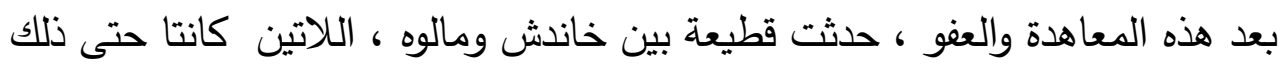
الوقت حليفتين ، حيث استاء نصير خان من فشل السلطان "هوشنك شاه " سلطان مالوه في دعمه بشكل كاف ضد أحمد شاه وانقطعت العلاقات الودية بين الطرفين (ro ) .

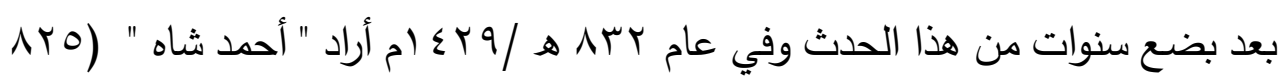

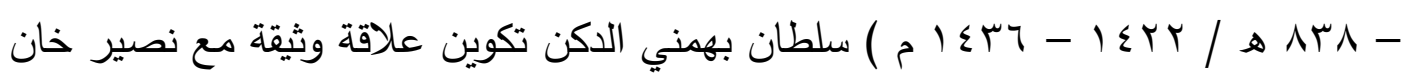

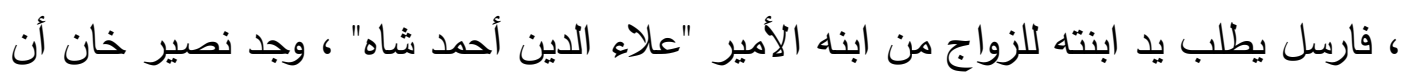

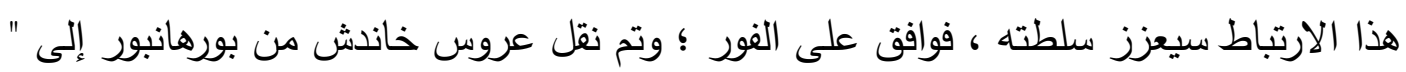

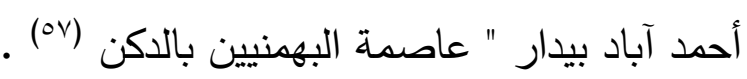

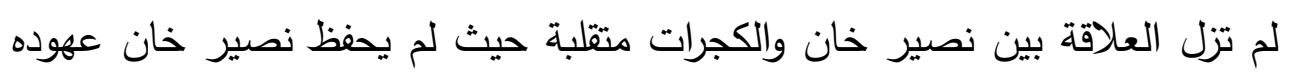

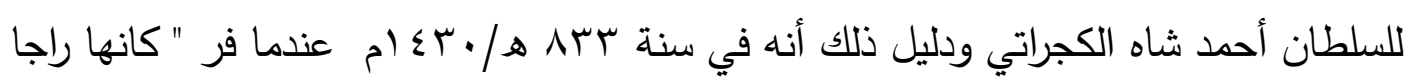

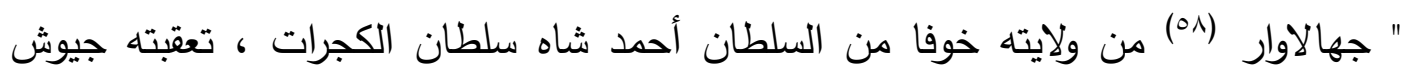
الكجرات حتى وصل " كانها راجه " إلى خاندش ولجأ إلى نصير خان طالبا منه الأمان والحماية

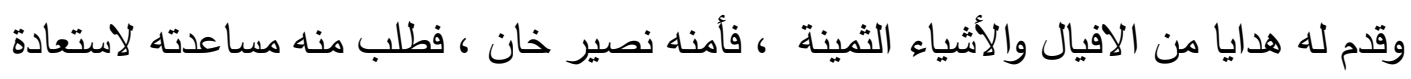

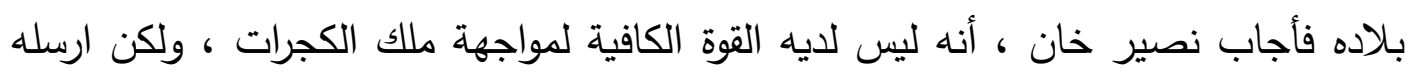

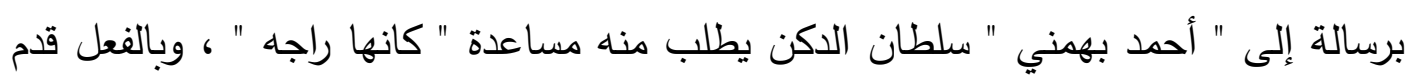

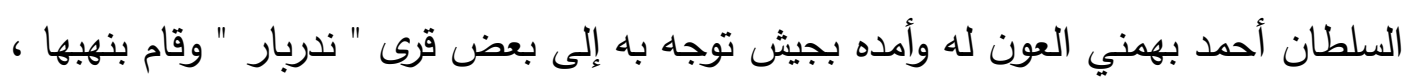

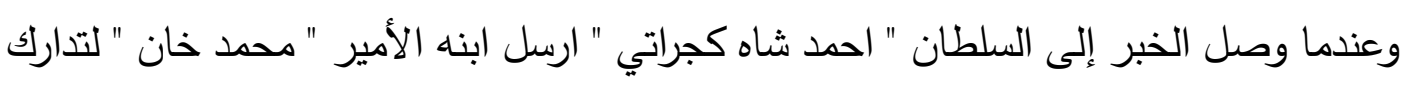


الأمر ، وبالفعل اشتبك جيش الأمير محمد خان بجيش الدكن ، وأنتصر محمد خان وقَتل وأسر كثير من الدكنيين ، فتفرق جيشهم وذهبوا إلى " دولت آباد " ، وعندما وصل الخبر إلى السلطان

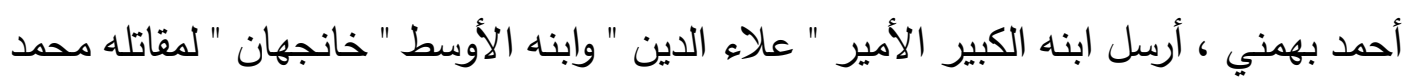

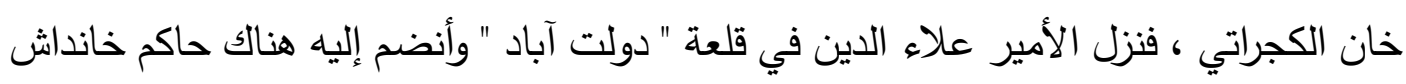
نصير خان وكذلك قوات " كانها راجه " فقوى أمرهم ، فتوجه محمد خان إلى دولت آباد آناد لمواجهتهم وبالفعل استطاع النصر عليهم جميعا ، وفر الجميع حيث لجأ الأمير "علاء الدين "

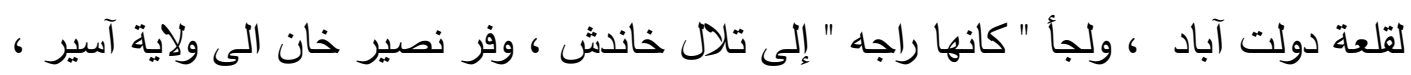

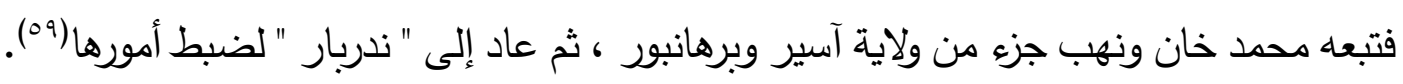

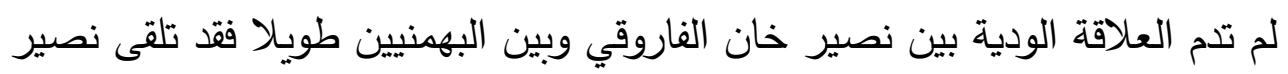

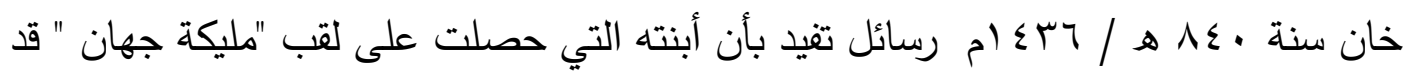

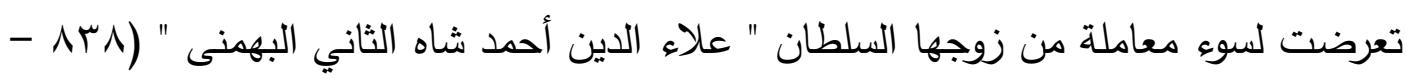

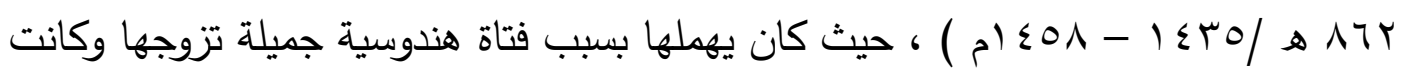
تدعى " زيبا شاهرا " ، فقرر نصير خان الانتقام لابنته ، وتحقيق بعض المكاسب ، ف فقام

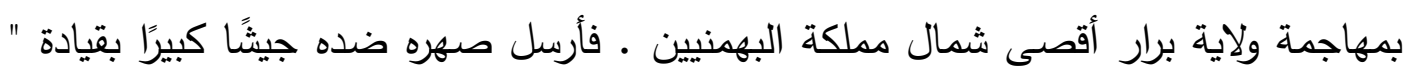

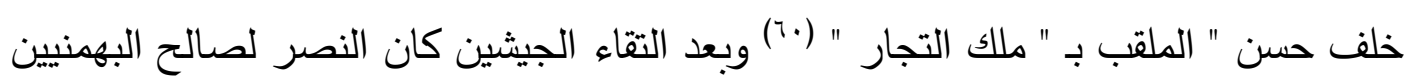
، حاول نصير الاستعانه بسلاطين الكجرات ومالوه ، لكن ملك التجار قرر إنهاء الأمر قبل التبل

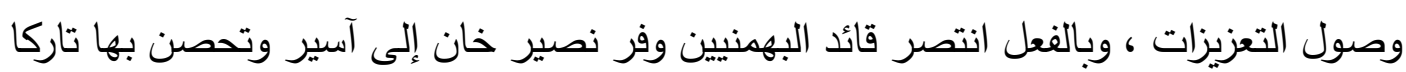

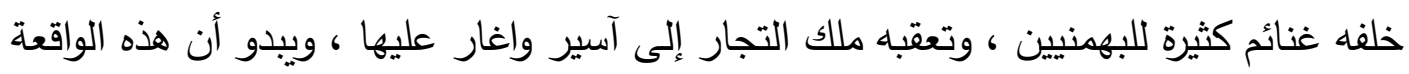

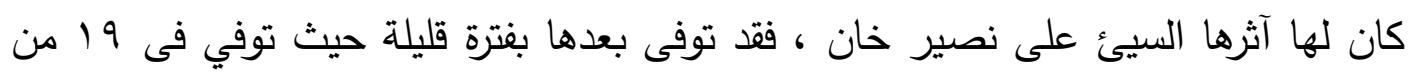

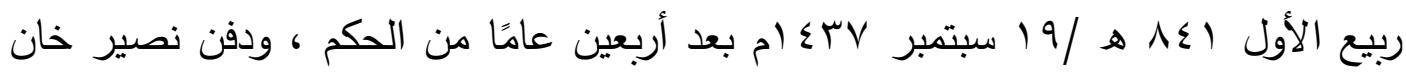

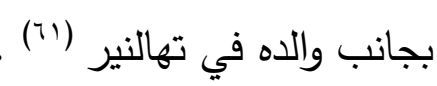

\section{المحور الثاني : سياسة الفاروقين وعلاقاتهم الخارحية مع الإمارات المستقلة في الهند} بعد أن تحدثنا عن شخصية كل من ملك راجا ونصير خان وكيف استطاعا أن يوطلا نفوذ الفاروقيين في خاندش وتوسيع نطاق الإمارة نتطرق الآن إلى الحديث عن باقي أمراء البيت

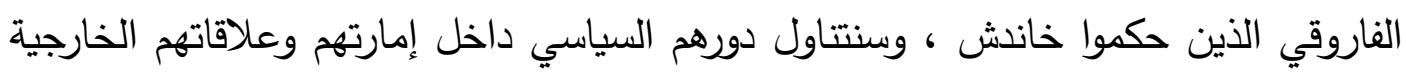
مع الإمارات المستقلة بالهند ، حتى سقوط الإمارة. 
خلف " ميران عادل خان " والده في حكم خاند ، وعند تعيينه كتب على الفور رسائل ملحة إلى ملوك الكجرات ومالوه لمساعدته في رفع الحصار الذى ضربه " ملك التجار " قائد البهمنيين على بعض أملاك خاندش ، وبالفعل عندما تحرك الجيش الكجراتي ووصل إلى سلطان بور ، فلك ملك التجار الحصار ورجع إلى الدكن ، بعد ذلك حكم عادل خان قرابة

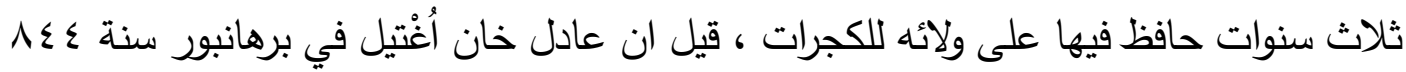
هـ / إ أ م ، ودفن في تهالنير بجانب والده ولكن لا توجد أي معلومات أكيده حول طريقة

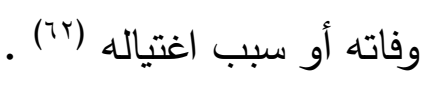

بعد وفاة عادل خان تولى ابنه " مبارك خان " ، وعلى الرغم من طول فترة حكمه لكن

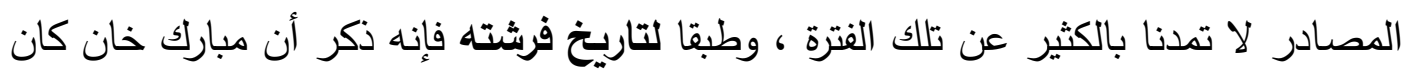
يعيش في سلام ولم يقم بأي فتوحات خارجية ، وكان اهتمامه منصبا على الإدارة المدنية للبلاد

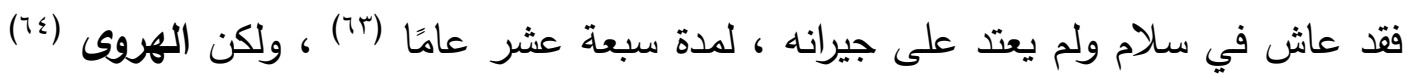

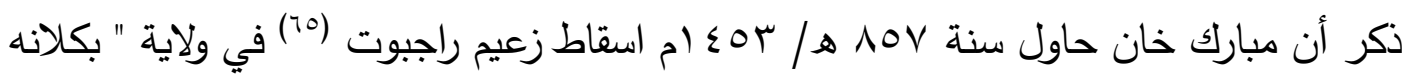

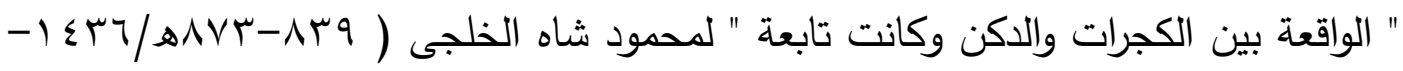

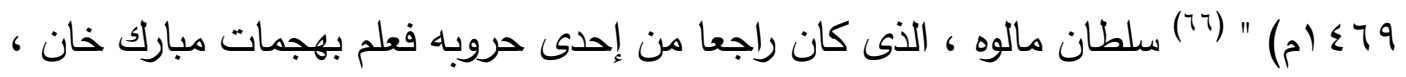

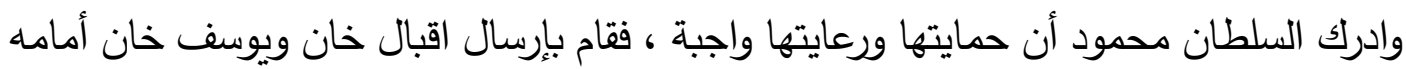
على الفور على رأس جيش ، وجاء مبارك خان بجيش جرار والتقى الجيشان وبعد القتال هُرِمَ مبارك خان وفر وانتهب السلطان محمود بعض قرى بلاد آسير وعاد الى شادي آباد .

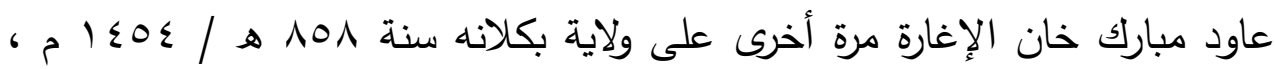
فوصل الخبر إلى السلطان محمود الخلجى سلطان مالوه بأن ابن راى بابو راجه حاكم ولاية بكلانه يريد المجيء إليه وأن مبارك خان حاكم خاندش دخل ولايته وخربها ، ومنعه من القدوم

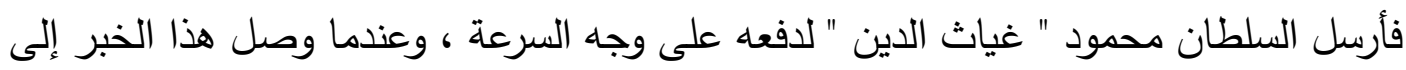

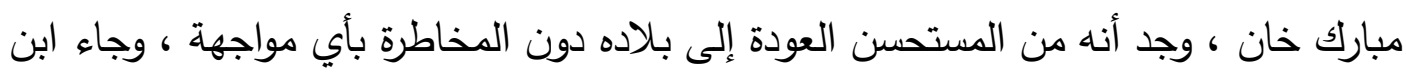
بابو بهدايا كثيرة إلى السلطان محمود ، ونال الإنعام وسمح له بالعودة إلى ولايته ، بعد ذلك بلك

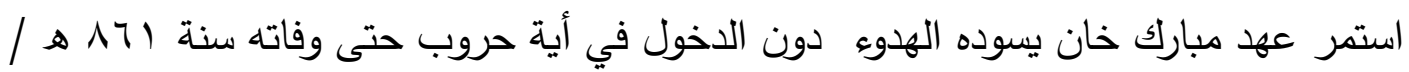
(TV) ${ }^{(T)} 1 \leq 0 V$ 
بعد وفاة مبارك خان ، خلفه ابنه الأكبر " عادل خان الثاني " وأصبحت خانش في

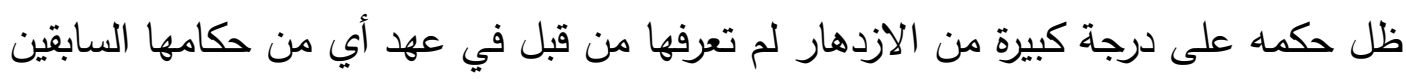

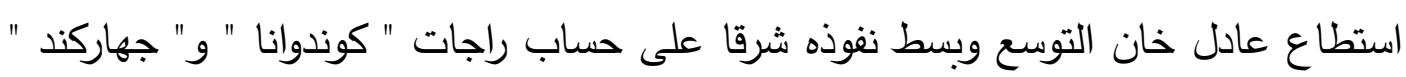

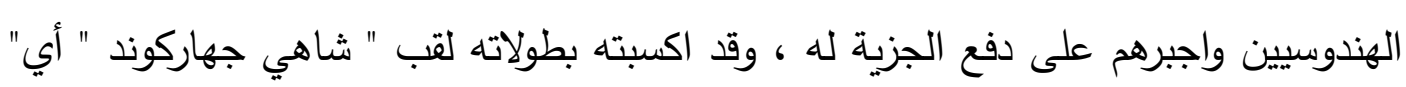
ملك الغابة "، وقد زاد عادل خان من تحصينات آسير بثكل كبير ، وطور من مدينة برهانبور

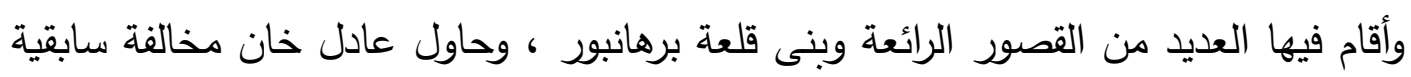

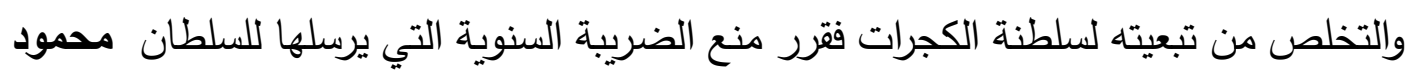

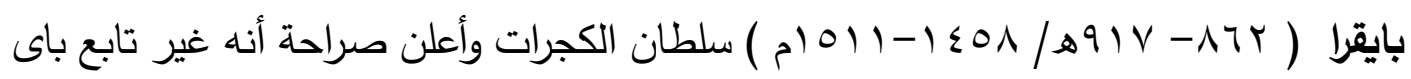

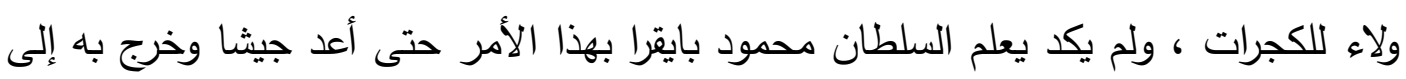

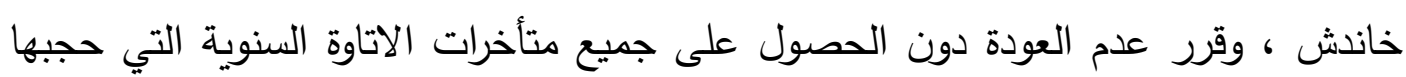

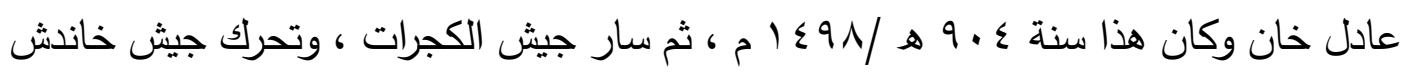

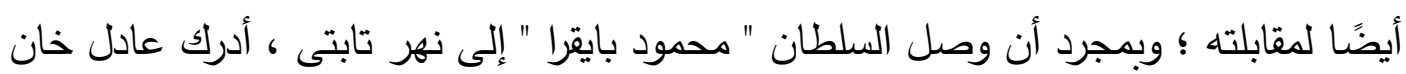

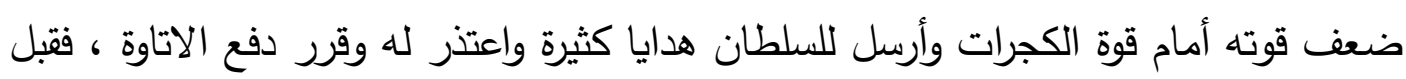

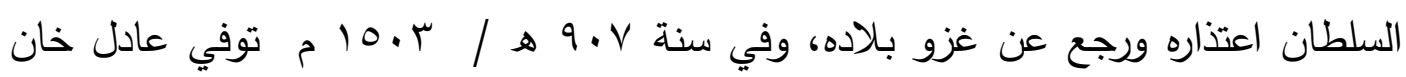

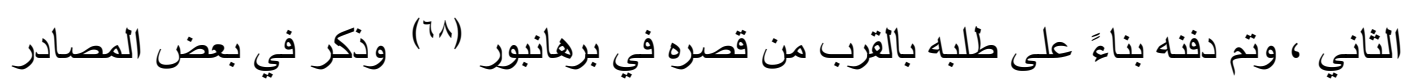

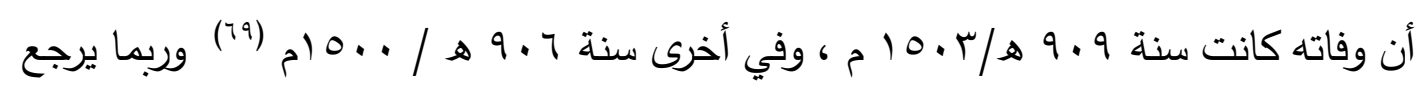

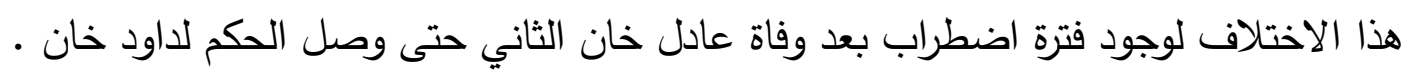

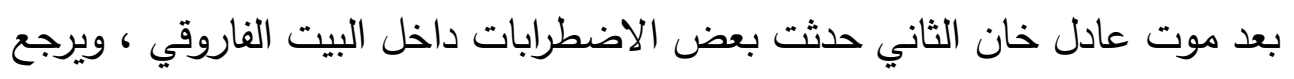

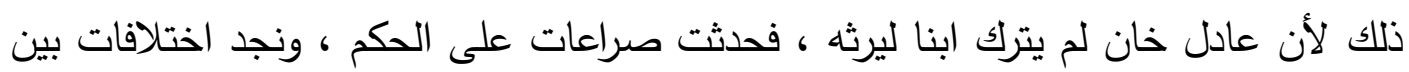

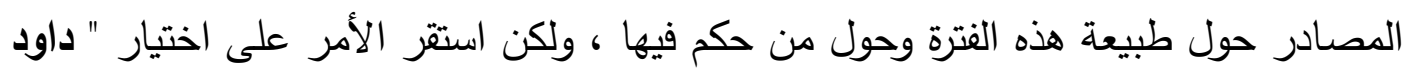

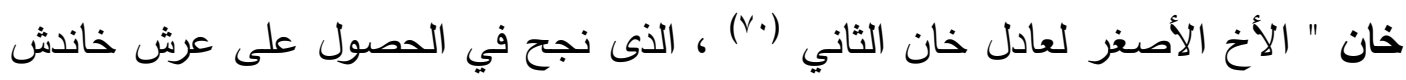

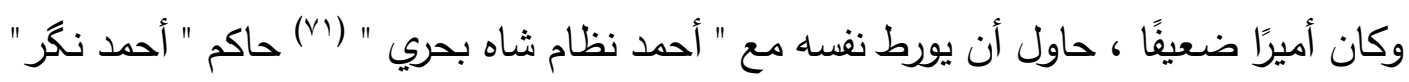

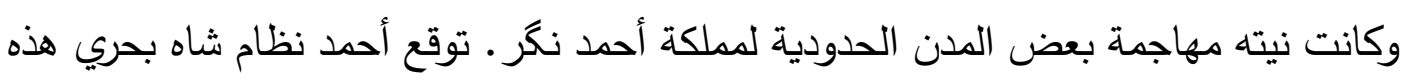

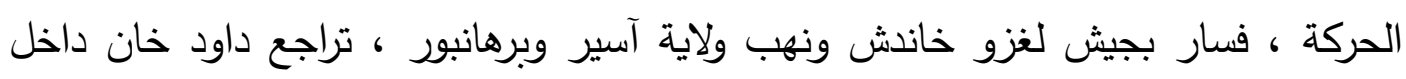

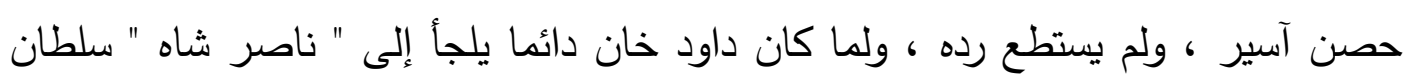

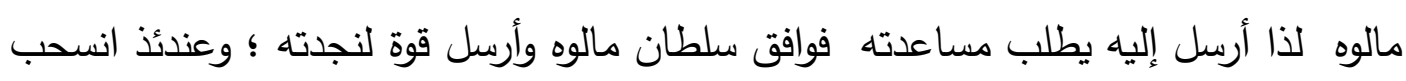


نظام شاه بحري لعدم رغبته في التورط في حرب مع مالوه ، وقرر العودة الى بلاده ، لكن داود

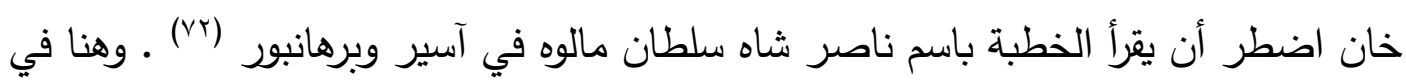

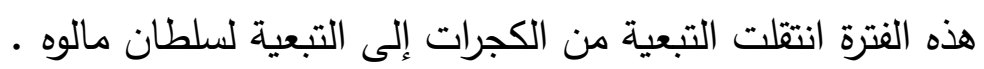

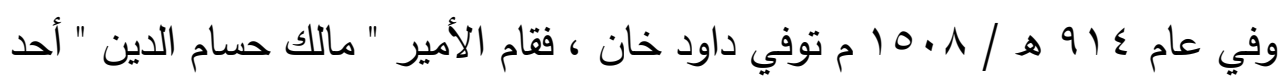

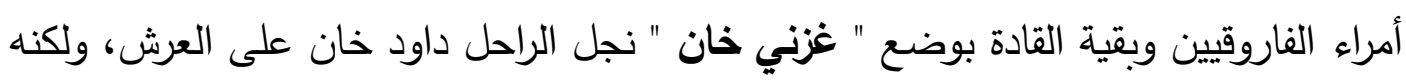
مات مسموما بعد حكم دام عشرة أيام وقيل يومين وفي هذه الفترة حدثت اضطرابات كثيرة داخل البيت الفاروقي وانقسم الأمراء حول من يرغبون في تعيينه حاكما للسلطنة ، وأدى ذلك للتدخلات الخارجية التي ارادت هي الأخرى فرض نفوذها وتعيين من ترغب فيه تحقيقا لمصالحها ، وتلك

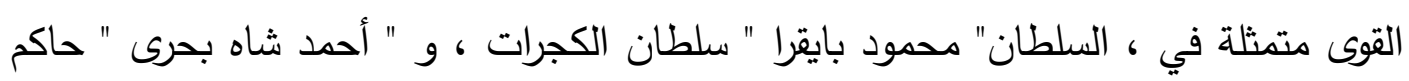

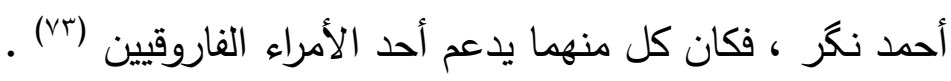

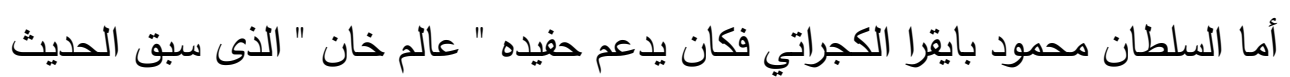
عنه وكان بسبب المصاهرات التي حدثت بين البيتين الفاروقى والكجراتي ، فهو " عالم خان

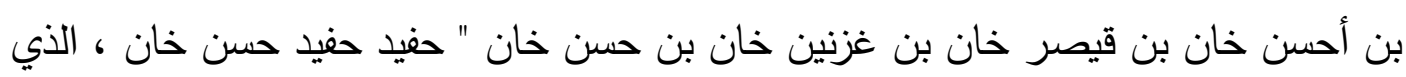

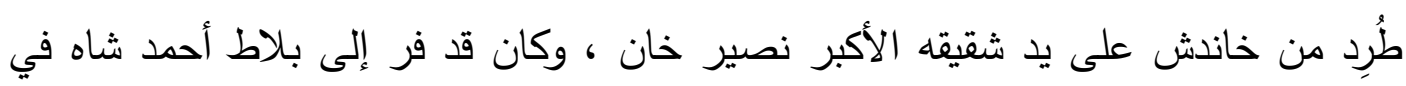
سلطنة الكجرات ، وسبق تفصيل هذا الأمر وتلك المصاهرات التي نتج عنها " عالم خان " وفي بهي نفس الوقت كان ابن بنت السلطان محمود الكجراتي الذى وافق بعد طلب ابنته على تولية حفيده

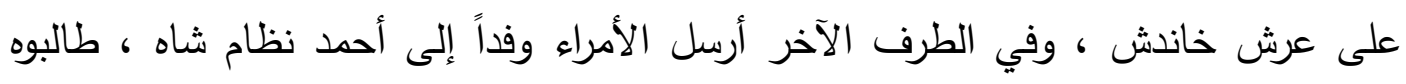

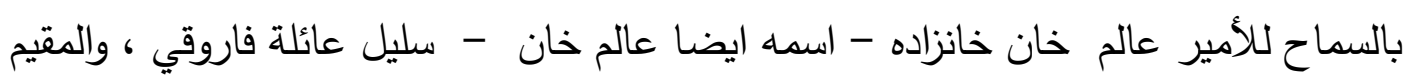
آنذالك عند أحمد نظام شاه في أحمد نكر بتولي أمر خاندش ، وعقد نظام شاه بحري و" عماد

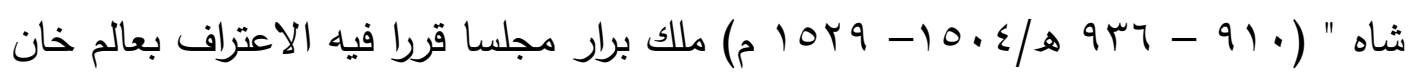
خانزاده على عرش خاندش الثاغر ، وهنا قُسمت خاندش إلى فصيلين ، أحدهما يؤيد المدعوم

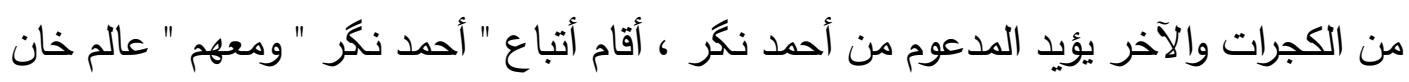

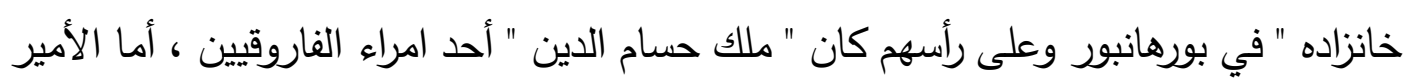
" ملك لادن خلجى " ، الذي كان يقود قلعة آسير فقد رفض الاعتراف بالخان الجان الجديد وكان

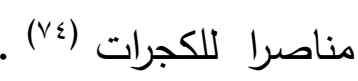


وقد أدرك السلطان محمود بايقرا الكجراتي أن خاندش كانت على وشك الانخراط في

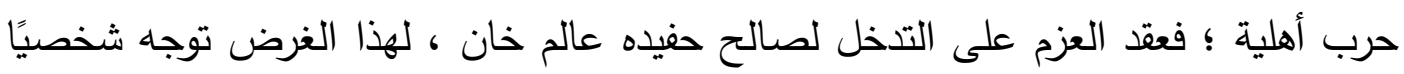

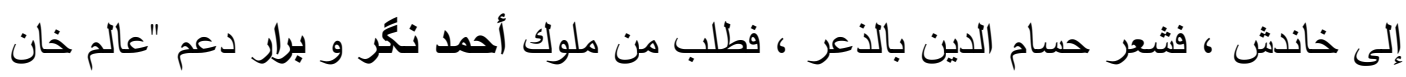

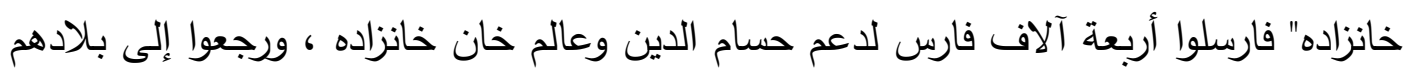

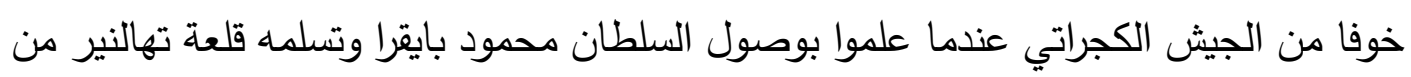

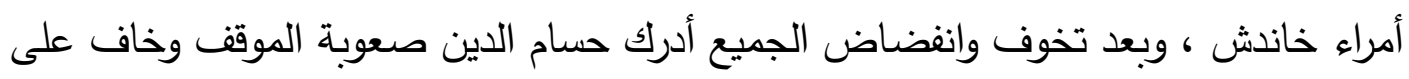

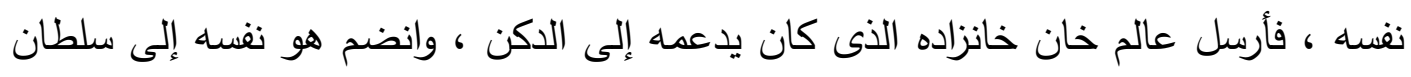

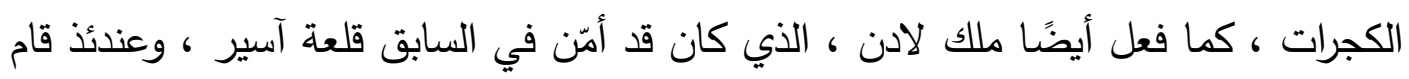

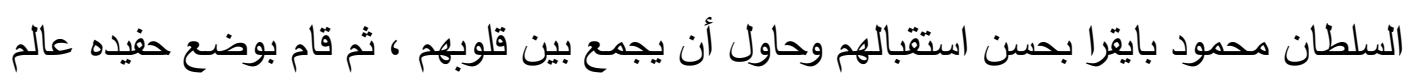

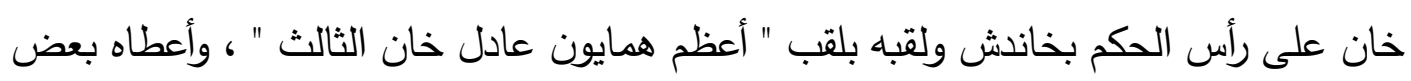

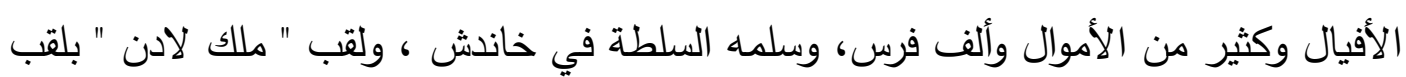

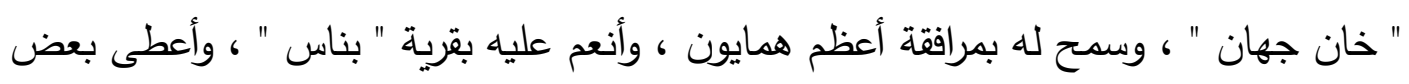

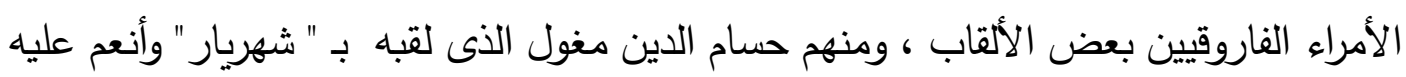

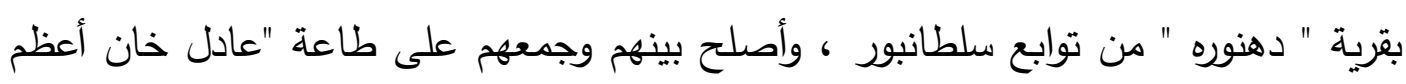

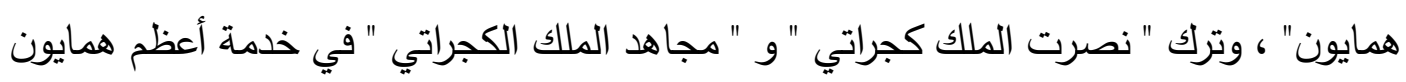

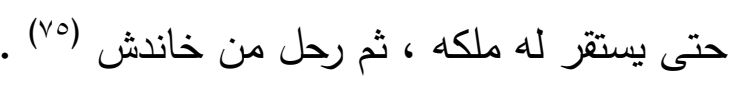

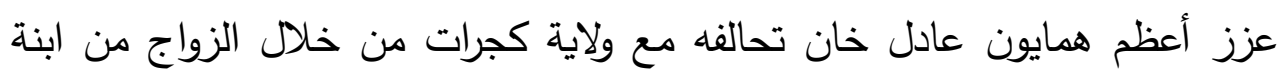

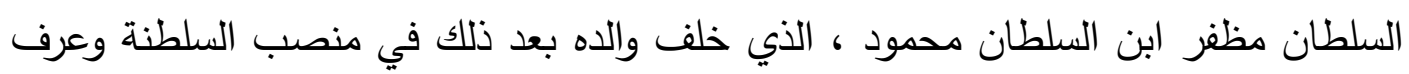

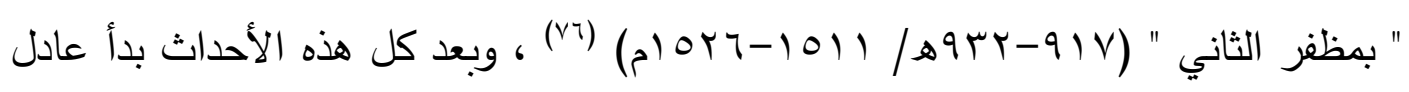

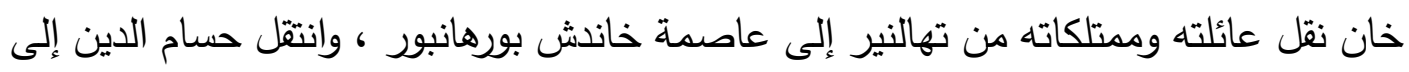

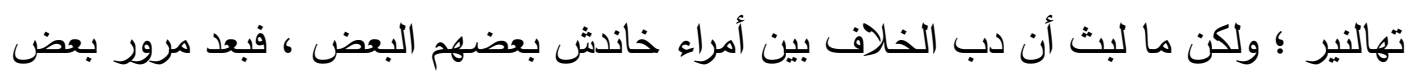

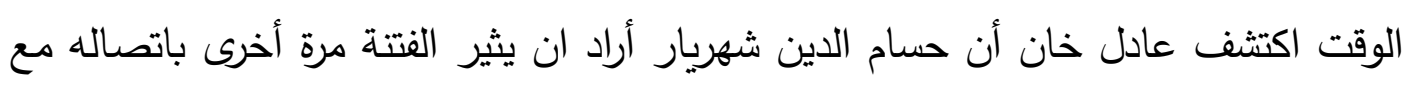

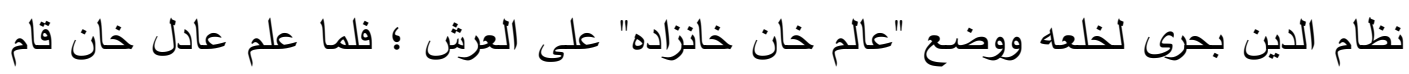

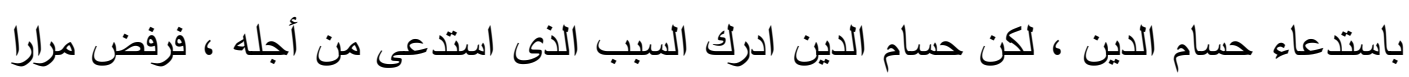

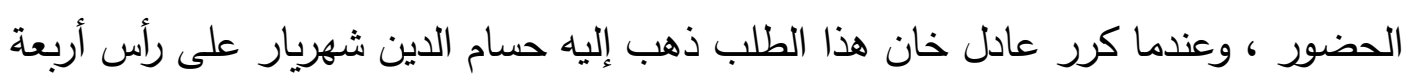

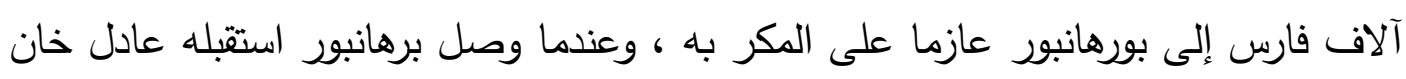


بفرسانه من الكجرات ، وحمله إلى منزله واكرمه ، وسمح له بالانصراف ، وأخذ يدبر لقتله

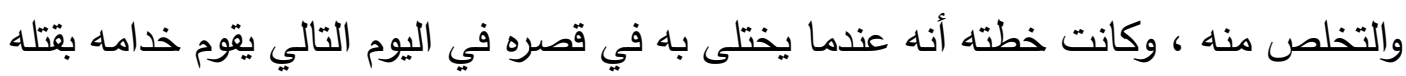

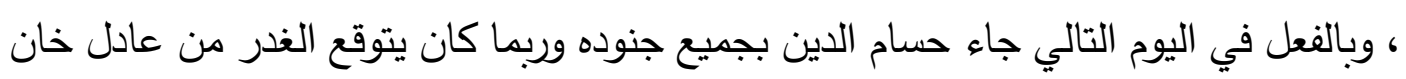

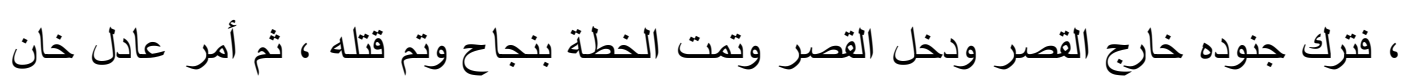

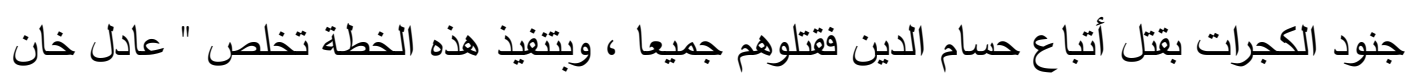
" من أحد أهم كبار المعارضين لحكمه (vv) . لم ينته الأمر عند هذا الحد ولكن بعد فترة وجيزة زار " عادل خان " قلعة آسير وعلم أن " شير خان " و " سيف خان " المسيطران على القلعة ينويان الغدر به ، وعلم أنهما أرسلا

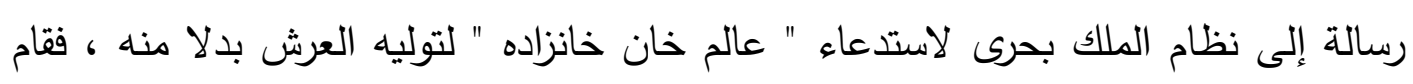

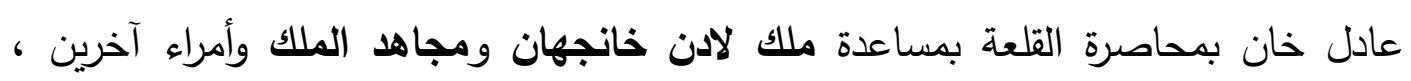
وبالفعل جاء نظام الملك بحرى بجيشه برفقة عالم خان خانزاده ووصل إلى حدود خاندش ، فأرسل عادل خان على الفور رسولا إلى مظفر شاه الثاني الكجراتي صهره ، يشرح له بالتفصيل

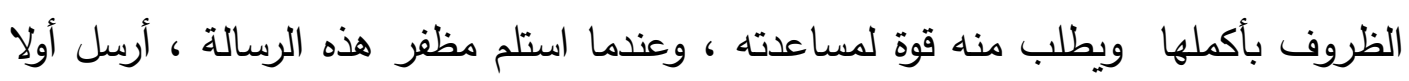

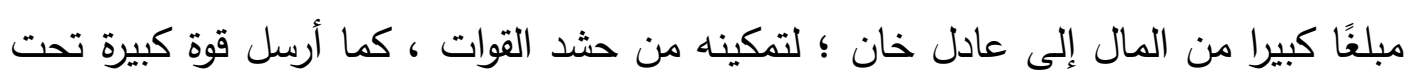
قيادة " دلاور خان " و"صفدور خان " لمساعدته ، وكتب له " فليسترح خاطر ابنى في كل ما لها

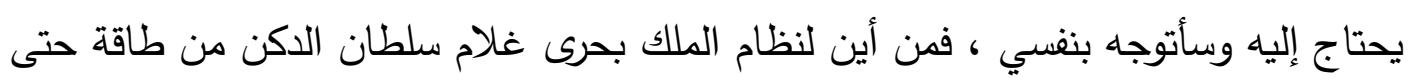

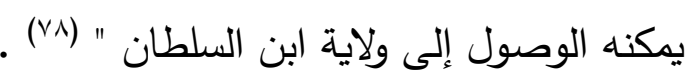
ظهر من رسالة مظفر شاه الكجراتي مدى الدعم الكبير الذى سيقدمه لعادل خان همايون وكان فيها ما يريح قلبه ، وعندئذ أرسل نظام الملك بحرى رساله لمظفر شاه يطلب منه ماته اعطاء جزء من ولاية آسير وبرهانبور لعالم خان خانزاده ، فاستدعى مظفر شاه رسل نظام الملك وخاطبهم بلهجة حادة ردا على هذا الطلب وأظهر تصميمه على دعم عادل خان همايون ، ادرك أحمد نظام شاه أنه من الحكمة التراجع خوفا من مظفر شاه الكجراتي ، وقيل إنه عندما وصلت قوات الكجرات إلى ندربار سمعوا بخبر موت نظام الملك فارسلوا هذا الخبر للسلطان مظفر شاه أما شير خان وسيف خان عندما علما بالموقف شعرا بسوء عاقبتهما فطلبا الأمان ، فأمنهما عادل خان وسامحهما ، أما جيش الكجرات فقد استخدمه عادل خان لتأديب ولجباية

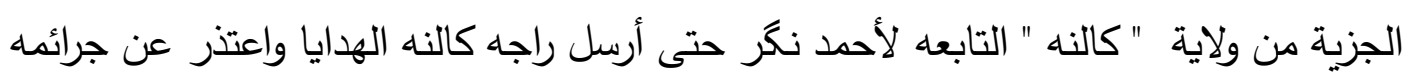


، وبعد ذلك سمح عادل خان لأمراء الكجرات الذين كانوا في خدمته بالعودة الى ديارهم بعدما استقر له الأمر وذهب هو إلى برهانبور واستقر بها (va) هناك رواية في ظفر الواله تذكر أن الذى طمع في الحكم وتواصل مع نظام الملك بحري لايفاد عالم خان خانزاده ورفعه على العرش هو " ملك لادن خانجهان " أما الرواية الثانية التي ذكرناها والتي ذكرها محمد قاسم هندوشاه في تاريخ فرشته و وافقه فيها الهروى في طبقات لترني

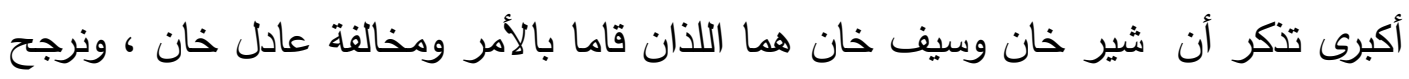
رواية محمد قاسم هندوشاه والهروى لأنها أكثر منطقية حيث كان ملك لادن خان خانجهان منذ البداية ممانعا لحكم عالم خان خانزاده ورفض تسليم قلعة آسير لله هو واتباعه ، كما كان متحالفا لهاه مع الكجرات لتسليم السلطة لعادل خان ، فكيف به بعد كل هذا وبعد إنعام السلطان الكجراتي عليه يقوم بمحاولة ارجاع عالم خان خانزاده ، فروايتا فرشته والهروي أقرب للمنطق والتصديق.

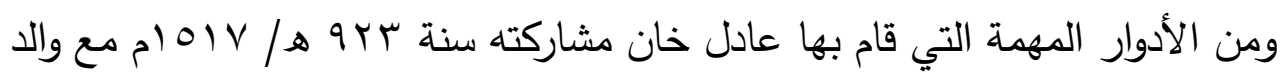

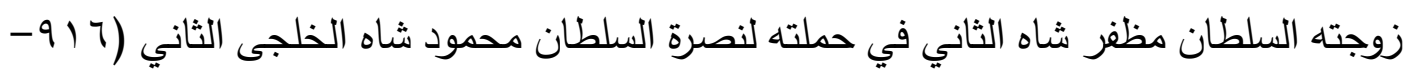
V

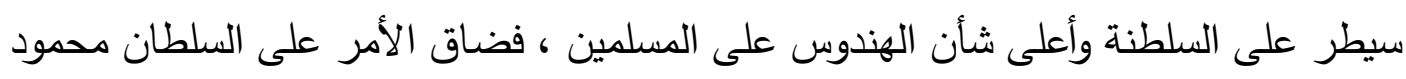
واضطر للهرب من مندو (•^) مقر حكمه ولجأ للسلطان مظفر شاه الذى خرج بنفسه لاستقباله وتوجه هو وقواده لاستعادة مندو من الهندوس وكان عادل خان من أهم المساعدين للسلطان مظفر في تلك الحروب وكان النصر حليفا لهم ، توفى عادل خان أعظم همايون في برهانبور

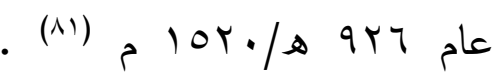
بعد وفاة عادل خان خلفه ابنه " ميران محمد خان " ابن اخت سلطان الكجرات بهادر

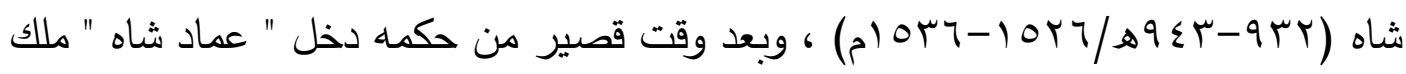

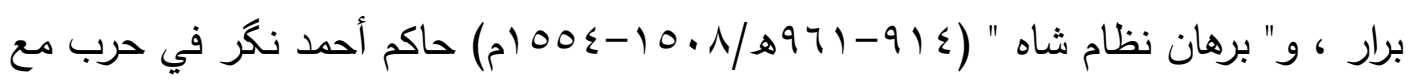
بعضهما البعض، نتج عنها فقدان ملك برار لبلده ، فلجأ إلى خاندش عند ميران محمد خان وكان بينهم مصاهرة ، فتحالفا ضد برهان نظام شاه لاسترداد برار ، ودخلا في حرب ضده لنه انتهت بهزيمة محمد خان وحاكم برار ؛ فكتب الاثنان إلى" بهادر شاه " سلطان الكجرات يطلبان تدخله في خلافاتهم مع حاكم أحمد نكر ، وارسل حاكم برار أبنه للسلطان طلبا للمساعدة ونتيجة لذلك قام بهادر شاه بالتدخل والسعي للتوسط من أجل حل سلمى للأمر ، وافق بورهان نظام شاه 
على حل ودي للأمور بصورة مؤقته ، من أجل ترضية حاكم الكجرات وخوفا منه ، ولكن بعد

فترة وجيزة عاود برهان نظام شاه هجومه على برار واستولى على بعض أجزاء منها (rی) نتيجة للاك دخل عماد شاه في تحالف مع ميران محمد خان حاكم خاندش الذى سار

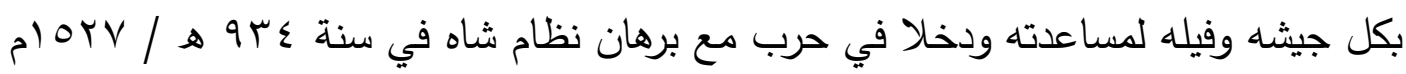
، فكان النصر في البداية حليف حاكم برار وخاندش ولكن عماد شاه ارتكب خطأ عسكري حيث فرح بهذا النصر وسمح لجنوده بالتثرق لجمع الغنائم ، فاستطاع بورهان نظام شاه تجميع قواته بهري مرة اخرى ومهاجمة قوات خانشش فقتل منهم الكثير واستولى على ثلاثمائة فيل ، وعلى إثر ذلك فر محمد خان إلى آسير وكذلك فر عماد شاه ، وراسل كل منهما السلطان الكجراتي لمد يد العون ، فأرسل محمد خان رساله يشرح فيها غدر بورهان نظام شاه بحرى وأنه بعد معاهدة السلام السابقة خان العهد وحاربه وانتصر عليه واخد منه ثلاثمائة فيل ، وأرسل عماد شاه ابنه للسلطان بهادر لمرافقته وطلب العون منه لاخول الدكن ، نوى السلطان تحقيق التماسه والتوجه إلى الدكن ، وبالفعل تحرك السلطان بهادر شاه إلى الدكن لوضع حد لتجاوز برهان نظام شاه

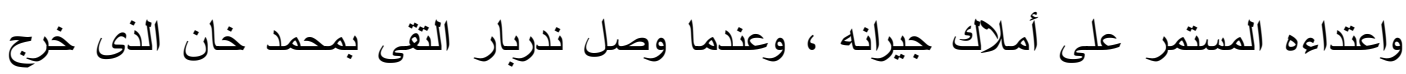
بيشه ليكون في عون سلطان الكجرات ، وبعد هذا اللقاء منحه السلطان بهادر لقب " شاه " فأصبح اسمه " محمد شاه " وانتقل بذلك من درجة خان إلى درجة " شاه "، ومن تلك اللحظة

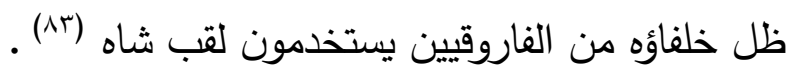
بعد تدخلات السلطان بهادر شاه وتحركه نحو أحمد نكر تمكن من بسط نفوذه ووجوده بها بالقوة ، وعندئذ انتهت الحرب بين الاطراف واعتراف عماد شاه بتبعيته للكجرات والدعاء لبهادر شاه على منابر دولته وسك العملة باسمه ، وكان ذلك بنصيحة من ميران محمد شاه لعماد شاه الذى كان آسفا لاستدعاءه لسلطان الكجرات ولكنه كان مضطرا ، ورجع كل منهما لولايته ، وكذلك انصاع نظام الملك بحرى وأعلن ولاءه للكجرات (ءء) .

كانت العلاقة قوية بين السلطان بهادر شاه وابن اخته " محمد شاه فاروقي " بسبب صلة القرابة وبسبب انعامات بهادر شاه عليه ، مما جعل " محمد شاه ملازما لخاله في فتوحاته في الدكن ومالوه وجيتور (^o) ، وكان السلطان بهادر كثير الاعتماد عليه في العديد من المهام

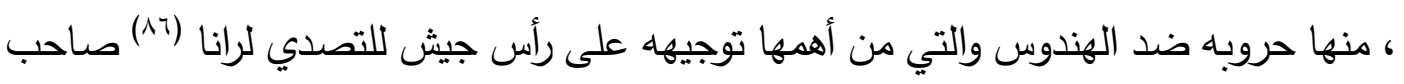


" جيتور " ، وعهد إليه أيضا فتح قلعة " كاكرون " في مالوه ، ثم تبعه السلطان نحو هذه القلعة

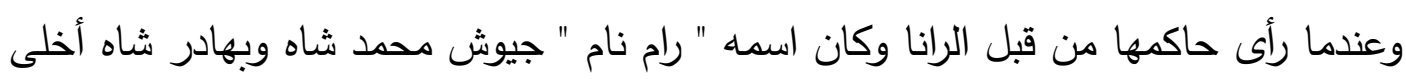

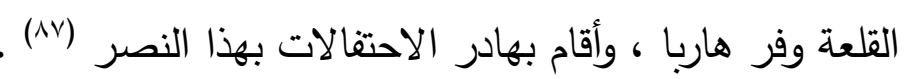
كما كان أيضا لمحمد شاه فاروقي دور مهم مع السلطان بهادر حين استخدمه في

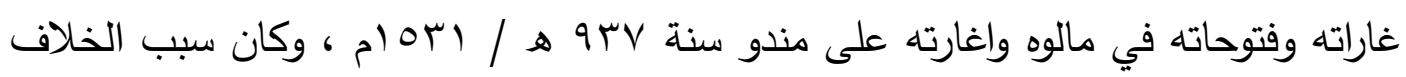

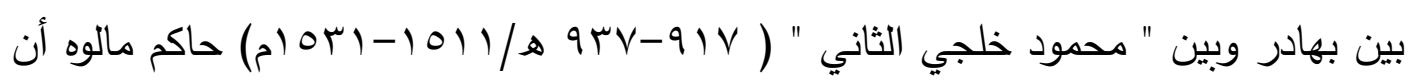

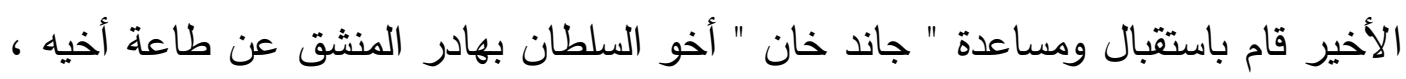
وحاول مساعدته للوصول للحكم على حساب بهادر وكان يتعامل مع الخارجين على دولة بهادر شاه ، وقابل بهادر تلك المعاملة بالمثل ، وظلت المكاتبات بين الاثثين وكان بهادر يطلب فيها

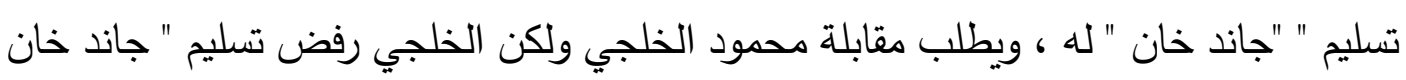
" وأخذ يماطل في اللقاء خوفا من بهادر ، حتى قرر بهادر الإغارة على مالوه ، فبدأ حصار التهار مندو حتى انتصر وارتفعت راياته على قلعة مندو وقام بأسر محمود الخلجي حاكم مالوه هو وأولاده (^^)

بعد كل هذه الانتصارات التي حققها السلطان الكجراتي بهادر شاه استطاع " همايون

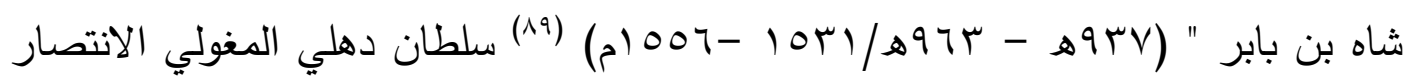

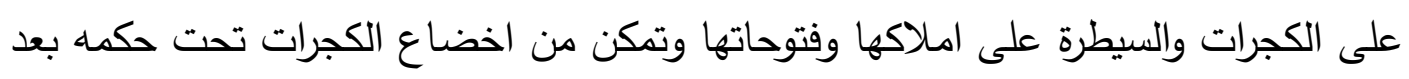

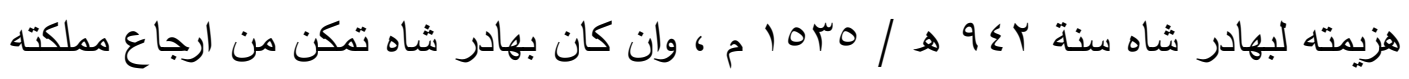

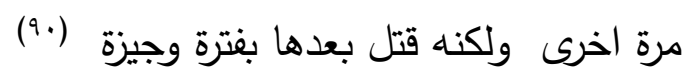
تولية ميران محمد شاه الفاروقي سلطانا على الكجرات

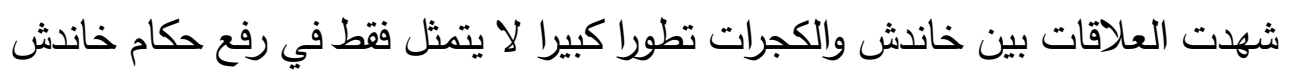
من الإمارة الى السلطنة بتلقيب محمد خان بلقب محمد شاه ، أو في الاعتماد عليه في الفتوحات لهات لهات والحروب التي خاضها بهادر شاه ، حين اعتمد على ابن اخته واعطاه الكثير من المهام في هذه الحروب لثتته فيه ، ولكن كان محمد شاه فاروقي هو المرشح الأمثل من قبل خاله لتولى الثى

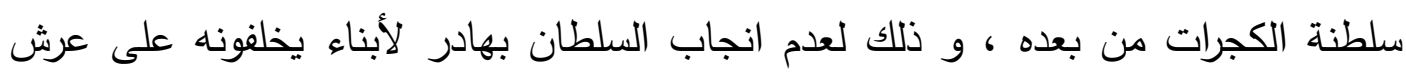
الكجرات ولقضائه على إخوته ليسيطر على الحكم بمفرده ، بالإضافة لمحبته لمحمد شاه فاروقي ، وهذه هى أكبر مكانة وصل إليها حكام خاندش وأكبر تطور للعلاقة بين الطرفين (19) 
، وكانت هذه اللحظة لحظة فارقة في تاريخ خاندش وفي علاقاتها مع الكجرات فهنا حدث تحول لخاندش من تابعة للكجرات إلى صاحبة الكلمة العليا فيها وسوف يظهر ذلك من خلا فلال الأحداث التالية .

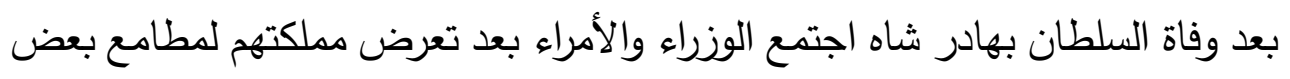

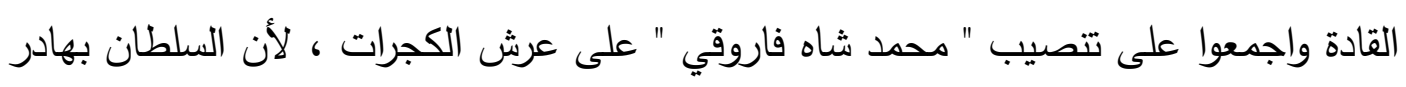

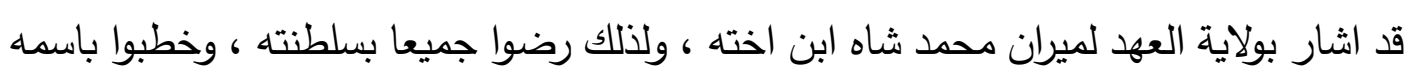

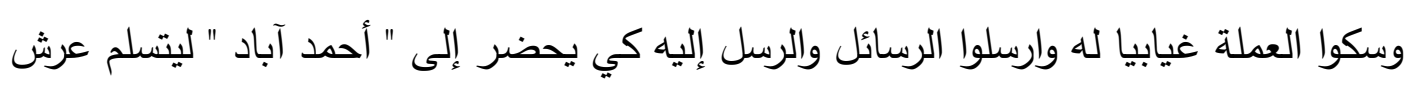
الكجرات طبقا لوصية بهادر شاه ، وعندما وصل الخبر لمحمد شاه فاروقي حزن لموت خاله وتوجه للكجرات ليتولى السلطنة ولكنه توفي قبل وصوله إلى الكجرات وقيل أنه مات موتة طبيعية بعد قراءة الخطبة باسمه شهرا ونصف الشهر ، ثم نُقِلَ جسده إلى بورهانبور ودفن في

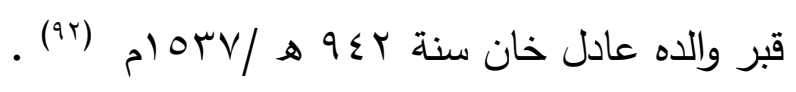
وكانت خطوة ترشح أحد حكام خاندش لتولى حكم الكجرات سابقة مهمة كان لها اثرها على الفاروقيين وعلى العلاقة التي جمعت بينهم وبين حكام الكجرات ، ففي الفترة التالية ستثهد العلاقات نوعا كبيرا من التغير بين الطرفين سيحاول فيه حكام خاندش ليس فقط التخلي عن

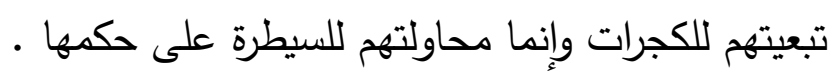
والجدير بالذكر أن أبناء محمد شاه كانوا صغاراً في السن لذلك تولى زمام الحكم أخوه " ميران مبارك شاه " ، ومن الملاحظ في هذه الفترة ازدياد نفوذ الفاروقيين فلم يكتفوا بترشيح محمد شاه لسلطنة الكجرات الذى توفى قبل الاستلام الرسمي لها، لكن نجد طموحهم أصبح كبيرا حيث فكر مبارك شاه في تولى السلطة في الكجرات ، ومما شجعه على ذلك أن بهادر شاه لم يترك وريثا للعرش من أسرة المظفر شاهيين لأنه قام بالتخلص من اخوته وأقاربه إلا "

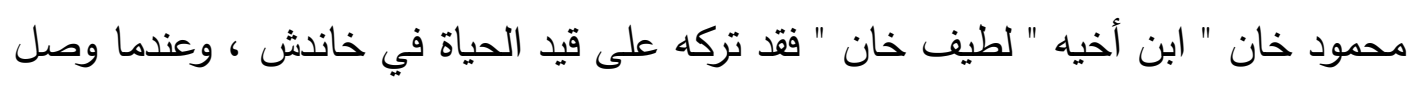

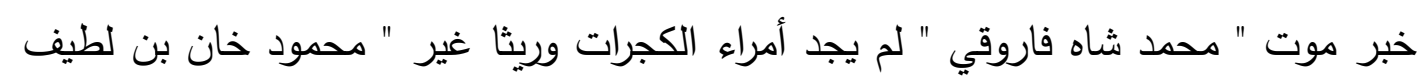
خان بن مظفر شاه " ، وهنا قرر أمراء الكجرات ارسال الرسل لاستدعاء " محمود خان " لاجلاسه على عرش الكجرات ، لكن مبارك شاه رفض تسليمه لهم وذلك لأنه كان يطمع في هذا العرش ، وهنا قرر أمراء الكجرات اخذه بالقوة واستعدوا لذلك وعندما علم مبارك شاه بهذا لأل

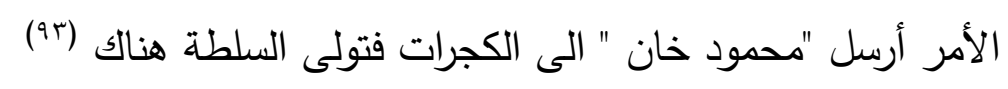




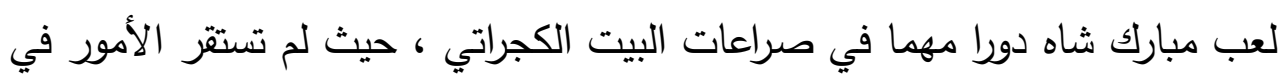

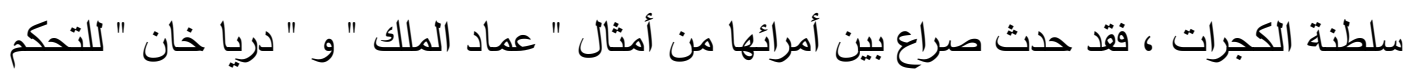

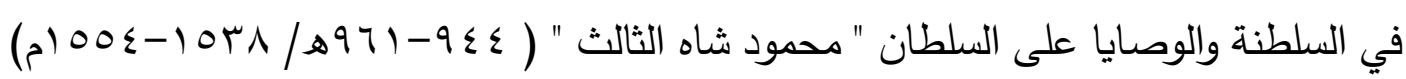

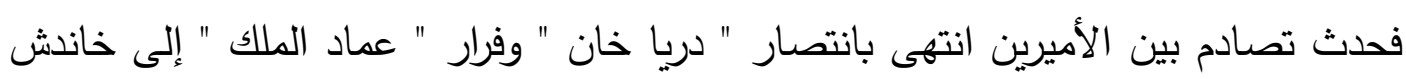

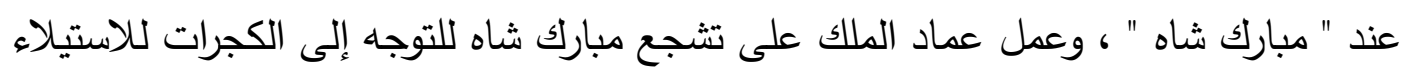

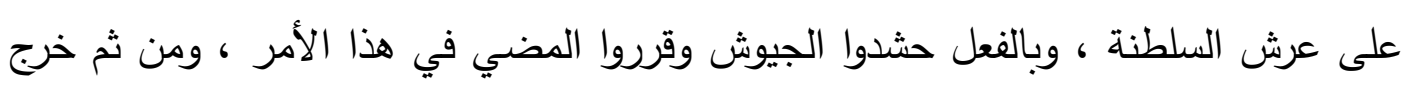

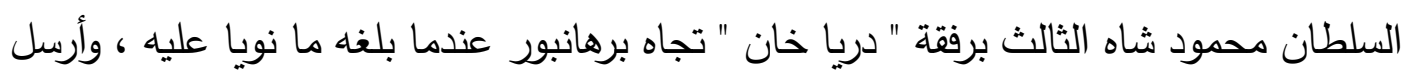

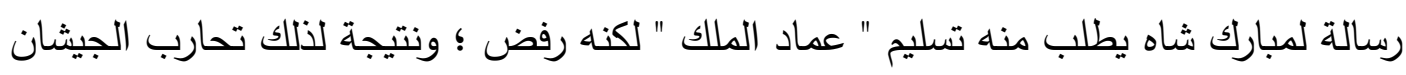

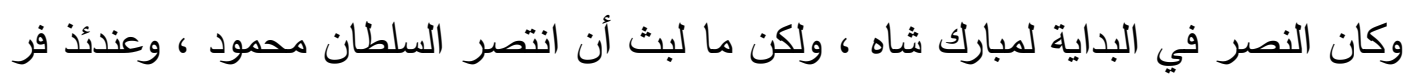

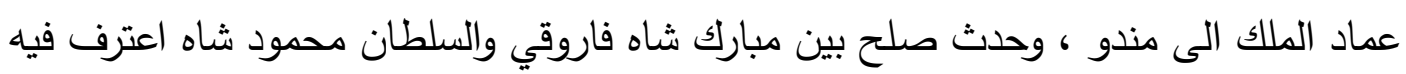

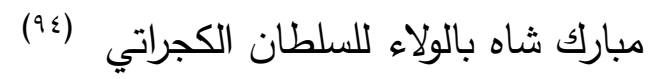

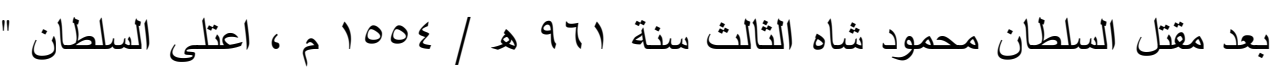

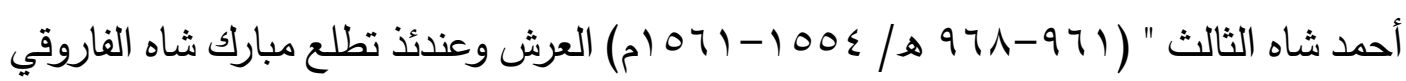

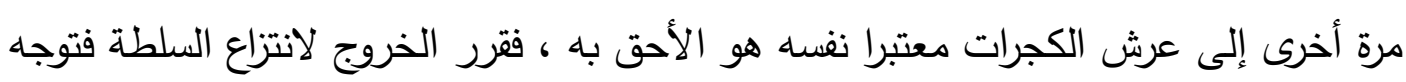

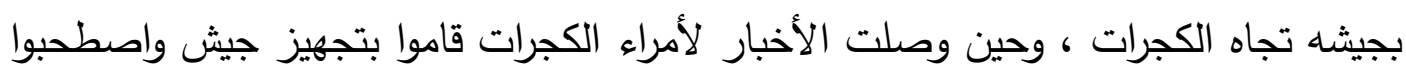

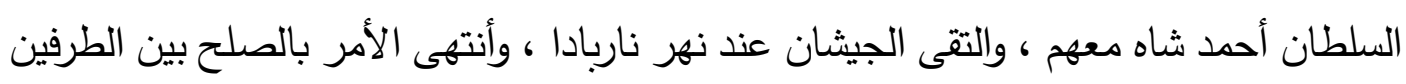
وعاد مبارك شاه إلى خاندش (90) .

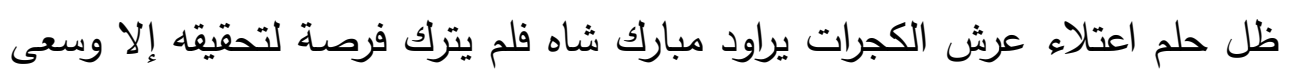

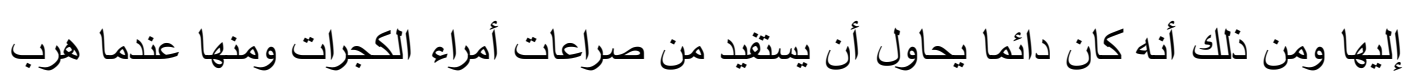

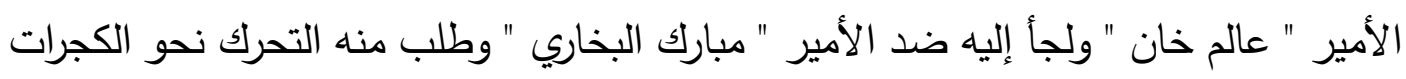

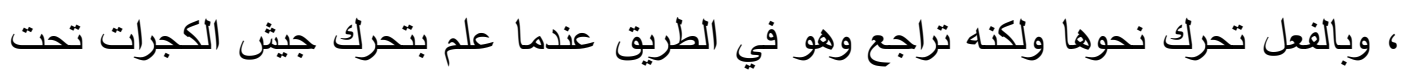

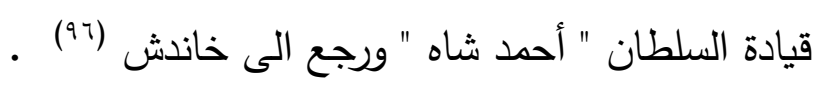
ومن تدخلاته أيضا تدخله في الصراع بين " اعتماد خان " و " عماد الملك " أمراء

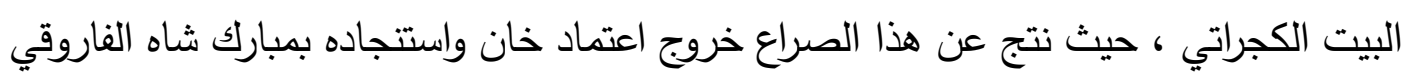

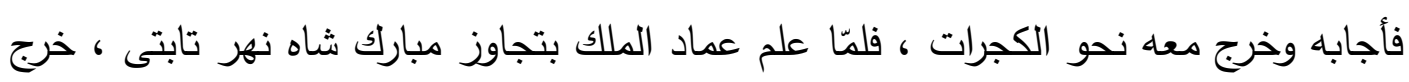

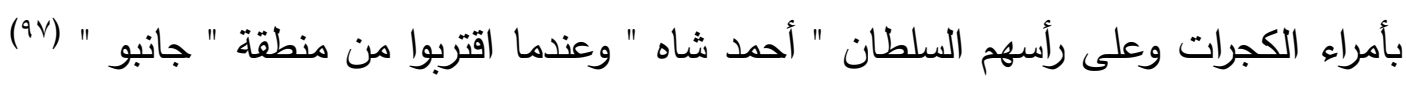


كان قد وصل إليها مبارك شاه بعشرين ألف فارس ، ولكن انتهى الأمر بينهم إلى الصلح ورجع

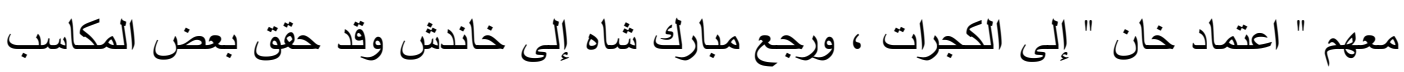

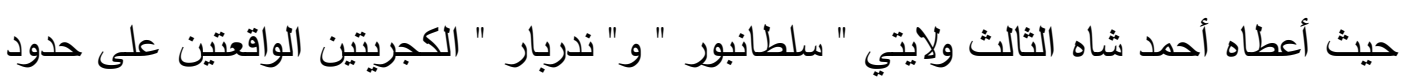

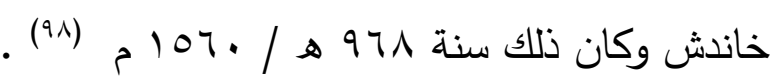
ويظهر من خلال هذه الأحداث مدى القوة التي وصلت إليها خاندش والأسرة الفاروقية في تلك الفترة الزمنية ، فبعدما كانوا تابعين لسلطنة الكجرات أصبحوا في تلك الفترة هم المسيطرون والمتحكمون في مجريات الأمور ، والكجرات هي من تلجأ إليهم ، هذا بالاضافة

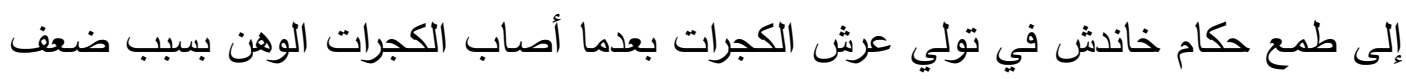

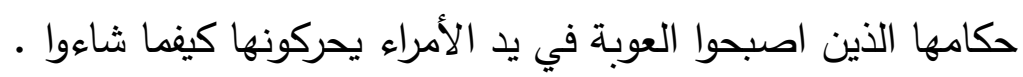

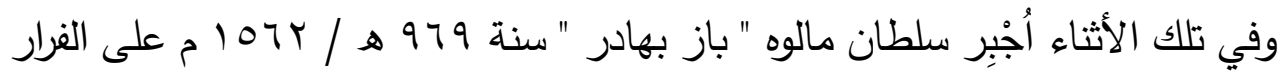
من بلاده أمام القوات المغولية ، فلجأ إلى مبارك شاه في خاندش ، فتعقبه القائد المغولي حتى بألى خاندش وتغلغل بجيشه حتى وصل بورهانبور ، وأظهر فيها الفساد والنهب ، وارتكب الفظائع ؛ فكتب مبارك شاه إلى حاكم برار" تفال خان " يطلب منه المساعدة العاجلة ، فسار حاكم برار بكل قواته إلى خاندش بحماسة بالغة ، وانضم إلى مبارك شاه وباز بهادر ، وقامت القوات

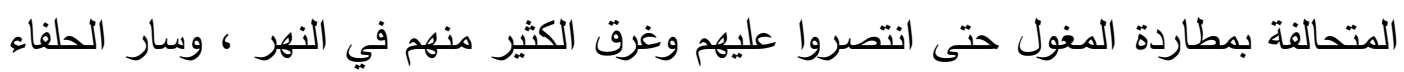

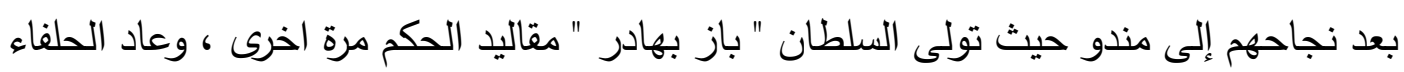

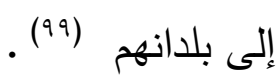
توفي السلطان " مبارك شاه " سنة 9 هـ / / 1077 م فخلفه في سلطنة خاندش ابنه " ميران محمد شاه الثاني" ، وفي تلك الفترة ظهر على مسرح الأحداث شخصية مهمة من أمراء البيت الكجراتي وهي شخصية " جنكيز خان ابن عماد الملك "، الذى بدأ يُظْْهِ التمرد وعدم الطاعة لأنه يشك في نسب السلطان " مظفر شاه الثالث" الذى تم وضعه من قبل "اعتماد خان " على عرش الكجرات مدعيا نسبه للسلطان " محمود شاه الثالث " وهنا حاول جنكيز خان أن يستيد من الموقف وقرر التوجه من الولاية التي يحكمها ليستولي على قصبة " بروده "(...)

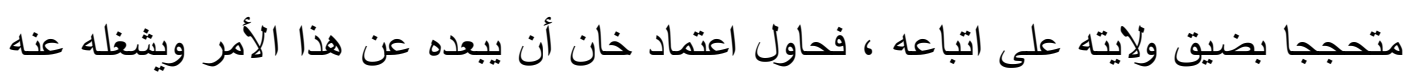

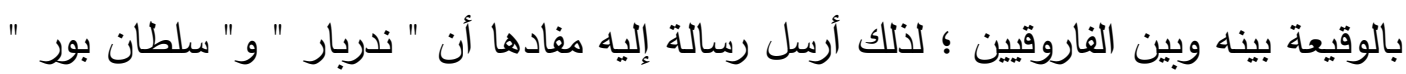
كانتا من أملاك الكجرات وأخذها مبارك شاه من السلطان " أحمد شاه الثالث " وطالما مات 
الاثنان فلابد من استعادة تلك البلاد ، وبالفعل اقتنع جنكيز خان بهذا الكلام وخرج من ولايته

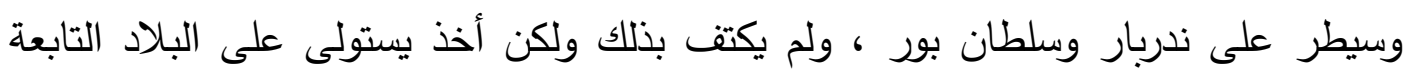
لخاندش حتى وصل الى " تهالنير " ونزل على نهر تباتى ، فخرج محمد شاه الثاني الفاروقي

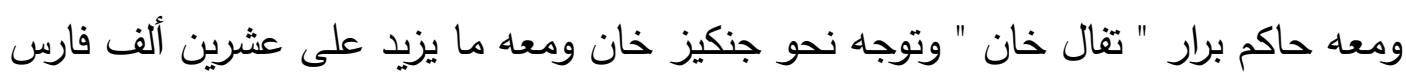

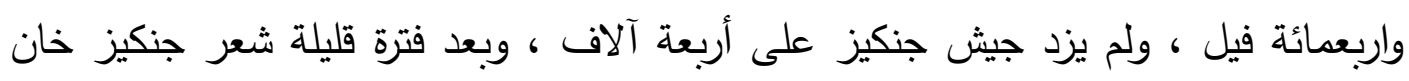

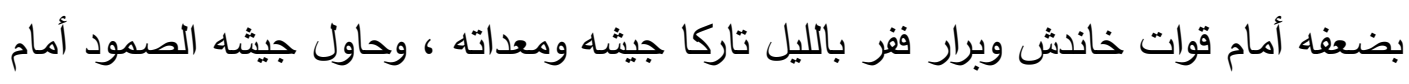

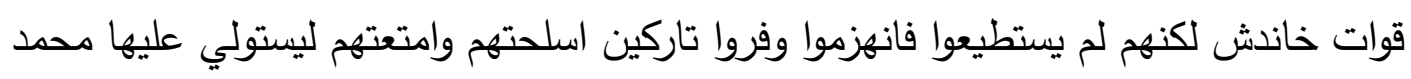

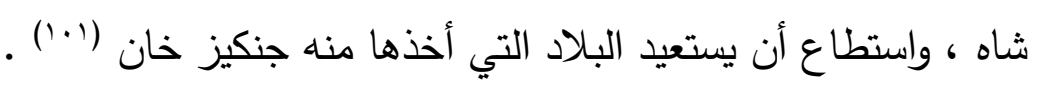
في هذه الفترة حدث ارتباك كبير داخل سلطنة الكجرات بسبب الخلاف على شخصية السلطان " مظفر شاه الثالث " ، حيث ادرك جنكيز خان خديعة اعتماد خان حين اوقع بينه وبين الفاروقيين وأن ذلك كان للخلاص منه فقرر الانتقام ، فقام بالتحرك بجيشه مدعوما بقوات

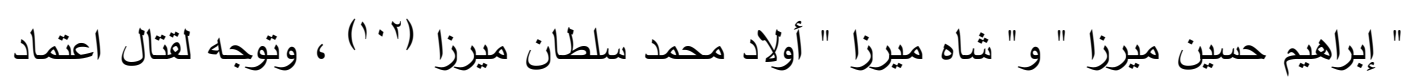
خان واستطاع النصر عليه ، ففر اعتماد خان والسلطان مظفر شاه الثالث ؛ فاستولى جنكيز

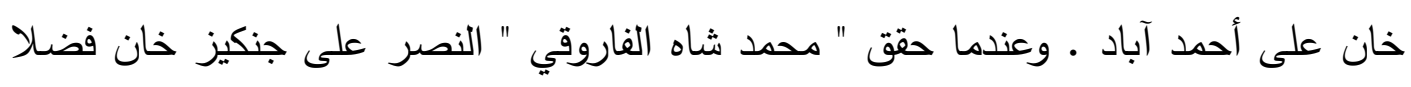
عن اضطراب احوال الكجرات والتشكك حول شخصية " مظفر شاه الثالث " قرر محمد شاه الفاروقي أن يكمل المسيرة ويطالب بأحقيته بعرش الكجرات وأنه هو الأحق به ، وخرج بجيشه المكون من ثلاثين الف فارس وتوجه الى أحمد آباد ، وهنالك خرج جنكيز خان بقواته والتحم الجيثان وتمكن جنكيز من النصر على محمد شاه الفاروقي ، مما جعله يفر منهزما إلى آسير

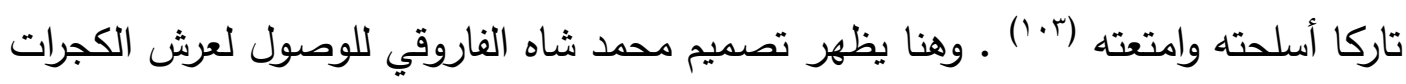
كما يظهر مدى قوة الفاروقيين في تلك الفترة ، لدرجة وصولهم إلى أحمد آباد معقل الكجرات ، وذلك نتيجة الضعف والتفكك الذى أصاب الكجرات بسبب الصراعات الداخلية .

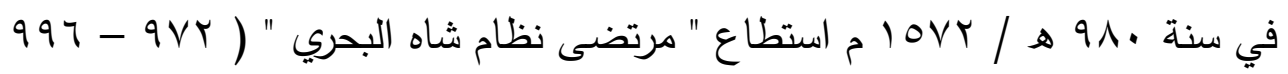

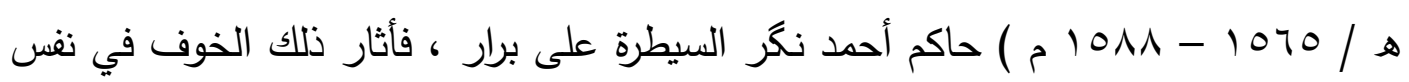

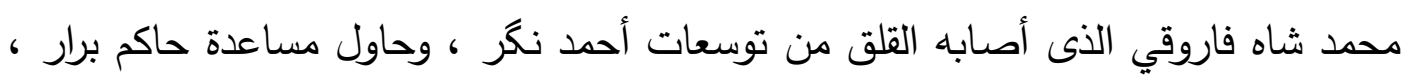

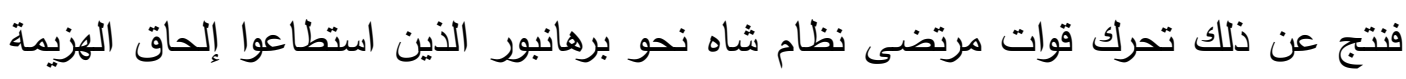
بمحمد شاه فاروقي مما اضطره إلى الفرار إلى آسير للتحصن بها نـاه ، فتبعه جيش أحمد نكر 
وانتهى الأمر بمعاهدة سلام دفع فيها محمد شاه فاروقي مبلغ كبير من المال لحاكم أحمد

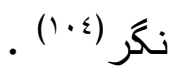

\section{علاقة الفاروقيين بحكام دهلي المغول وسقوط إمارة خاندش}

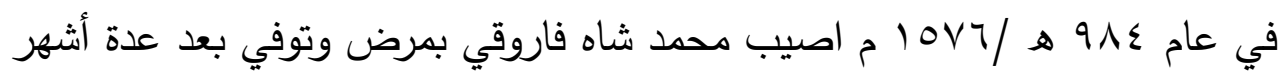

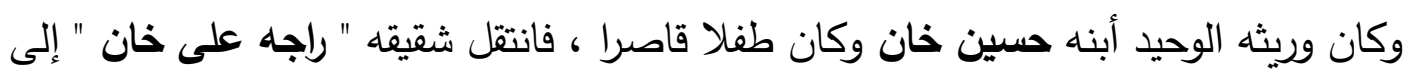
بورهانبور وقام الأمراء باستقباله ووضعاه على عرش خاندش ، وفي تلك الفترة كان السلطان

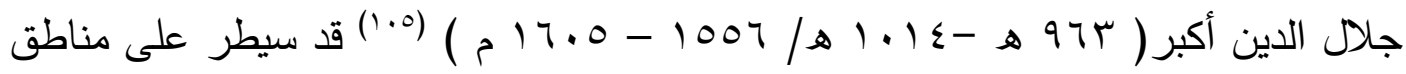
كبيرة من البنغال إلى السند واخضع كثير من الممالك منها مالوه والكجرات وغيرها ، فما كان من راجه على الفاروقي إلا ان يُسنقِطِ عن نفسه لقب شاه ، حتى لايثير السلطان جلال الدين

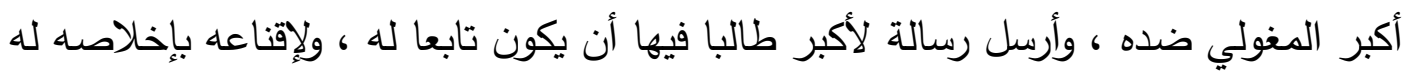

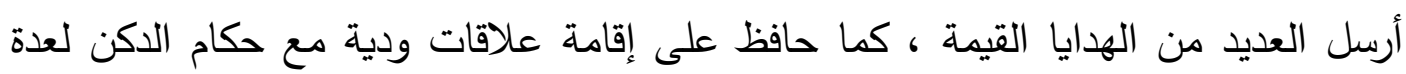
سنوات فقد كان راجه على خان يتميز بالحكمة والقدرة على سياسة الأمور (†.') .

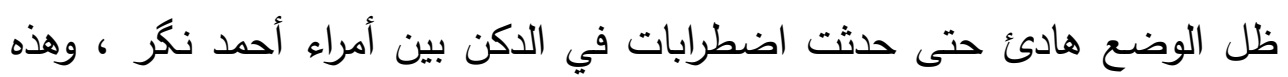

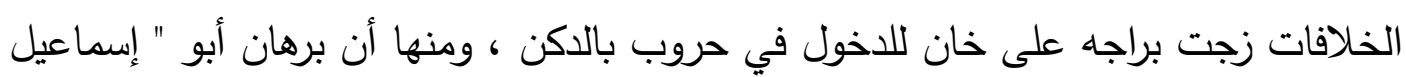

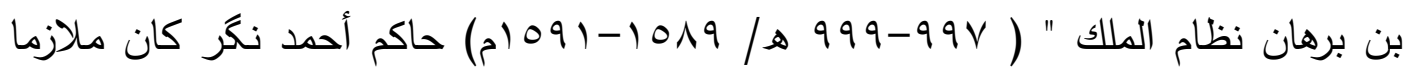
للسلطان أكبر عندما فر من سجن بلاده ، فحينما سمع باضطراب الدكن توجه إليها بتحريض هُ نهر

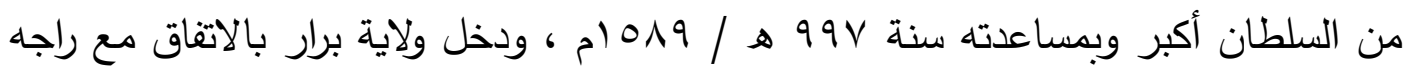
على خان حاكم خانش الذى جاءه أمر من السلطان أكبر لمساعدة برهان في حربه وتمكينه من عرش أحمد نكر ، وبالفعل استطاع أن يستولى على ولاية برار ، فقام جمال خان أحد أمراء

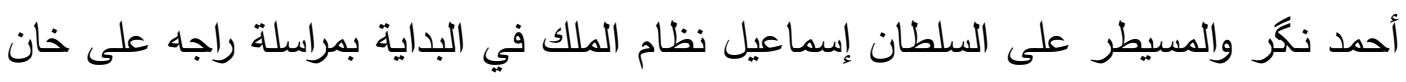
عارضا عليه بعض المكاسب على ان يتخلى عن مساندة المغول ومساندة برهان نظام الملك ، لكن على خان رفض ؛ مما أضطر جمال خان إلى التوجه نحو راجه على خان الفاروقي لمقاتلته عندما علم بقدومه بصحبة برهان الملك ، لكن راجه على استطاع أن يراسل اتباع جمال خان واستمالتهم إليه ، مما جعلهم ينفضون من حول جمال خان الذى لم يبق معه إلا القليل

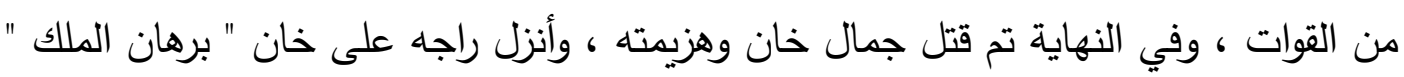

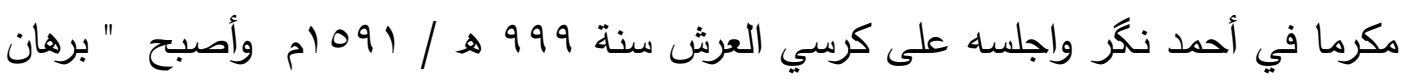




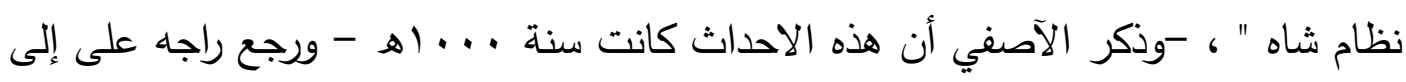

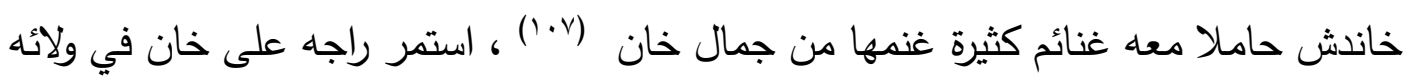

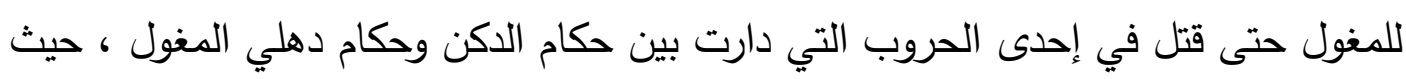

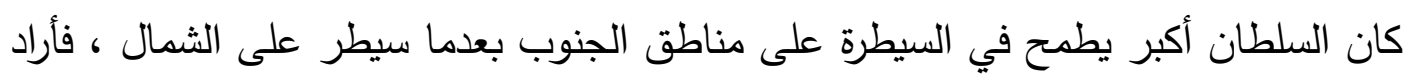

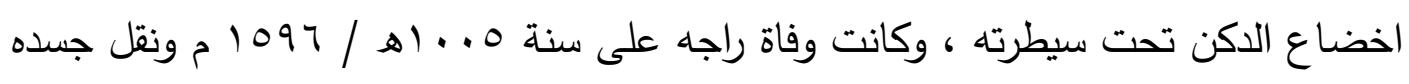

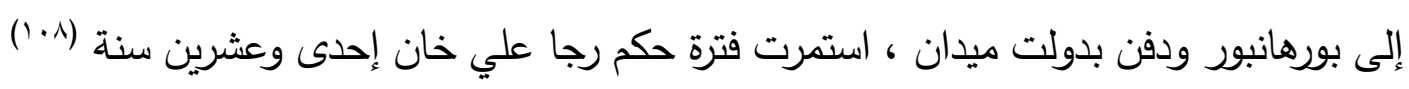

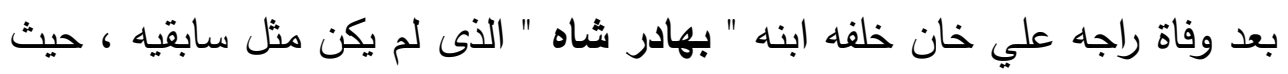

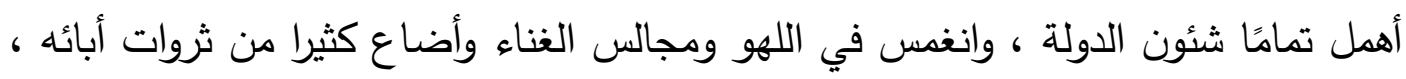

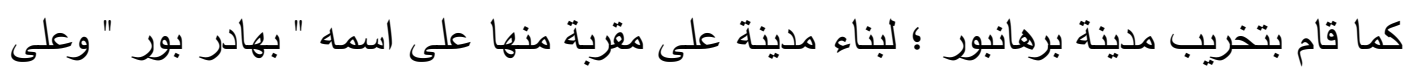

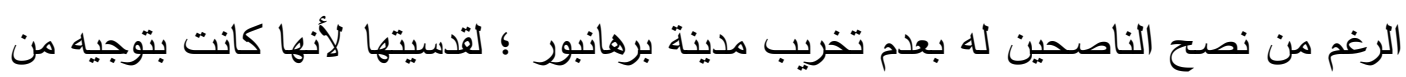

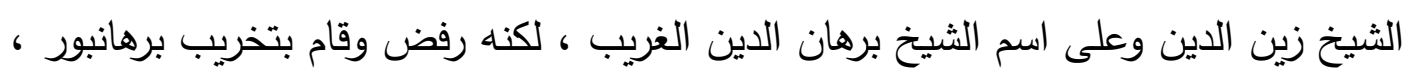

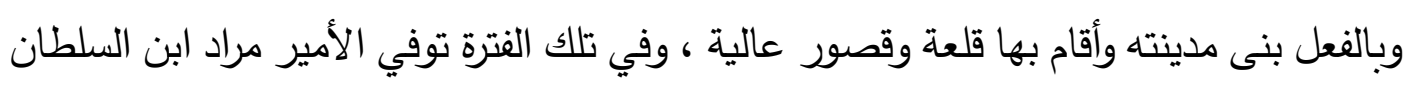

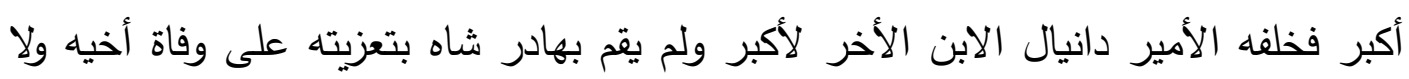
تهنئة على توليه قيادة القوات في الاكن كما جرت العادة (9. (1) .

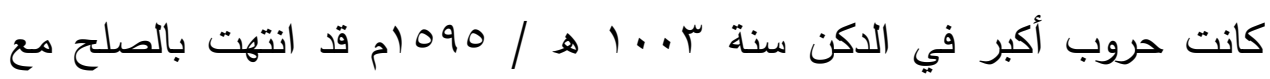

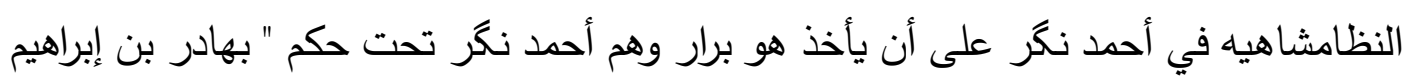

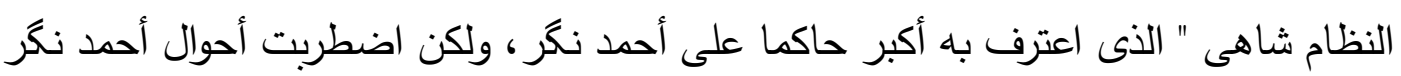

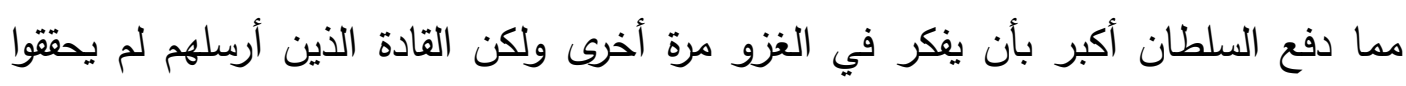

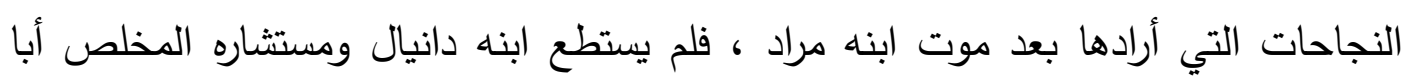

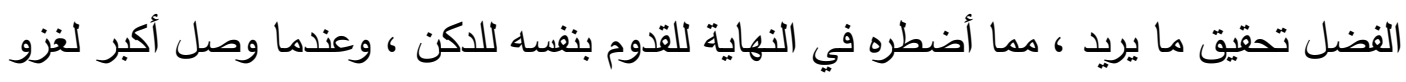

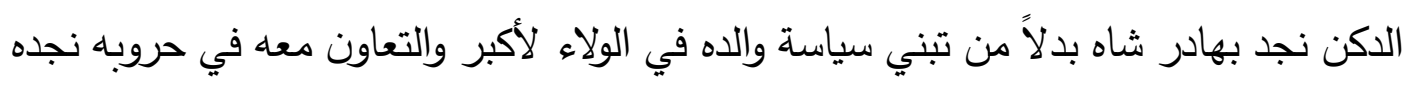

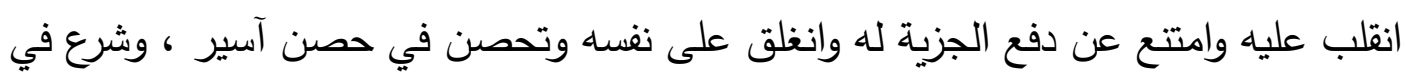

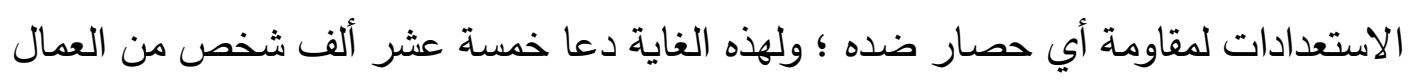

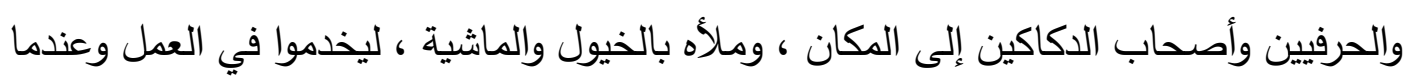

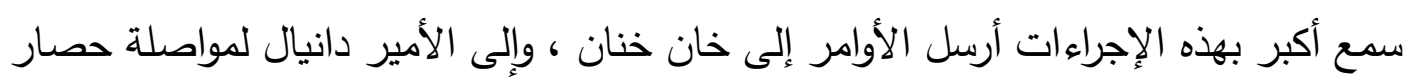

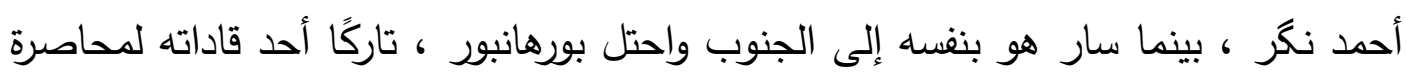


آسير ، استمر حصار هذه القلعة لفترة طويلة تصل لمدة سبعة أشهر ، دافع عنها المحاصرون بثدة ، مما دفع أكبر إلى استقطاب بعض الأمراء بالمال لإضعاف المقاومة ، كما تفشت

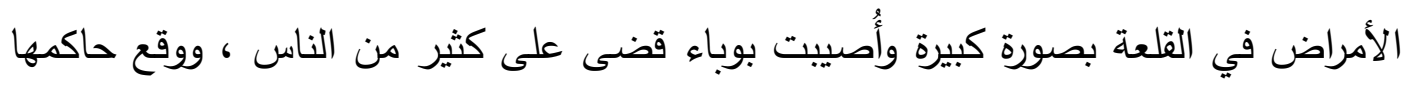

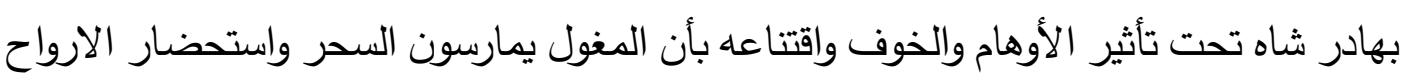
وفي نهاية الأمر استسلم بهادر شاه وسقط الحصن ؛ وبسقوطه سقطت خاندش في يد أكبر

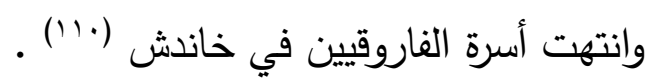
وهناك اختلاف في سنة انتهاء ملك تلك الأسرة بخاندش حيث ذكر الآصفي ('l') في

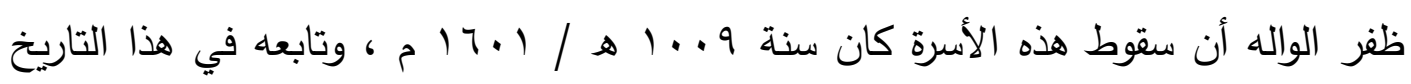

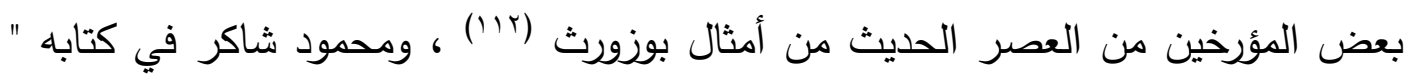

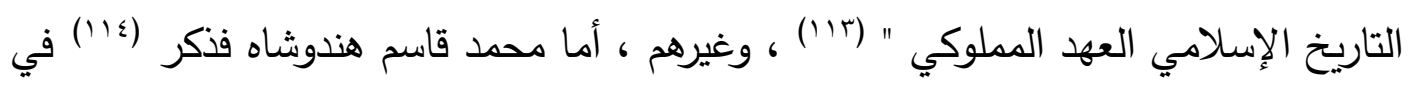

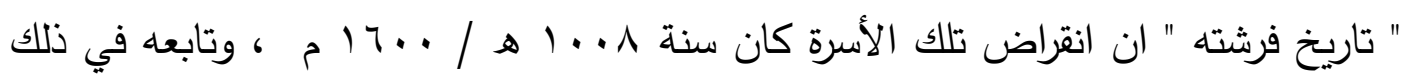

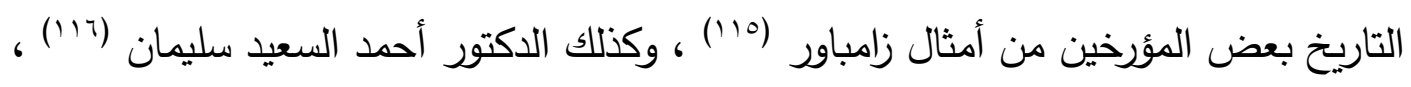

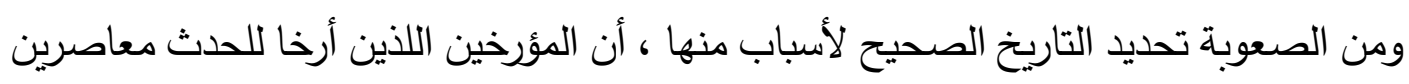

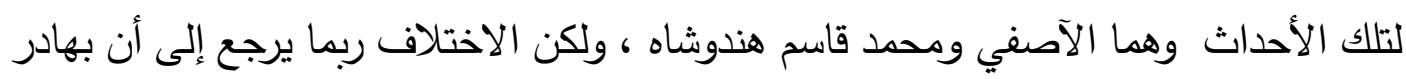
شاه استسلم بعد حصاره في حصن آسير ، ولكن ظل الحصن صامدا بعد تتازله تحت قيادة ملك ياقوت سلطاني لمدة شهر آخر وكان به كثير من الأمراء الفاروقيين، حتى سقط في النهاية

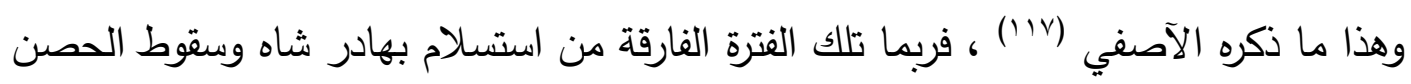
هى التي أحدثت الاختلاف ، وأميل لترجيح رأي الآصفي بأن سقوط الأسرة الفاروقية كان سنة 9 . . 1 هـ / 1 ـ 17 م واستتد في ذلك على أن الآصفي ذكر بنفسه في كتابه " ظفر الواله "

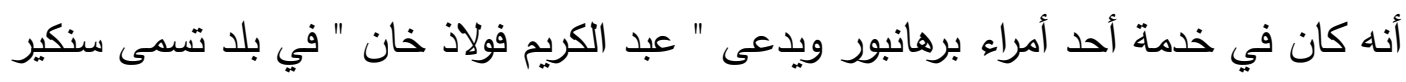

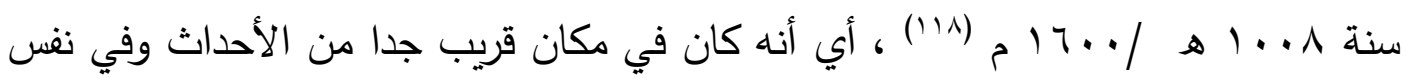

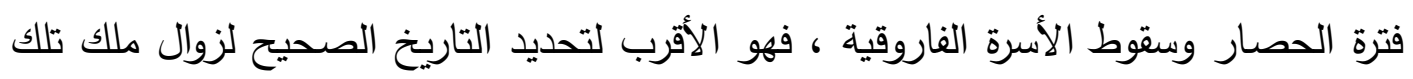
الأسرة .

وقد حكم الفاروقيون خانش لفترة امتدت لمائتين وخمس وعشرين سنة هجرية (19) . 


\section{المحور الثالث : بعض الجوانب الحضارية للفاروقيين في خاندش}

أولا : الجواتب الاقتصادية :

لقد وفرت الطبيعة لخاندش مساحة واسعة من التربة الغرينية الخصبة والغنية وكانت تُروى هذه الأرض من خلال نهرين رئيسيين هما نهر ناربادا ، ونهر تابتي وروافدهما العديدة ، وهي مناسبة للغاية للزراعة وبالقليل من الجهد البشرى يمكن إنتاج الكثير من المنتجات الزراعية ، وكانت خاندش إمارة غنية وتحتوي على العديد من القرى والمدن المزدهرة التي تعج

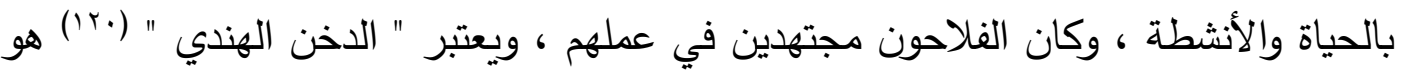
المحصول الرئيسي ، كما كان الأرز المنتج هنالك جودته عالية ، ونمت الأزهار والفاكهة ولمهية

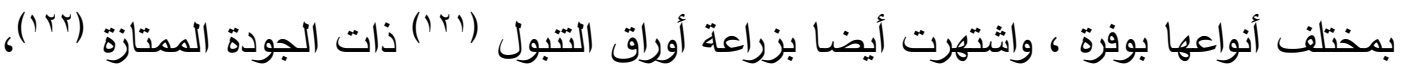

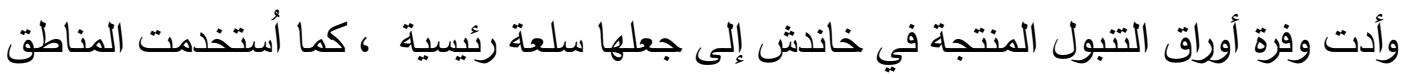
ذات التربة السوداء بخاندش في إنتاج القطن عالي الجودة ، والذي كان محصولا زراعيا مهما، وبفضله تم تطوير صناعة النسيج ، حيث اشتهرت المنطقة بشكل خاص بإنتاج الأقشة الفاخرة

تحتوي خانش على بعض الغابات الأكثر كثافة في الهند التي كانت تتتج أخشابًا وفيرة تم استخدامها كوقود ولأغراض البناء على حد سواء ، وقد أنتجت مناطق الغابات الكثيفة لمملكة

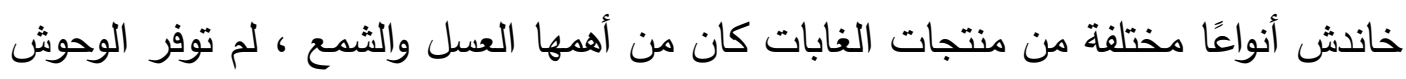

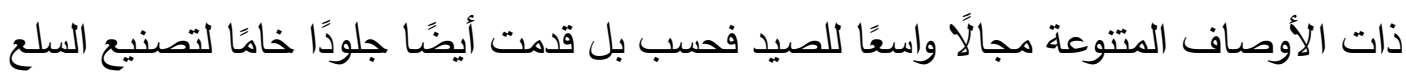
الجلدية والملابس ، وأدى توفر هذه الجلود إلى ازدهار صناعة الدباغة هناك ، وتم استخدام

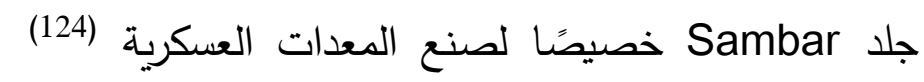
ولطالما كانت خاندش مع هطول الأمطار والسهول الواسعة المغطاة بالأعشاب وإمدادات المياه الوفيرة مركزًا مهمًا لتربية الحيوانات والماشية بأعداد كبيرة ، ومن أهمها الجواميس الأنسان

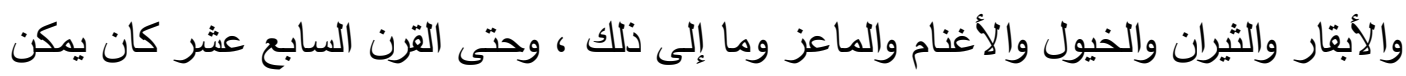

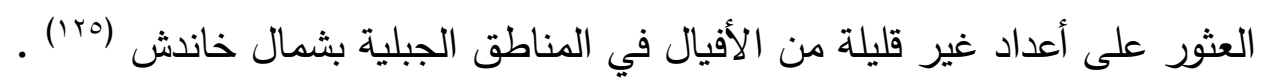

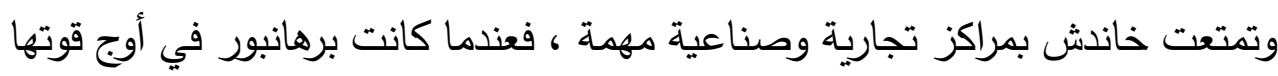
وكانت سورت (Trا) هي الميناء الرئيسي في غرب الهند ، كان الجزء الأكبر من حركة المرور 
الكبيرة بين البلدان الداخلية والساحل يمر عبر خاندش ، فكان الطريق التجاري الرئيسي يمر

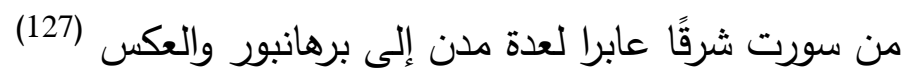
ثانيا : الجوانب العلمية والثقافية للفاروقيين في خانداش شهدت الحركة العلمية في خاندش قدرا كبيرا من النهوض في ظل حكم الفاروقيين وذلك بفضل اهتمامهم بالعلم والعلماء سواءً بتقديرهم للعلماء وتقريبهم إليهم أو بإنشاء المؤسسات

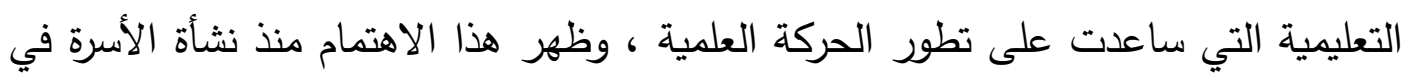

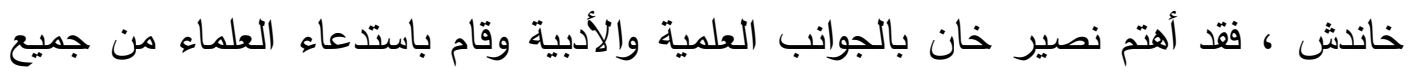

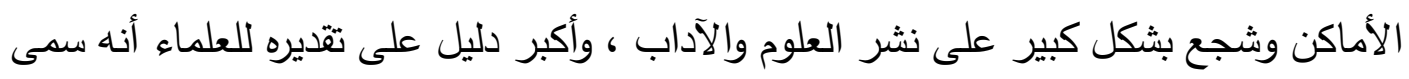

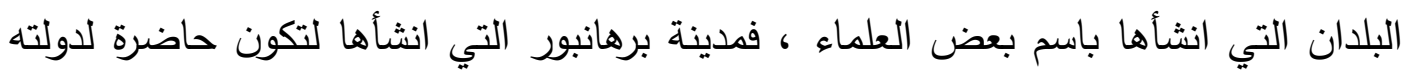
سماها بذلك الاسم نسبة للشيخ برهان الدين الغريب ، وكذلك مدينة زين آباد نسبة الى الشيخ

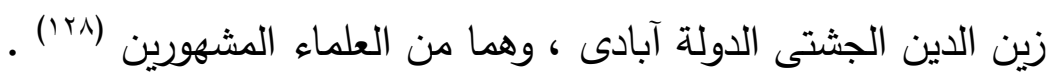

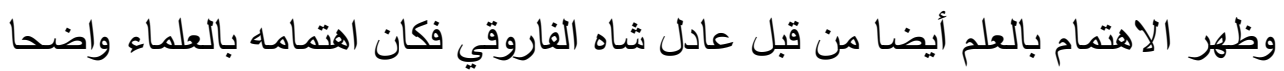
ومنه أنه احسن ضيافة الثيخ "علم الله الأميتهوي " وهو أحد العلماء البارزين في الفقه والحديث والعربية ، فعندما قدم إلى برهانبور أكرمه غاية الإكرام ، فشجعه ذلك ليقيم في برهانبور لمدة التهاء طويلة (199) ـ كذلك اهتم ميران محمد شاه الثاني بن مبارك الفاروقي بالعلم وأحسن استقبال وتكريم العلماء القادمين إلى خاندش من أمثال الثيخ " إبراهيم الثطاري البروجي الكجراتي "

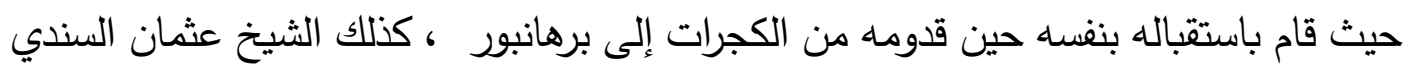

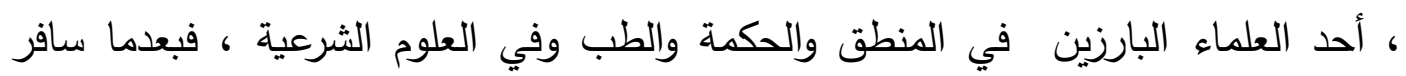

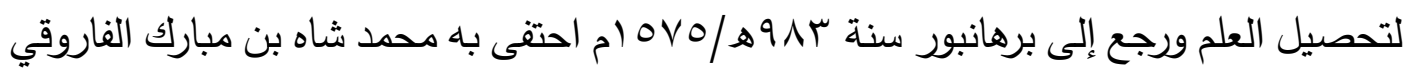

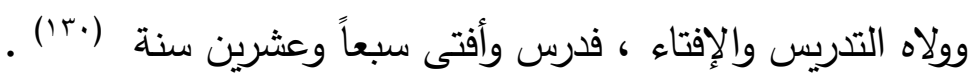

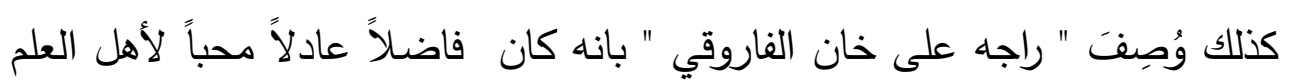
محسناً إليهم ، فمما ذكر عن اهتمامه بالعلماء أنه التقى بنفسه مع الثيخ " أحمد بن محمد

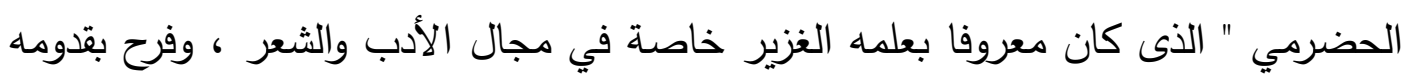

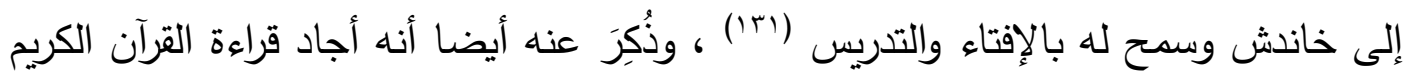
وهو سلطان وفي سن الكهولة (rrا) ، وغيرها من المواقف التي تدل على اهتمام الحكام الفاروقيين بالعلم والعلماء بإقليم خاندش سلط سئ 


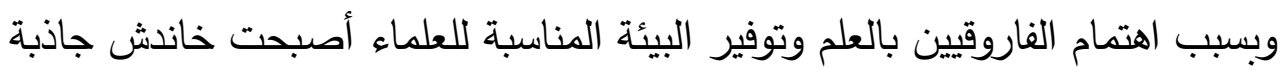

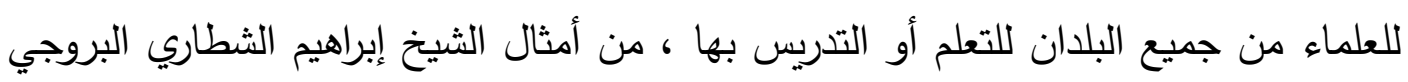

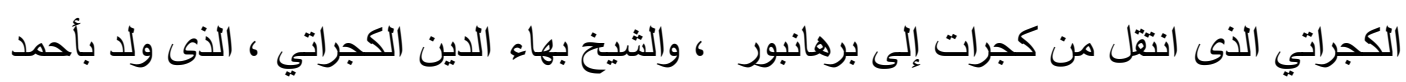

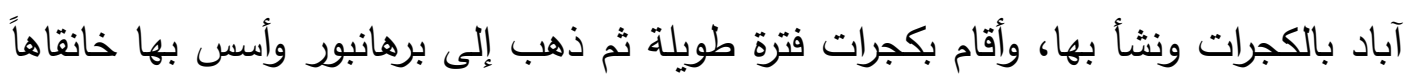

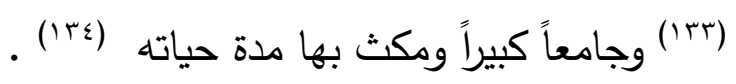

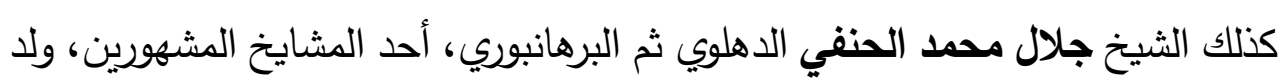

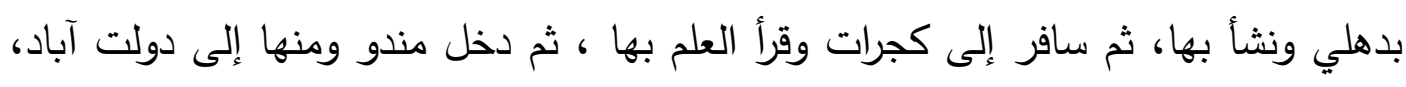

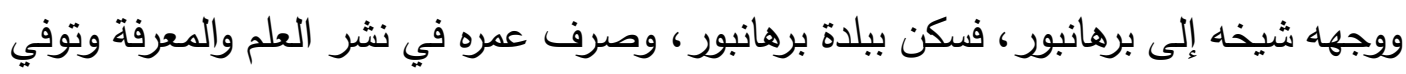

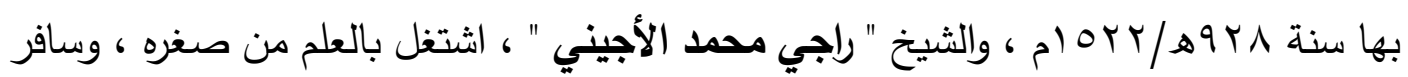

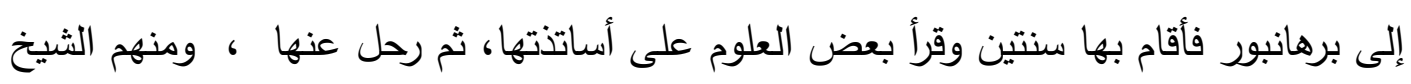

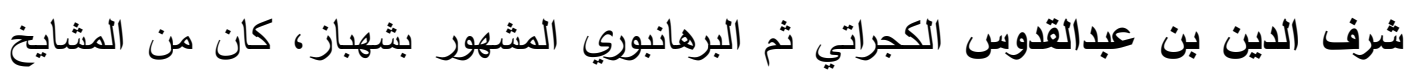

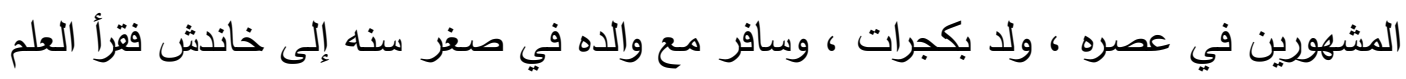

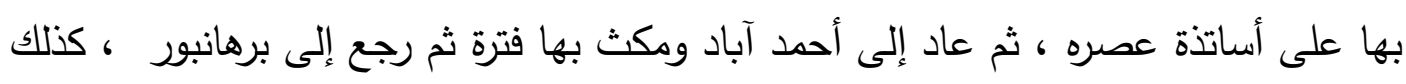

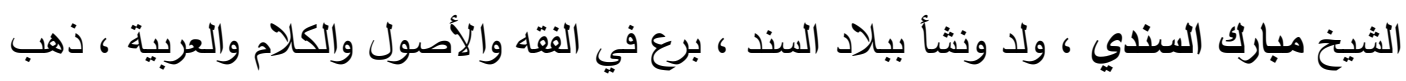

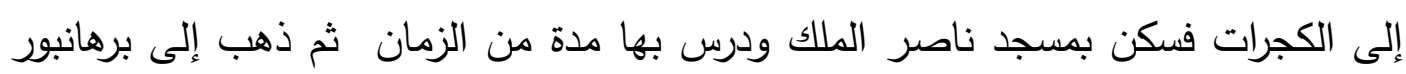

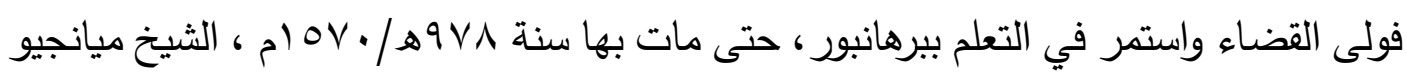

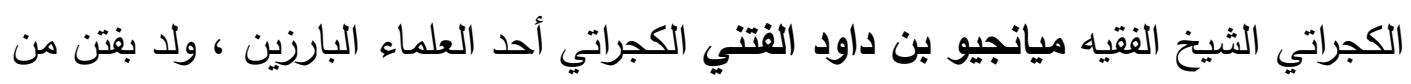

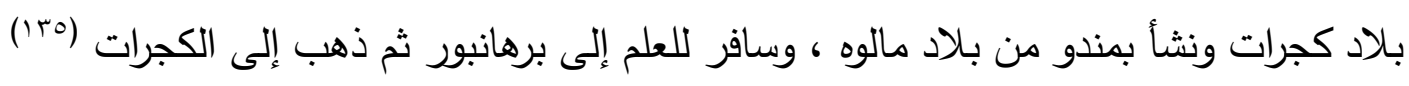

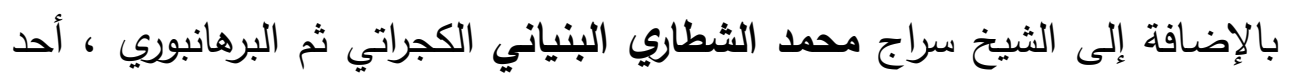

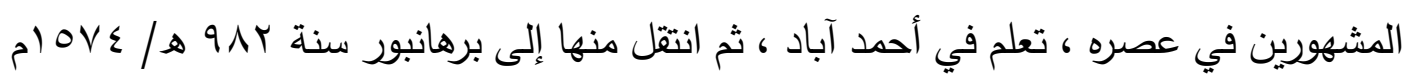

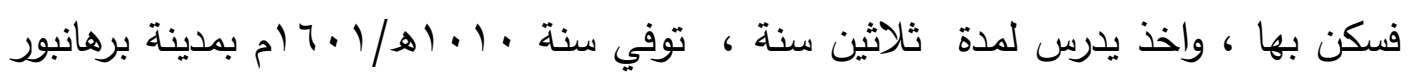

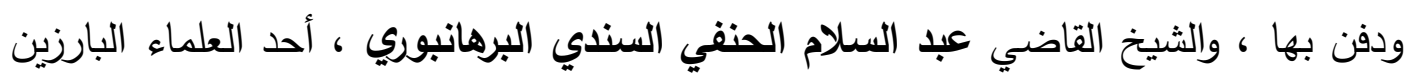

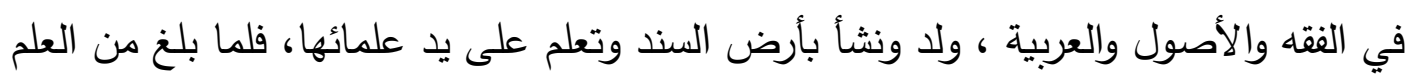

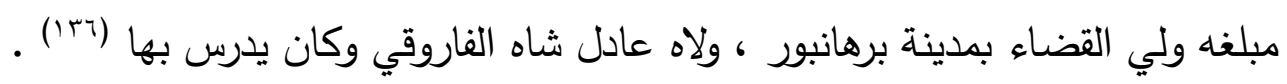

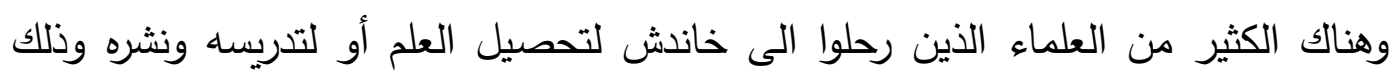
لككانتها العلمية الكبيرة . 


\section{المؤسسات التعليمية بخاندش في ظل حكم الفاروقيين}

ظهر اهتمام الفاروقيين بالجوانب العلمية والثقافية من خلال اهتمامهم بالمؤسسات التعليمية المتنوعة التي أسهمت بصورة كبيرة في نشر العلم بأرض خاندش وظهور مجموعة كبيرة من العلماء في مختلف المجالات العلمية ؛ حتى أصبحت خاندش كما ذكرنا جاذبة لكثير من العلماء من خارجها ، ومن هذه المؤسسات التعليمية :

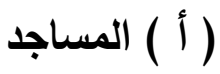

لم يقتصر دور المساجد في تاريخ الحضارة الإسلامية على العبادة وحدها، ولكن كانت

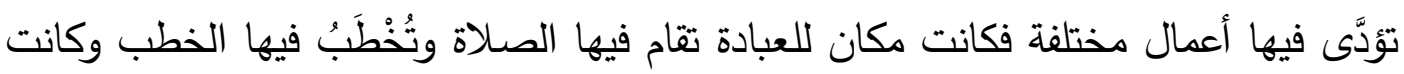
محكمة للتقاضي ، ومعاهد للتعلم ، وملجأ للغربب وغيرها من الامور المهمة ، والذي يهمنا

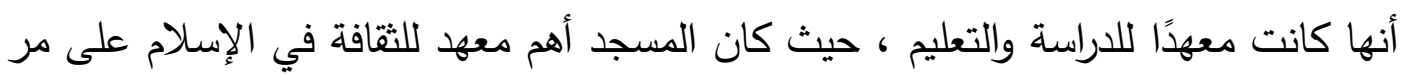
العصور (IrV) ، وعلى ذلك لعبت المساجد دورا مهما في العملية التعليمية كمؤسسة تعليمية

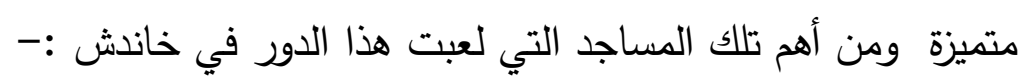
مسجد الثيخ إبراهيم الثطاري ، الذى كان مخصصا للتدريس والتعلم واستمر على هـ هـ ذلك فترة طويلة ، وممن قام بالتدريس فيه جمال الدين البرهانبوري أحد العلماء المشهورين (^זّا'). كذلك مسجد بيبي كي (مسجد السيدة) الذى تم بناؤه من قِبَل إحدى ملكات البيت الفاروقي ، ولكن اسمها مجهول ، وذلك لأنه لا يوجد نقش على المبنى ، وكذلك تاريخ إنشأؤه

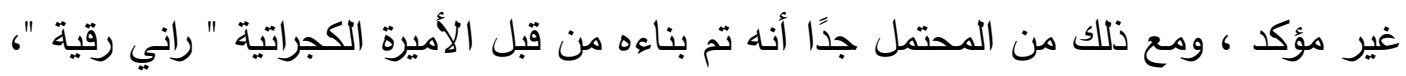
ابنة السلطان مظفر شاه الثاني وزوجة عادل شاه الثالث ، ومن المتوقع أن البناء تم ما بين

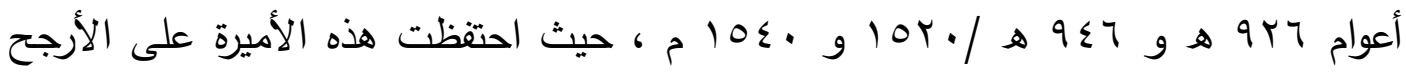

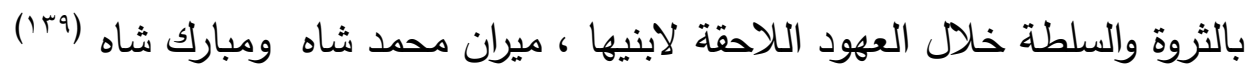

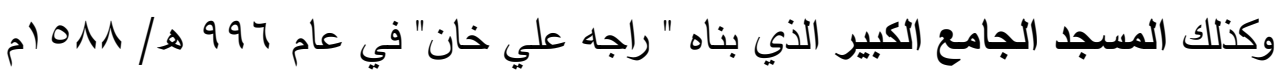
وكان يعد المسجد الجامع في برهانبور أحد المساجد البارزة في وسط الهند ، وممن درس فيه

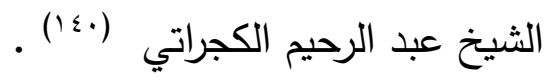




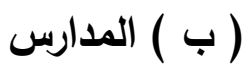

ومن المؤسسات التعليمية المهمة المدارس ، ومن أهم المدارس التي أنثأت في خاندش في عهد الفاروقيين : عهن المدرسة الكبيرة بعادل بور في خاندش بناها عادل شاه الفاروقي وهى من المدارس جميلة البناء وولى عليها الثيخ موسي السندي على التدريس وهو أحد فحول العلماء في النحو واللغة ، وكذلك مدرسة الثيخ ظاهر بن يوسف السندي بمدينة برهانبور ، درس فيها الثيخ ظاهر

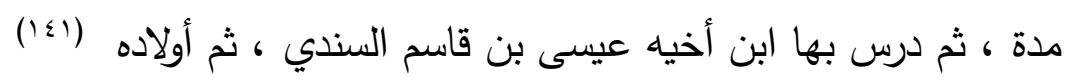
بعض علماء خاندش بسبب الاهتمام البالغ من قبل الفاروقيين بالعلم والثقافة أفرزت خاندش عدد كبير من العلماء المشهورين في كثير من العلوم يمكن ذكر بعضهم على النحو التالي : الشيخ أبو محمد بن الخضر بن بهاء الدين التميمي البرهانبوري، أحد المشايخ

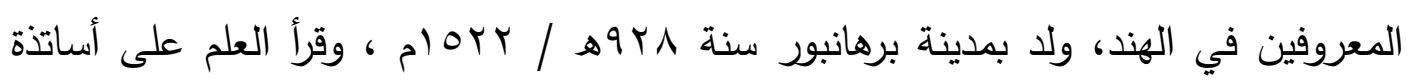
عصره، ثم سافر لعدة بلدان لتحصيل العلم حتى اصبح عالما كبيرا يأخذ عنه العلم ، توفي سنة

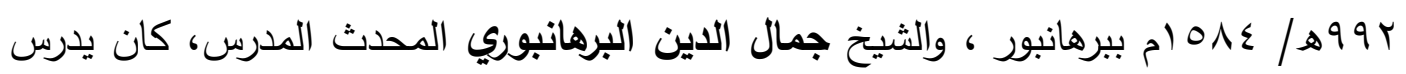
بمسجد الثيخ إبراهيم البهكري بمدينة برهانبور ، كذلك الثيخ بير محمد بن عبد الحليم بن جلال

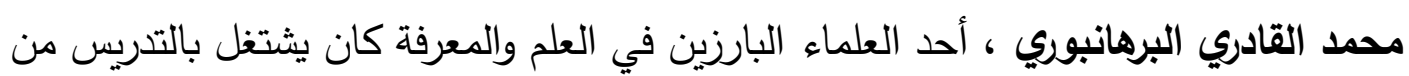
الصباح إلى المساء ، لا يتعطل عن ذلك في يوم من أيام الأسبوع ، ولذلك لم يرغب قط في

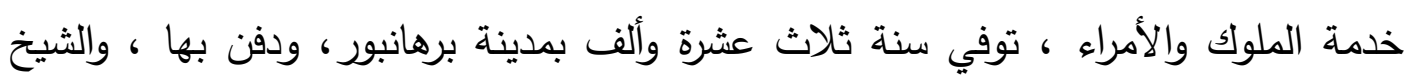

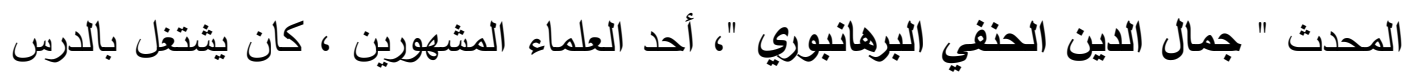

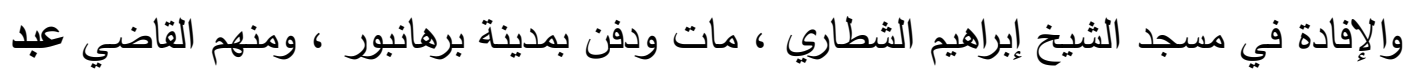
الغني الخانديسي : الثيخ الفقيه قاضي القضاة عبد الغني الخانديسي، أحد العلماء البارزين

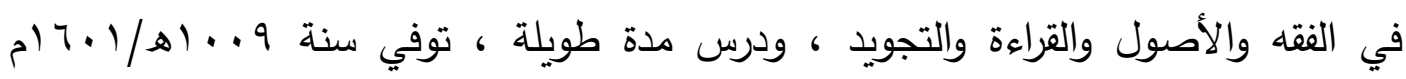

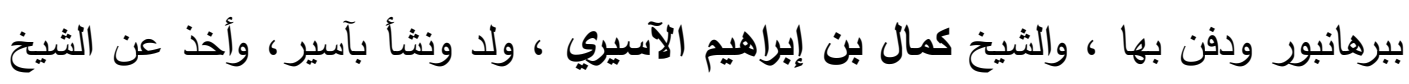

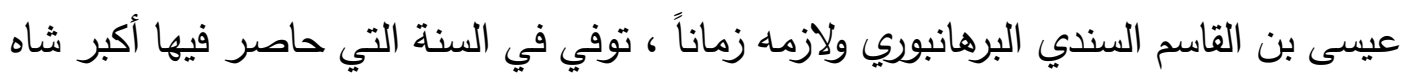
قلعة آسير ، وكذلك الشيخ محمد بن عبد الله السندي ، المشهور بتاج العاشقين ، ولد ونشأ بمدينة برهانبور ، وقرأ المنطق والحكمة ، والفقه والأصول ، وصار بارعاً في العلم والمعرفة وأفاد 
الناس مدة طويلة بمدينة برهانبور، ثم لما دخل أكبر شاه مدينة برهانبور اتهمه بالبغي وأمر بحبسه ، فذخل في السجن ولبث فيه زماناً ، ثم شفع له بعض الأمراء فخلى سبيله (rأ) . وغيرهم الكثير من العلماء من أبناء خانش الذين تربوا ونشأوا بخاندش وتعلموا العلم بها وعلموه - لغيرهم

\section{الصوفية في خاندش في عه الفاروقيين}

قيل إن الصوفية اختلفوا في طرق الرياضة وتعليمهم في إماتة القوى الحسية وتغذية الروح - طبقا لأفكارهم ومعتقداتهم - فانشعبت منهم طرق كثيرة أشهرها القادرية للسيد عبدالقادر الجيلاني ، والطريقة السهروردية للشيخ شهاب الدين السهروردى ، والطريقة الجشتية

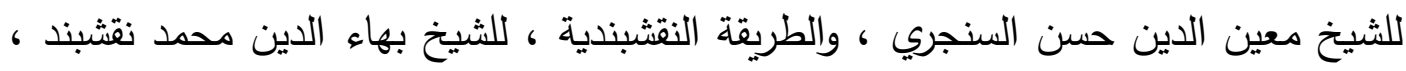
والقلندرية للشيخ قطب الدين الجونبوري ، والثطارية للثيخ عبدالله الثطار الخراساني ، وغيرها من الطرق الصوفية وكل من الطرق المذكورة وصل إلى الهند ، ونشأ ونمى ودخل فيه خلق ولق ولئ

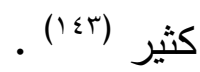

كان سلاطين الفاروقيين في خاندش رعاة عظماء للعلم ولقد أظهروا اهتمامًا شديدًا بالتعليم الديني وبشكل خاص الصوفية ، وسرعان ما أصبحت عاصمتهم برهانبور مركزًا مهما للدراسات الإسلامية والتصوف ، فأدى ذلك إلى توافد عدد كبير من شيوخ الصوفية المشهورين إليها من مختلف أنحاء الهند وخارجها واستقروا في برهانبور وقدم لهم الفاروقيون كل عوامل الاهتمام خاصة الجوانب المالية . كانت بداية تعامل الأسرة الفاروقية مع علماء التصوف من خلال تعاملهم مع الثيخ

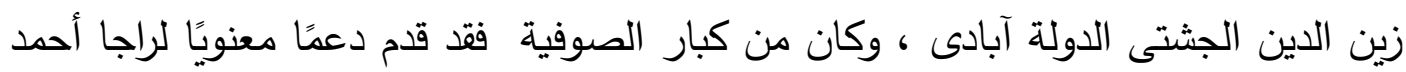
عندما تمرد على سيده البهني وأصبح راجا أحمد تلميذاً له وحافظ خلفاؤه على التقليد ذاته اته

استمر الفاروقيون يقيمون علاقات قوية مع مشايخ الصوفية فقد ذكر الآصفي في كتابه

أنه كان هناك علاقة قوية وصلة كبيرة بين عادل خان الثاني وبين القطب المشهور - على حد

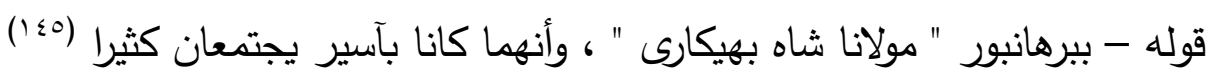

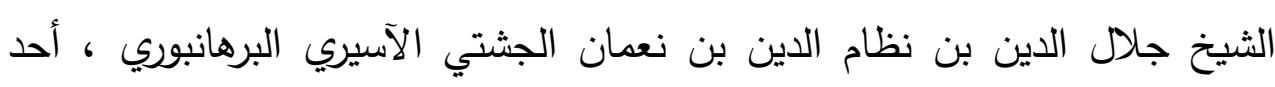
المشايخ الجشتية ، ولد ونشأ بآسير ، وأخذ عن أبيه وتولى الثياخة بعده ، مات سنة 901 


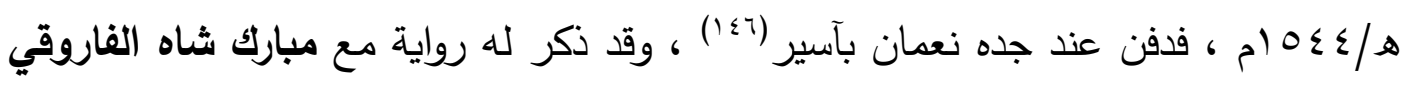
فقد كان مبارك شاه من أشد المعبيين باه وكان لديه إيمان قوي بقدراته وكراماته ، يقال أنه

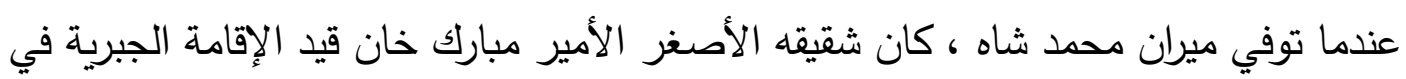
أحد الحصون ووضع النبلاء على العرش أحمد شاه الابن الصغير للحمد شاه وقرروا اكحال

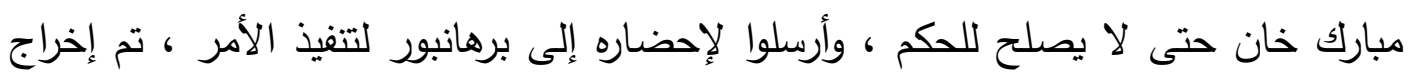

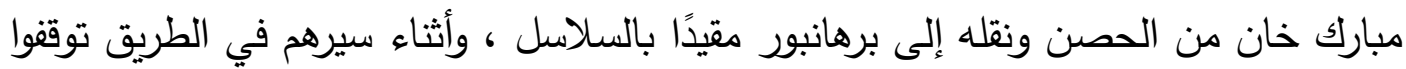

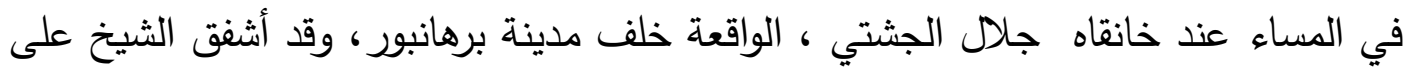
الأمير البائس وصلى الله لكى يُطلق سراحه ، وأخبر الأمير ألا يقلق لأن أيام محنته قد ولت ،

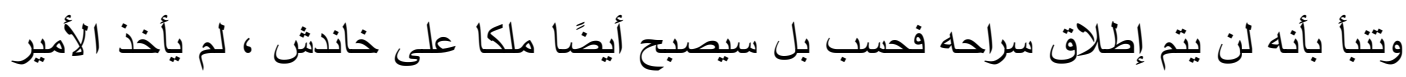

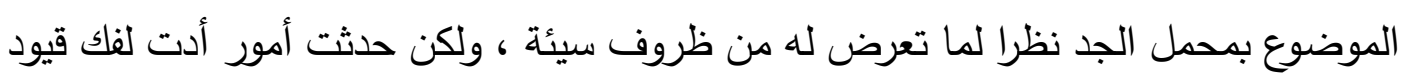
مبارك وهرع على الفور إلى القصر الملكي ، واستولى على العرش ، ومن حينها ظل ميران

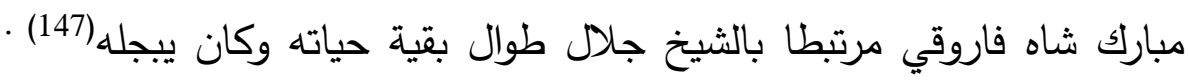

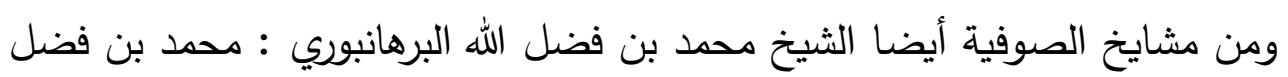
الله بن صدر الدين الجونبوري ثم البرهانبوري ، ذكر أنه كان من ذرية سيدنا أبي بكر الصديق رضي الله عنه ، ولد ونشأ بكجرات ، وتوفي والده في صغر سنه ، ثم سافر إلى الحرمين الثريفين واقام بها اثنتي عشرة سنة ، ثم عاد إلى أحمد آباد وتزوج بها ، ثم سكن بمدينة برهانبور وعكف على الدرس والافادة ، وكان من أسياد الصوفية وحجتهم ، وكان من أكابر القائلين

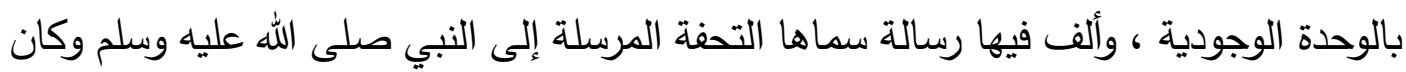
فراغه منها في سنة تسع وتسعين وتسعمائة ، واعتذر فيه عما يقع من محققي الصوفية من الثطح الموهم خلاف الصواب وكانت وفاته سنة تسع وعشرين وألف ، وقبره بمدينة برهانبور

ومنهم الثيخ عبد الستار البرهانبوري : عبد الستار بن عيسى بن قاسم بن يوسف

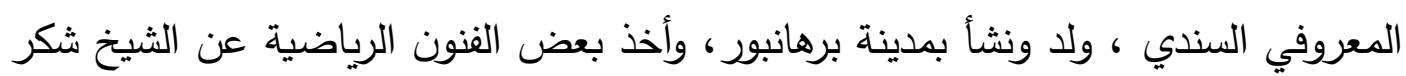

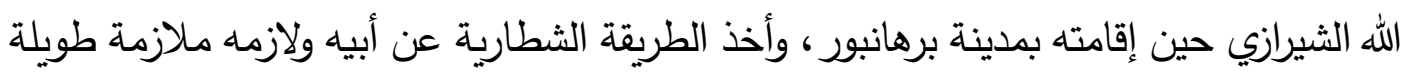
وتصدر للتدريس بعده (9ء () . 


\section{الهنسسة المعمارية}

كان الفاروقيون رعاة عظماء للفن والثقافة وفي ظل رعايتهم القديرة والحميدة ، حققت خانش درجة غير مسبوقة من التطور الفني والثقافي وشهدت تثييد العديد من المباني المهيبة والقصور الملكية والمساجد والأضرحة والخانقاوات والحصون ، ومنها المسجد الجامع الذي بناه

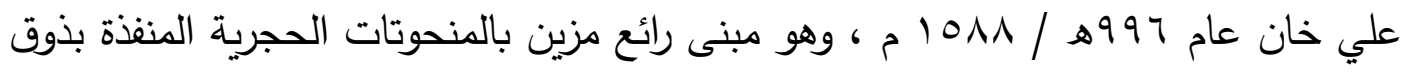

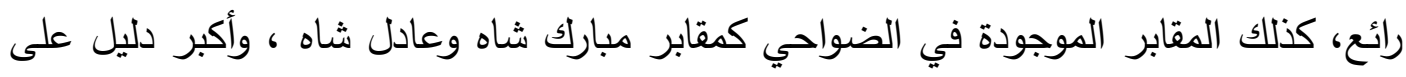
التقدم المعماري والهندسي بخاندش في عهد الفاروقيين نظام إدداد المياه إلى مدينة برهانبور

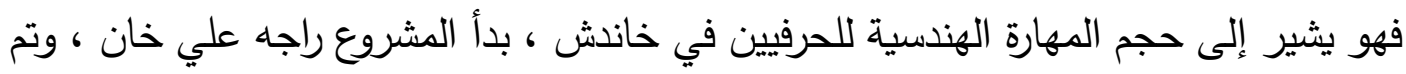

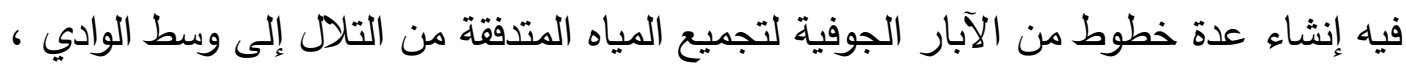

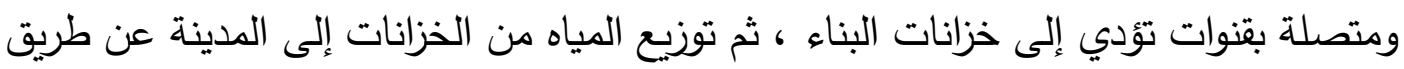

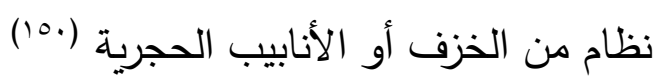
ومع ذلك ، لا يمكن تشكيل فكرة محددة فيما يتعلق بالإنجازات الفعلية للفاروقيين في

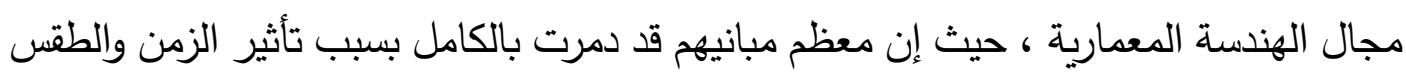

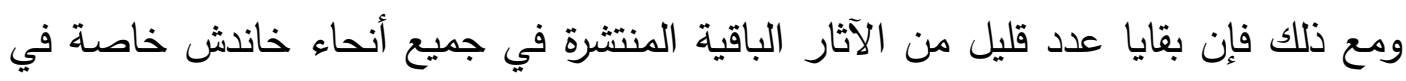

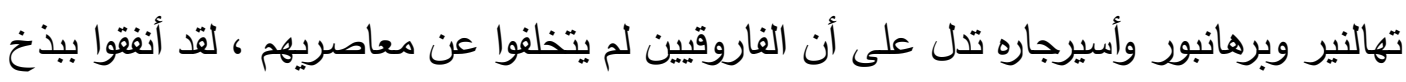

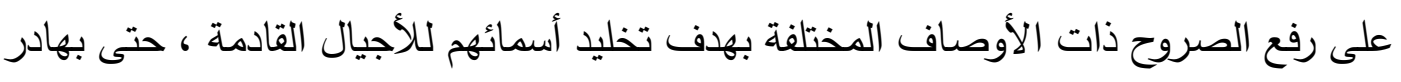
شاه آخر سلاطين البيت الفاروقي كان مهتمًا بأعمال البناء ، فقد بنى لنفسه مدينة أطلق عليها لأنها

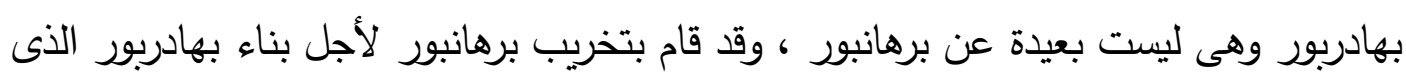

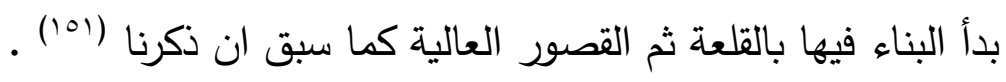

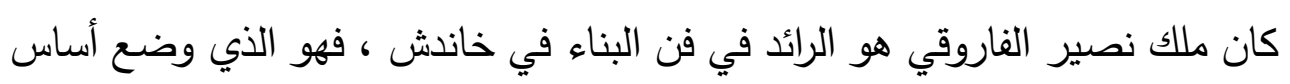

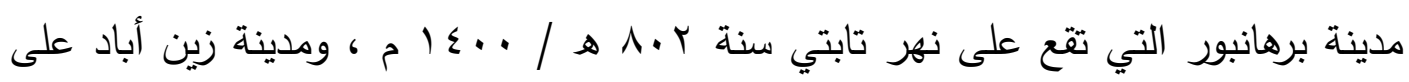

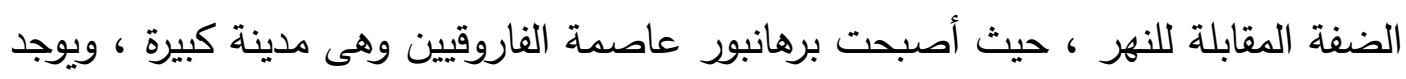

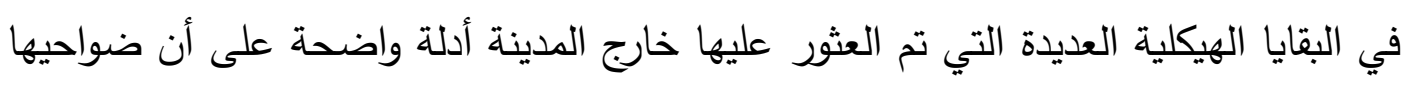

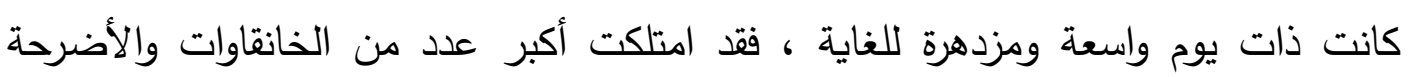

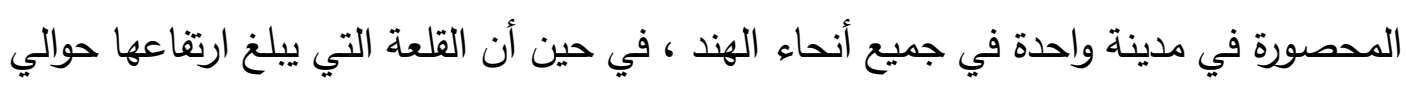
A قدمًا على الضفة اليمنى من تابتي ، تُسب إلى عادل خان الثاني الفاروقي (1or) . 
تم بناء بعض المساجد في برهانبور من قبل الفاروقيين منها المسجد المعروف باسم

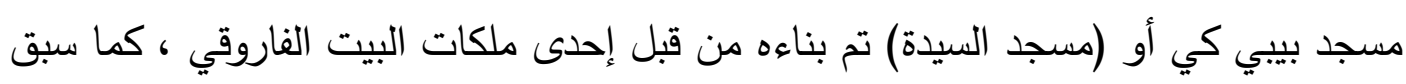

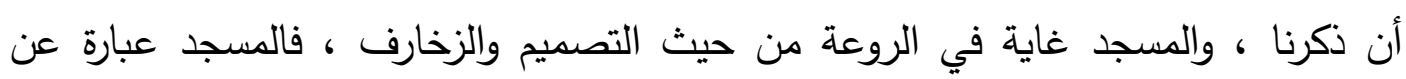

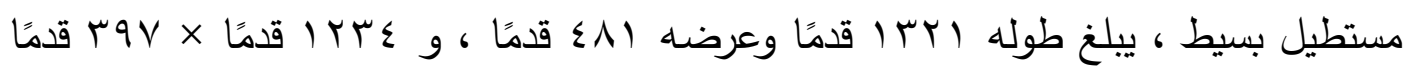

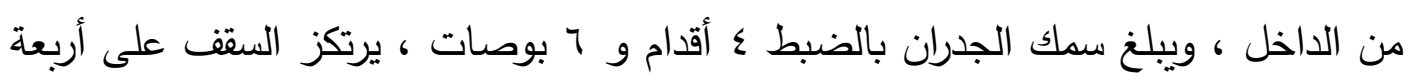

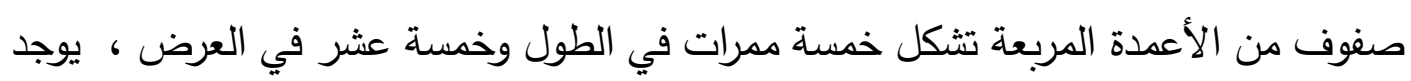

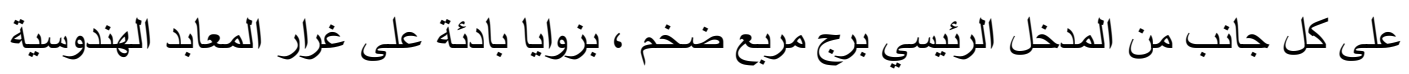

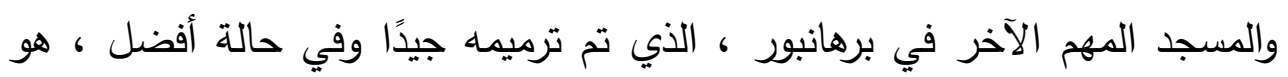

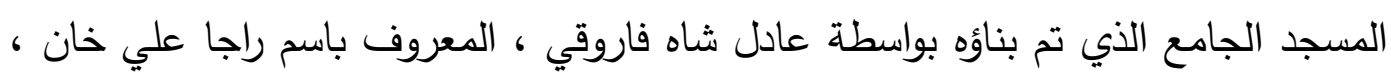

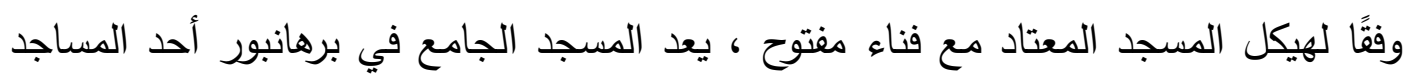

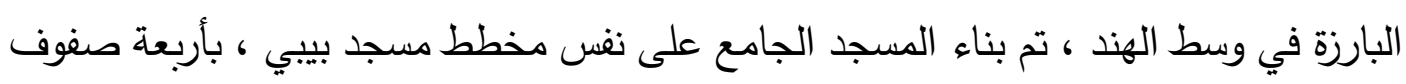

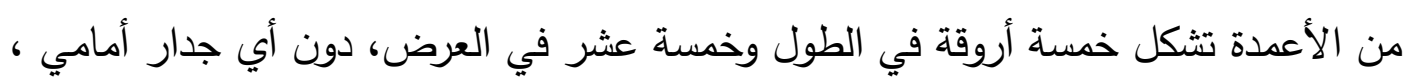

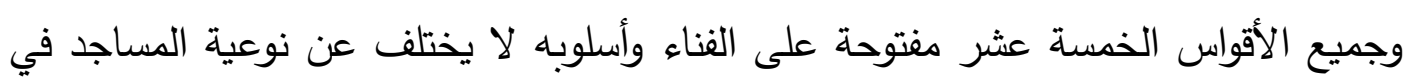
أحمد أباد (108)

من السمات المهمة لعمارة الفاروقيين بناء سلسلة من التحصينات في أماكن إستراتيجية

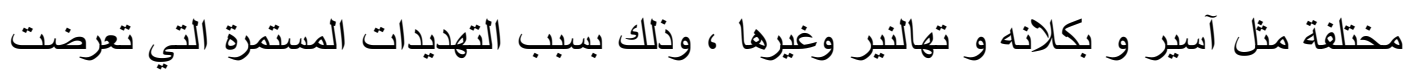

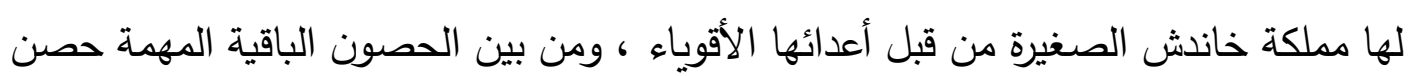

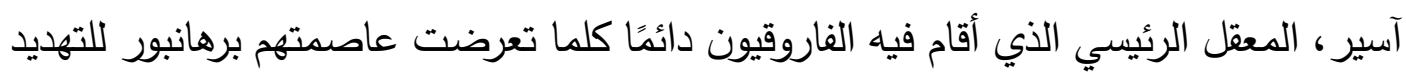

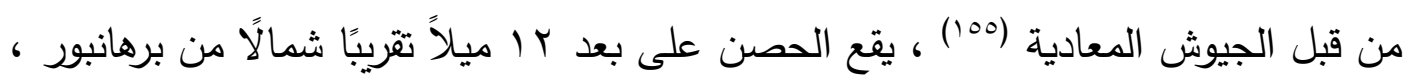

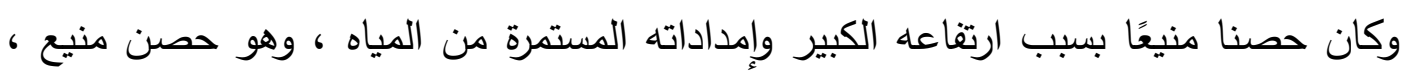

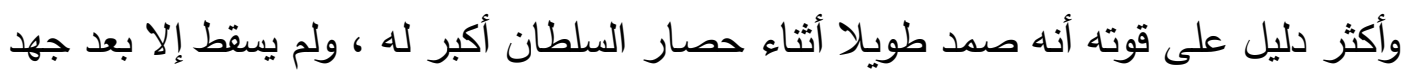

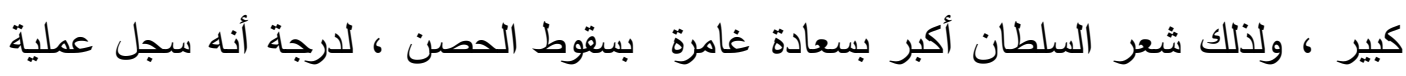

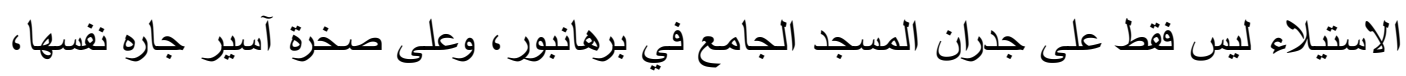

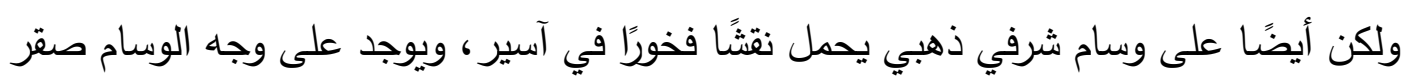
يرمز لانقضاضه على هذا الحصن الثهير وعلى ظهره نقش: الله أكبر (101) . 
بسبب الموقع الجغرافي لخاندش الذى جعلها تحاط بعدد من الممالك القوية ، مثل الكجرات ، ومالوه ، والدكن وغيرها ، فكان من الطبيعي أن يكون حرفيو خاندش قد أخذوا قدرًا كبيرًا من مقدار إلهامهم المعماري من هذه المراكز المؤثرة في فن البناء ، ومع ذلك وفي ظل فيل فئل حكم الفاروقيين ، فان المباني في تهالنير وبرهانبور هى محاولة للتعبير عن شخصية معمارية

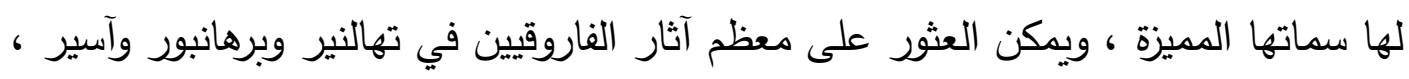
وتقتصر الآثار في تهالنير بثكل أساسي على مجموعة من الأضرحة الملكية ، وهي في المجمل عشرة ، ثمانية منها مبنية بالحجر الأسود المشيد على الطراز الريفي والاثنان الباقيان بالطوب المحروق ، لقد تضررت بشكل أو بآخر ظاهريًا مع تدمير أجزاء من قبابها ، إلا أنها

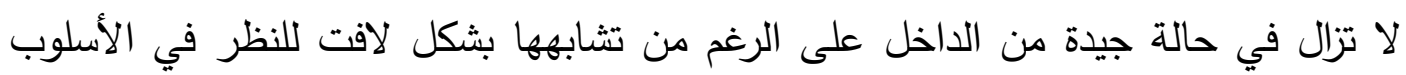

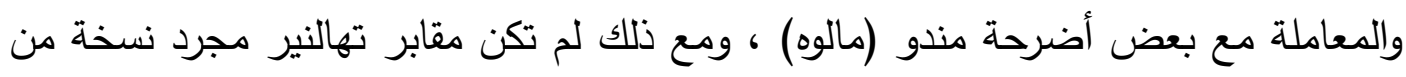
مقابر مالوه حيث توجد اختلافات معينة من حيث الهيكلة والزخرفة على حد سواء ، مما يعني أن هذه لم تكن مجرد نسخ ، ولكن الحرفيين العاملين كانوا يقدمون أفكارًا خاصة بهر ، وأحد

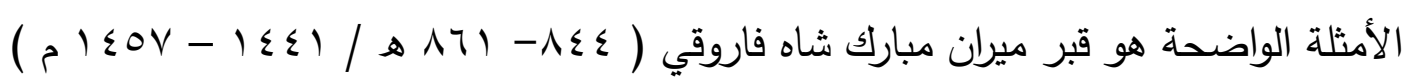
، فالحرفيين تاثروا بالفنون الهندسية لمالوه ولكنهم أبدعوا بطريقتهم الخاصة مئرة (10v) . 


\section{$\underline{\underline{ت}}$}

\section{لقد توصل البحث لمجموعة من النتائج يمكن حصرها في النقاط التالية :-}

استطاع الفاروقيون استغلال فرصة الفوضى التي حدثت في الهند في نهاية عهد الأسرة التغلقية بدهلي وتمكنوا من الاستقلال بمنطقة صغيرة وقاموا بجهود كبيرة لتوسعتها حتى

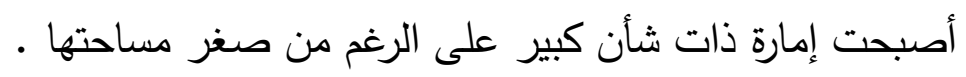
تمكن الفاروقيون على مر تاريخهم من إقامة علاقات قوية مع الإمارات الأخرى سواء المجاورة لهم أو البعيدة عنهم وكانت علاقاتهم تقوم على مبدأ الندية مع غيرهم من القوى

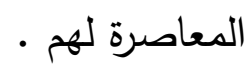
ارتبط الفاروقيون بعلاقة قوية بإمارة الكجرات ، وكانت العلاقة في مجملها علاقة طيبة ، فقد كانت خاندش تابعة للكجرات في بعض الفترات التاريخية تدين لها بالولاء ، وإن كان

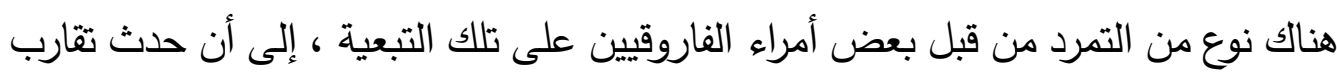
كبير بين الطرفين بسبب المصاهرات العديدة التي جمعت بينهما ؛ إلى أن أصبحت الكجرات

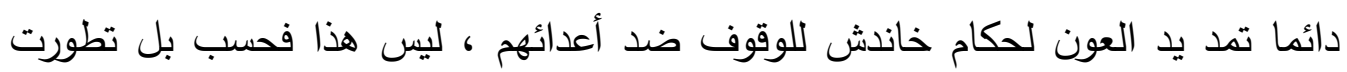
العلاقة لدرجة وضع أحد حكام خاندش على عرش سلطنة الكجرات وهو محمد شاه فاروقي وإن كانت وافته المنية قبل التصيب ، ومنذ ذلك الحين ظلت العلاقة بين الطرفين تقوم على الندية ، وحاول بعض حكام الفاروقيين اعتلاء عرش الكجرات مثل مبارك شاه فاروقى الذى طمع في حكم الكجرات وسعى لذلك أكثر من مرة . كما ربط الفاروقيون علاقات مختلفة مع حكام مالوه تلك الإمارة المهمة في المنطقة وكانت العلاقات في مجملها جيدة حيث جمعهم روح التعاون والمساعدة بين الطرفين، وإن كان هناك فترات قليلة ساءت فيها العلاقة بموجب التغيرات السياسية والمصالح الأعلى • كذلك ارتبط حكام خاندش مع إمارات الدكن مثل البهنيين، وأحمد نكر ، وبرار بعلاقات ونات كثيرة والتي اختلفت وتنوعت حسب المصالح والرؤى السياسية واختلاف الفترات الزمنية على طول حكم الفاروقيين الذى امتد حوالى Or مبنة هجرية كان للفاروقيين دور حضاري لا يقل أهمية عن دورهم السياسي في المنطقة فقد كان لهم نصيب من التجارة وطرقها عبر بلادهم ، كذلك أهتموا بفنون العمارة ،وأهتموا أيضا بالعلم

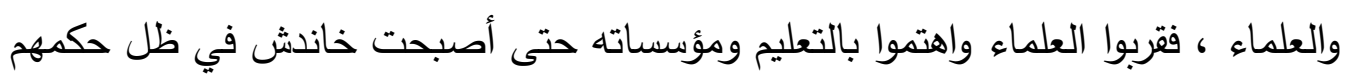


جاذبة للعلماء من كافة البلدان للإفادة والتدريس فيها ، وكان اهتمامهم الأكبر منصب على العلوم الدينية وخاصة التصوف الذى ارتبطوا به وبشيوخه ارتباطا كبيرا منذ نشأت الإمارة وحتى سقوطها . 


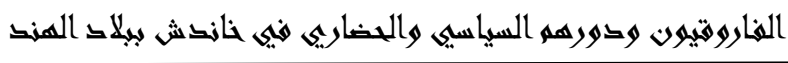

هحمث على همبك إسماعيل

الملاحق

ملحق ( 1 ) جدول بأسماء حكام الفاروقيين في خاندش

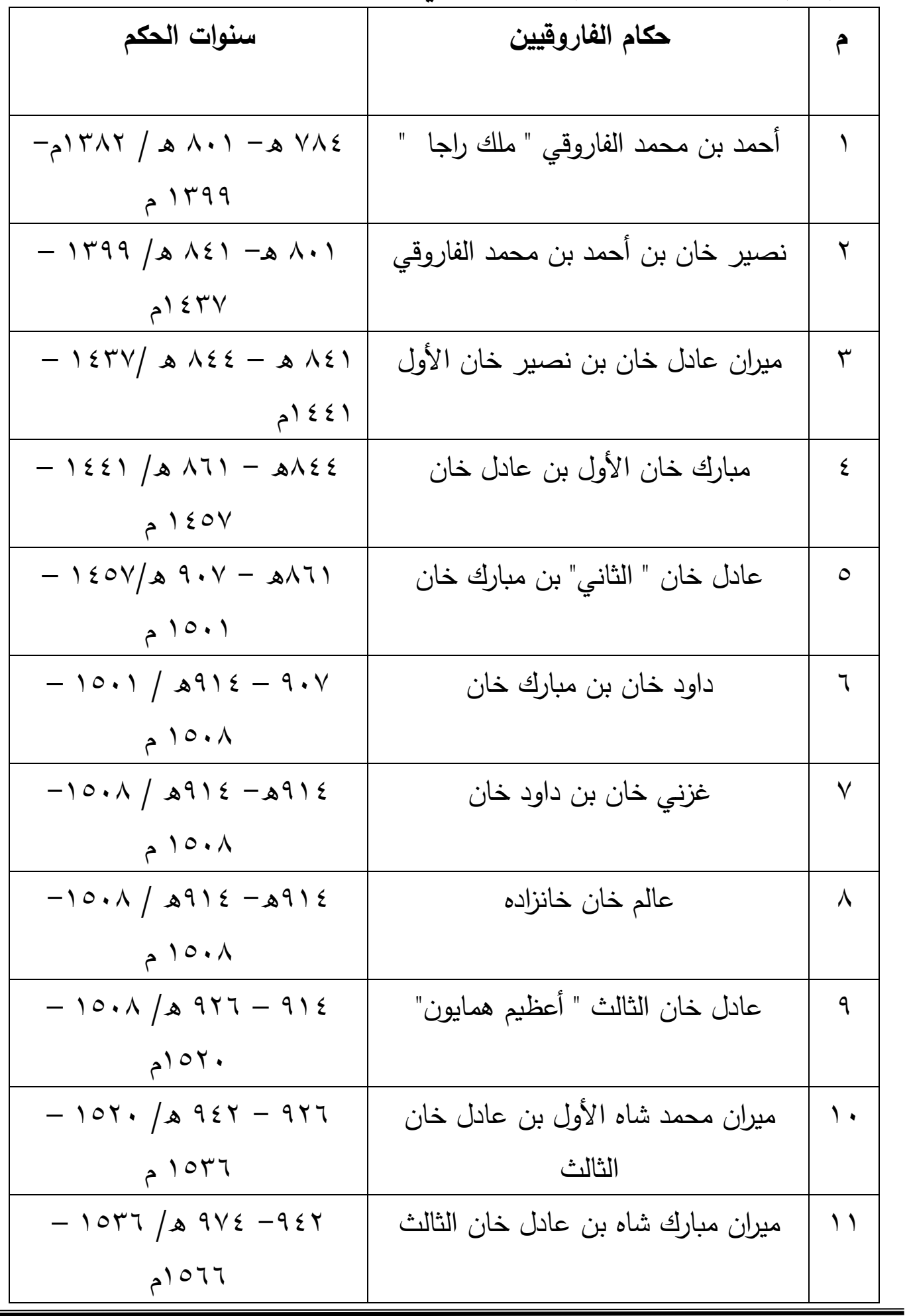

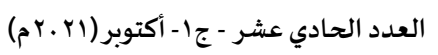

एव।

مجلة الدراسات التاريخية والحضارية المصرية 


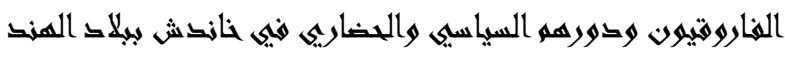

هحمث على همهت إسماعيل

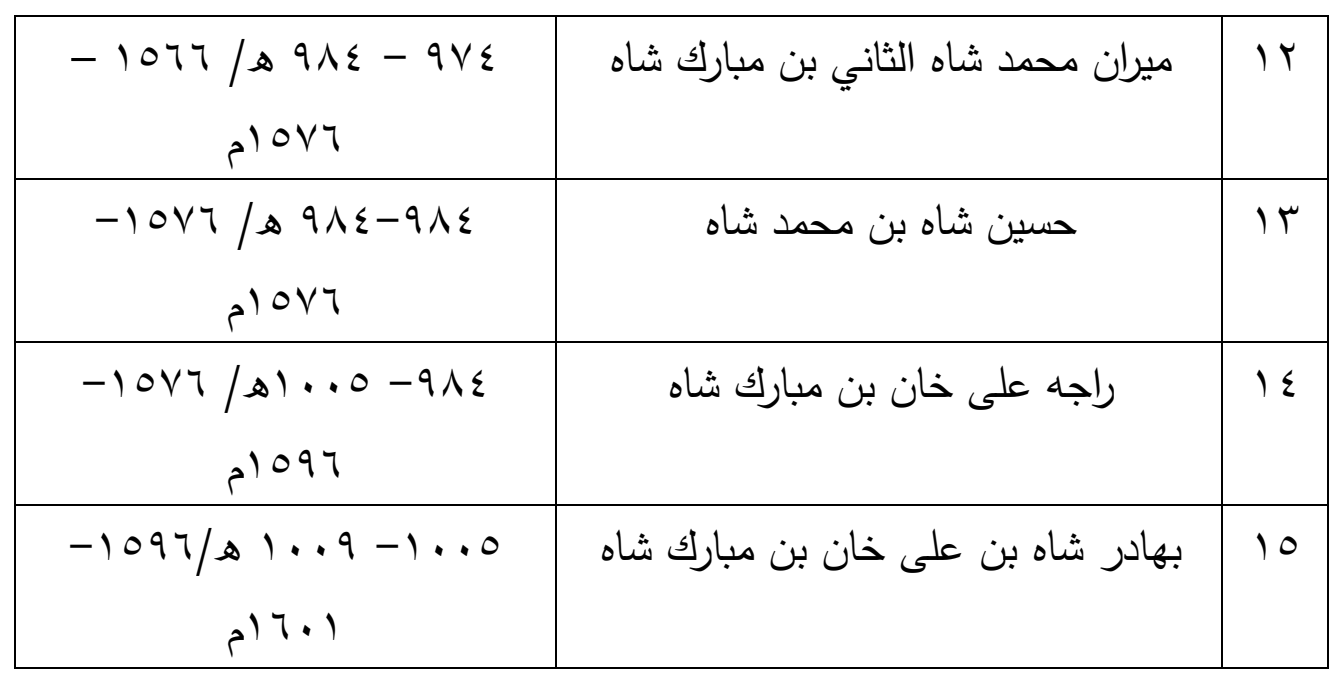

ملحق (Y) مقاطعات الهند

العدد الحادي عشر - ج - أكتوبر (l . r م)

rqr

مجلة الدراسات التاريخية والحضيارية المصرية 


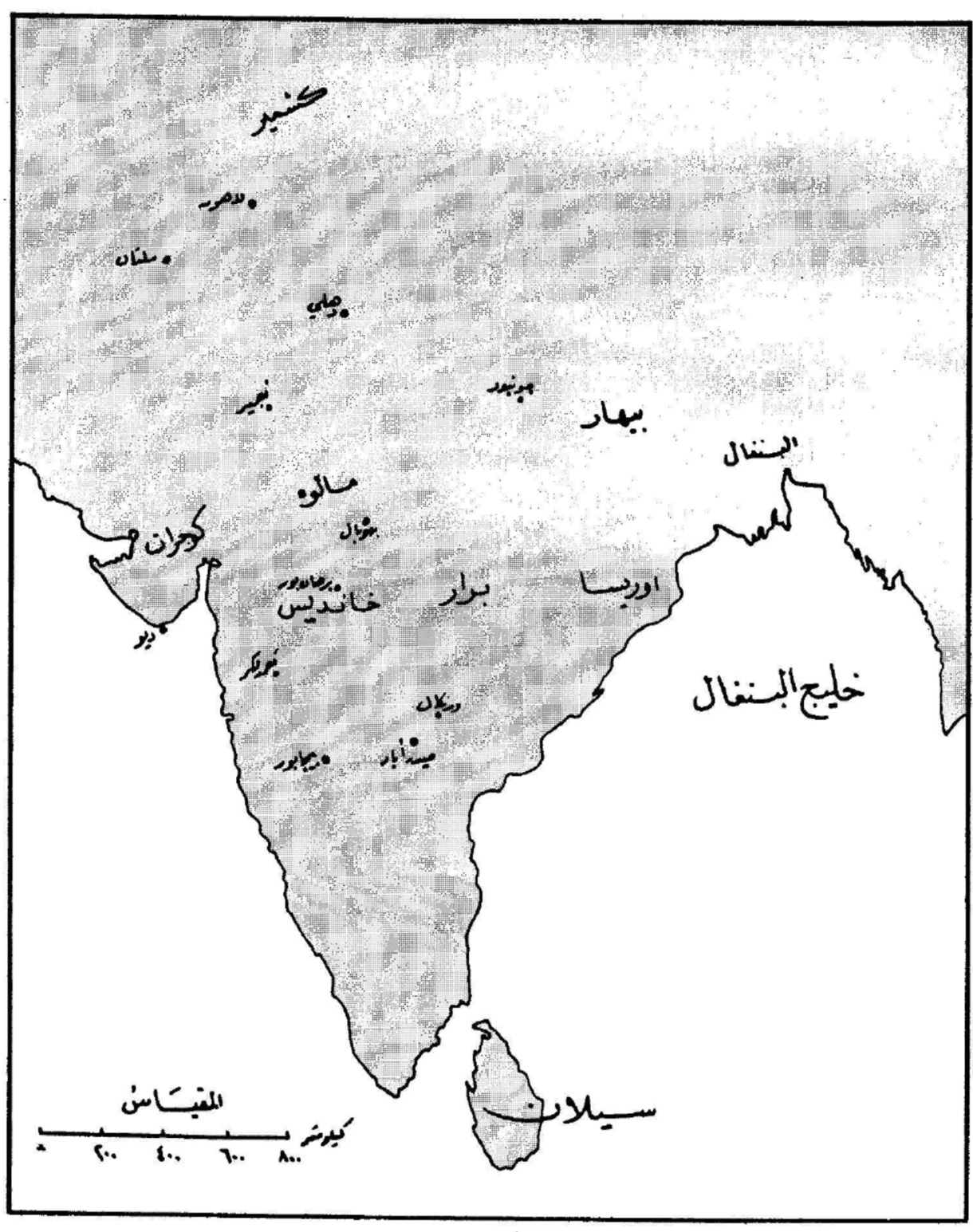

نقلا عن محمود شاكر : " التاريخ الإسلامي العهد المملوكي " ، / ع ع 


\title{
ملحق (r)
}

\begin{abstract}
مقابر في تهالنير لميران مبارك خان وغيره من حكام الفاروقيين بخاندش
\end{abstract}

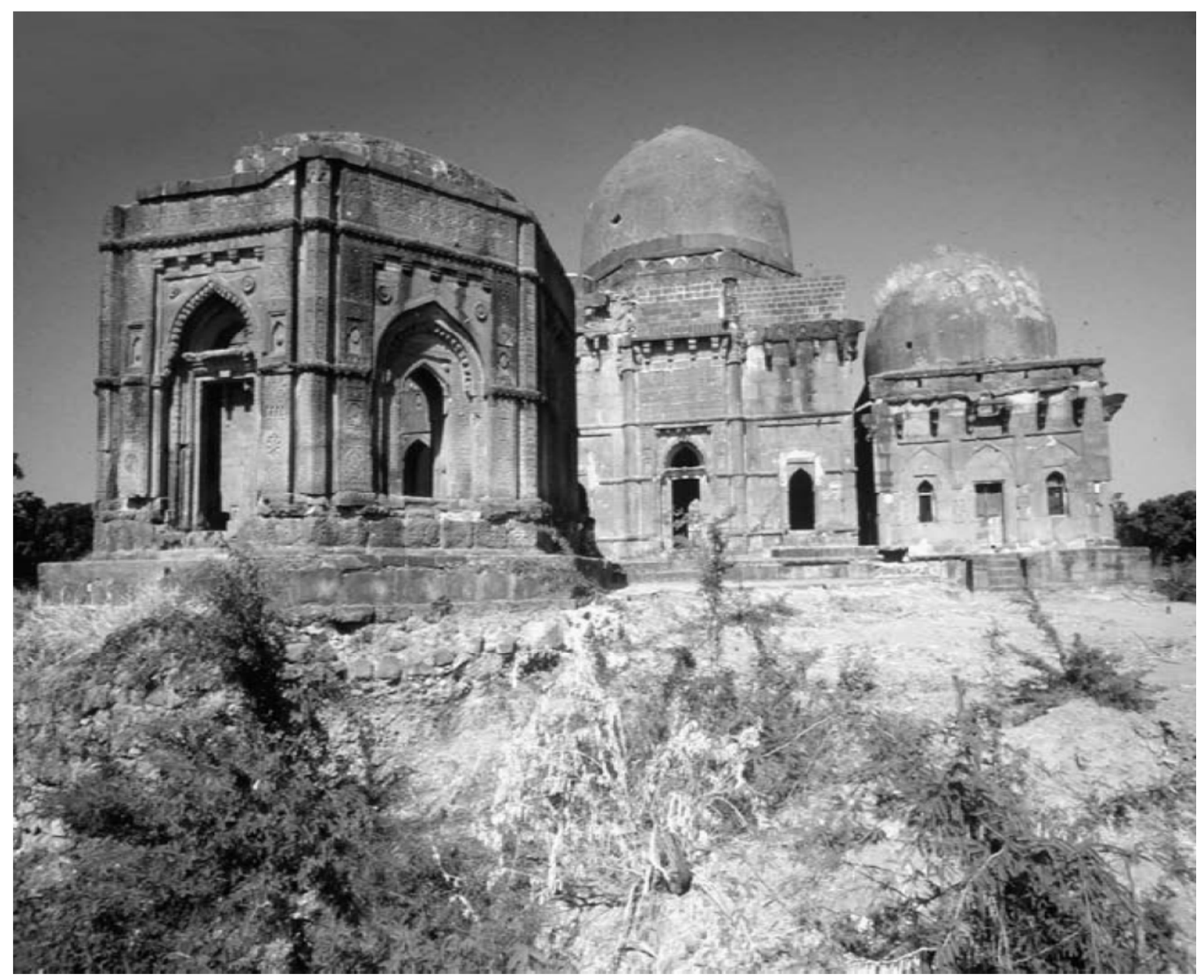

Thalner, tombs of Mīrān Mubārak Khān and others, 15th century

$$
\text { نقلا عن : }
$$

John Burton, :Indian Islamic Architecture ,Edited by : George Michell, LEIDEN . BOSTON, 2008. P 74 . 


\section{ملحق ( ع ) مسجد بيبي كي أو (مسجد السيدة) بمدينة برهانبور}

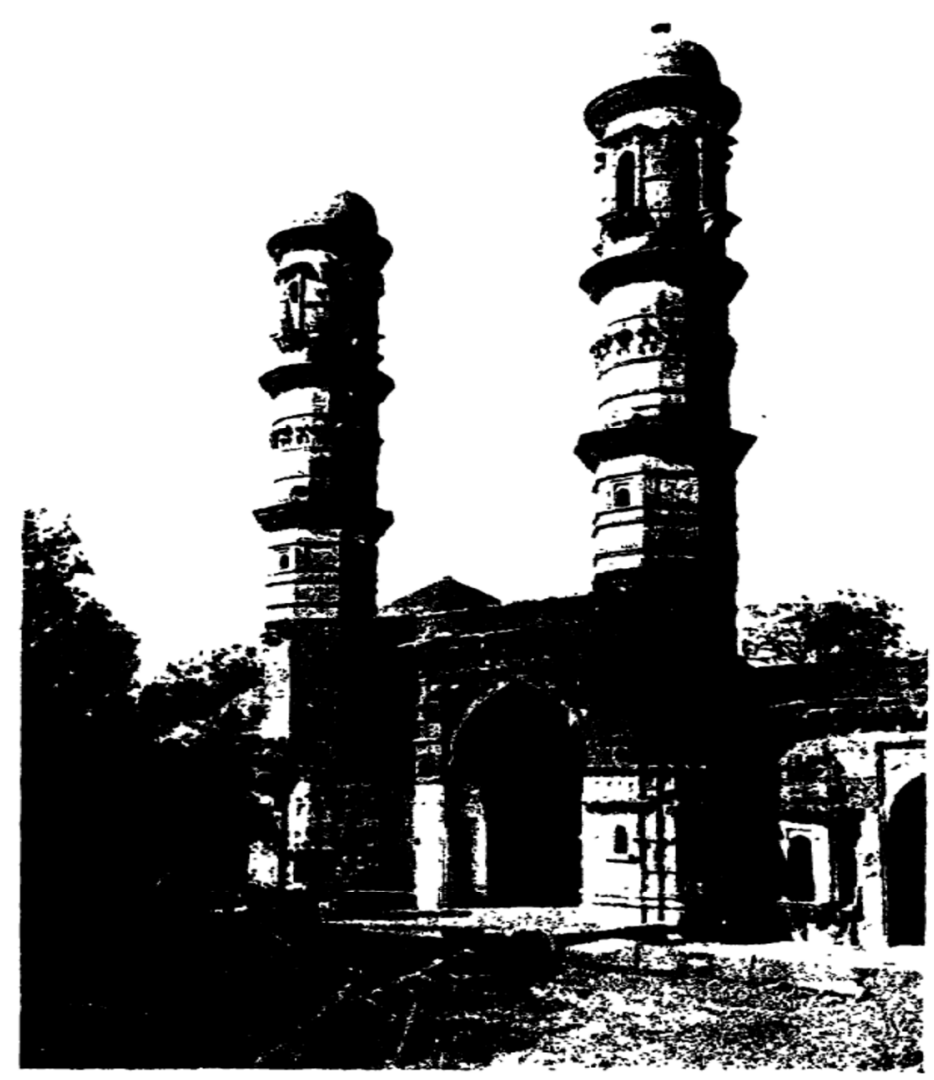

Bibl-k

$\equiv$

نقلا عن :

BROWN, PERCY: INDIAN ARCHITECTURE (The Islamic Period) , p 79 
الهوامش (1) (1) بنو تغلق : التغلقيون : تنسب هذه الأسرة إلى "غياث الدين تغلق" , و هو نركي الأصل من الأتر الك القرونة

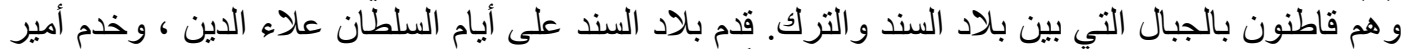

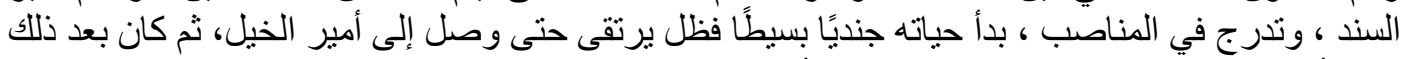

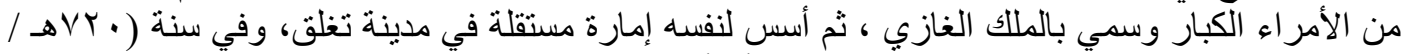

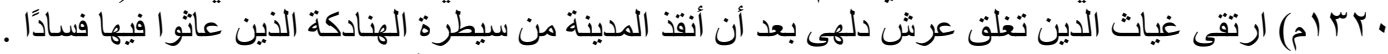

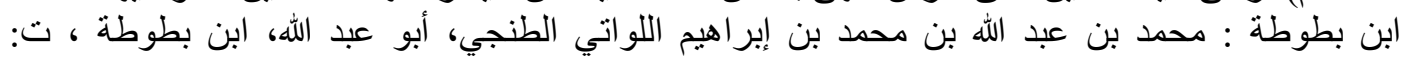
هـVV 9

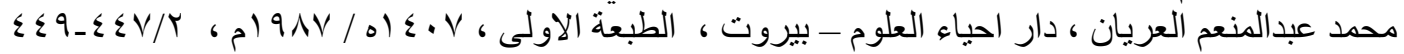

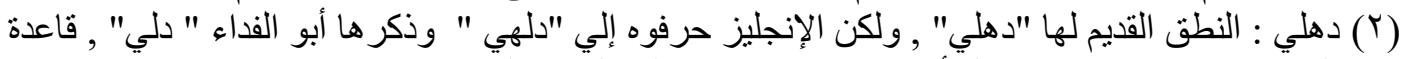

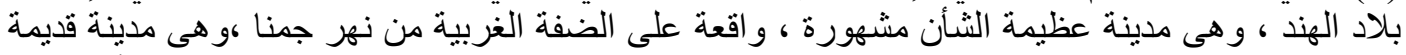

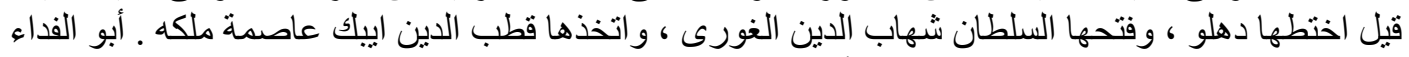

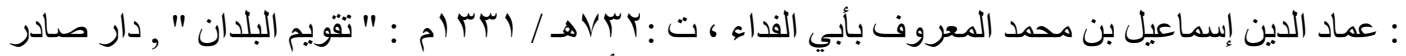

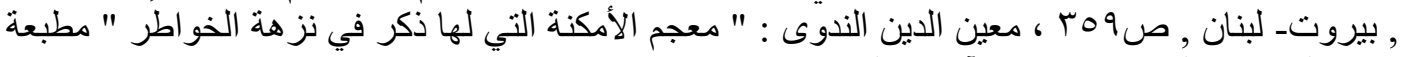

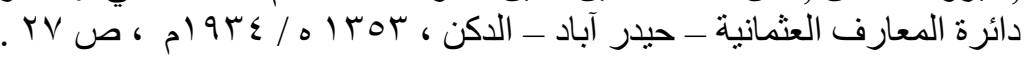

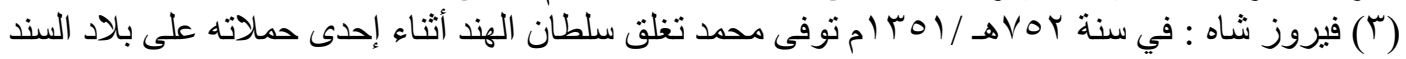

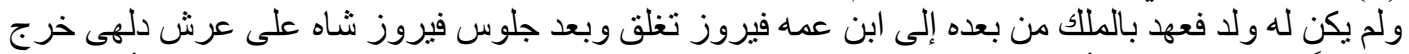

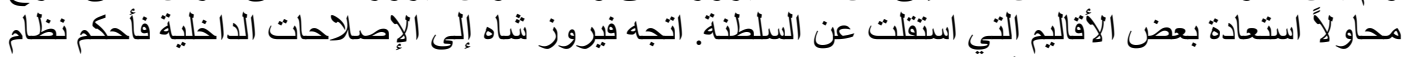

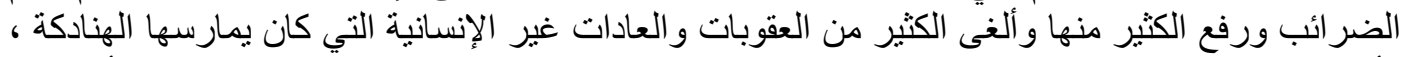

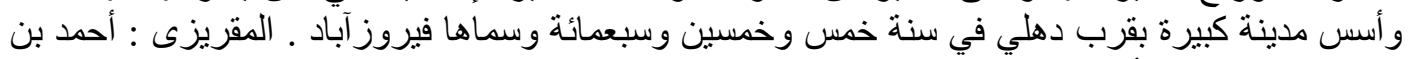

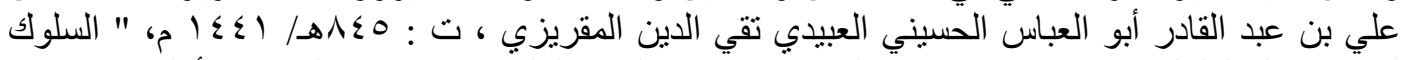

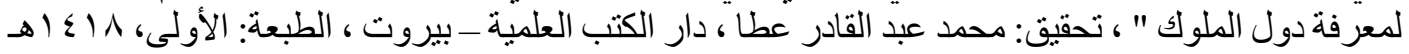

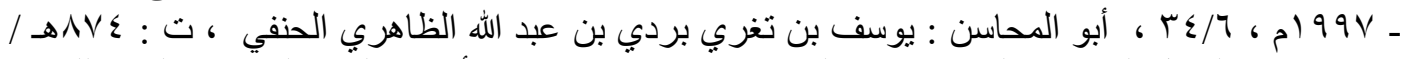

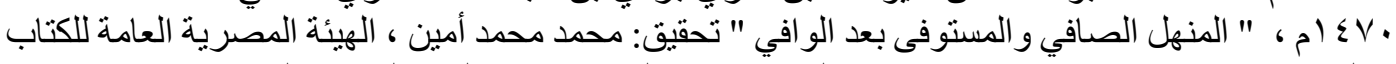

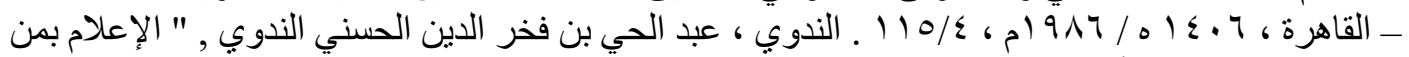

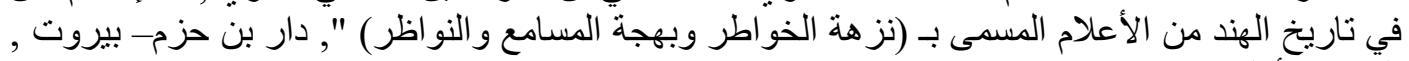

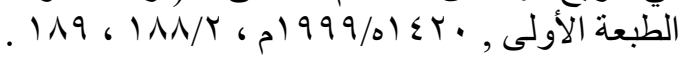

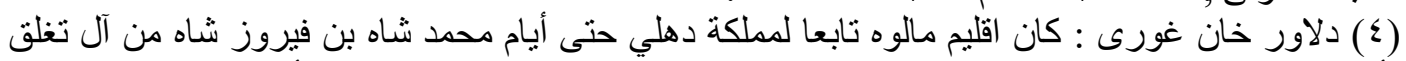

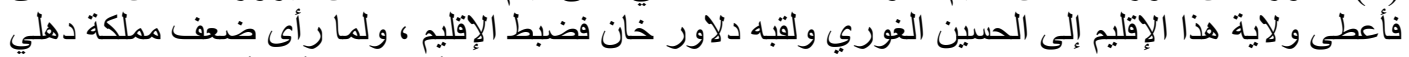

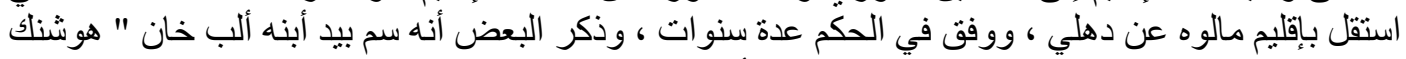

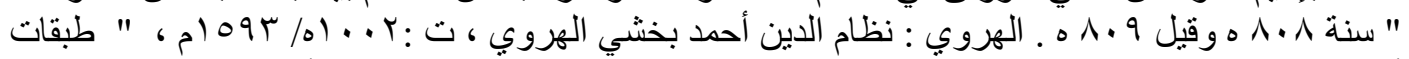

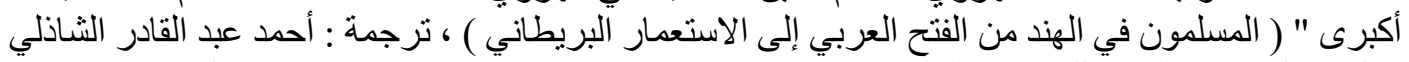

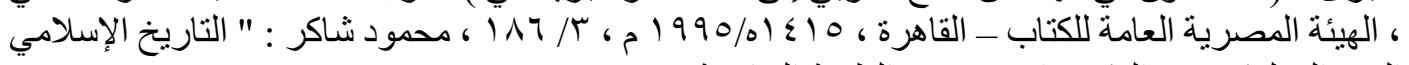

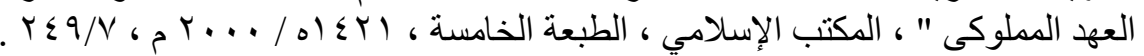

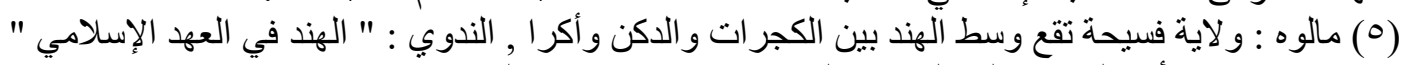

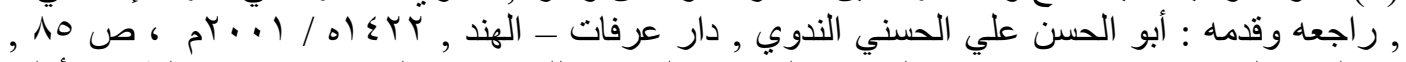

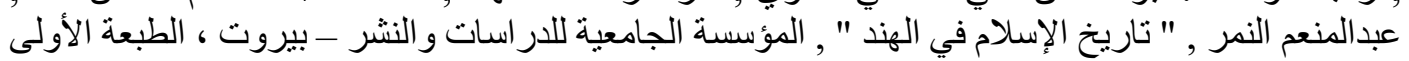

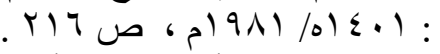

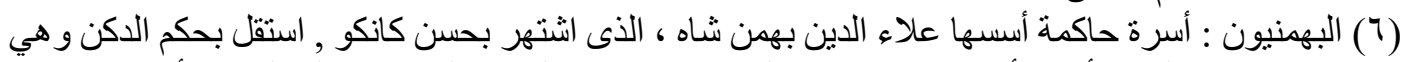

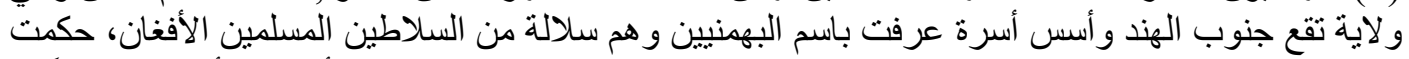

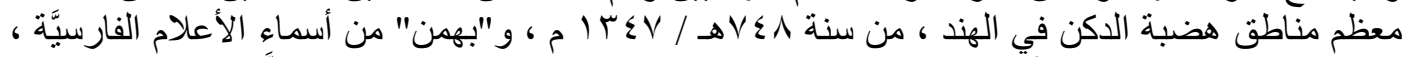

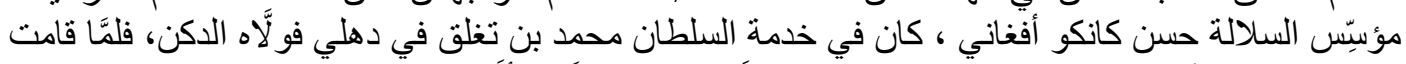

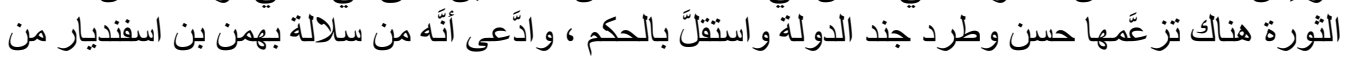




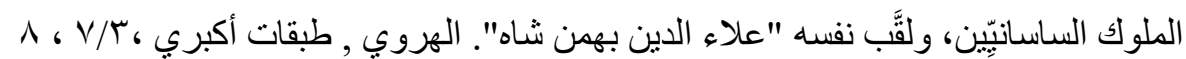

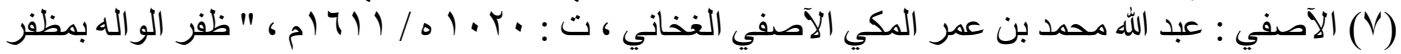

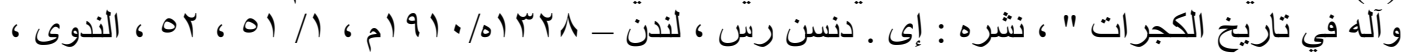

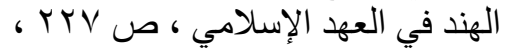

- Briggs, John , History of The rise of the Mahomedan Power in India , London , 1829, vol Iv, p 281

(^) الدكن : أرض الجنوب وتطلق على جنوب الهند ، فهو اسم بطلق على قسم الهند الجنوبي المقابل للقسم

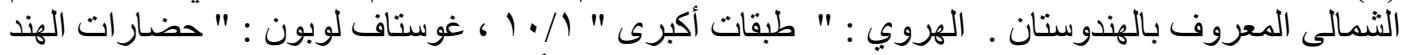

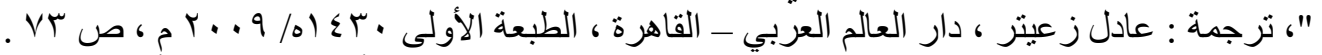

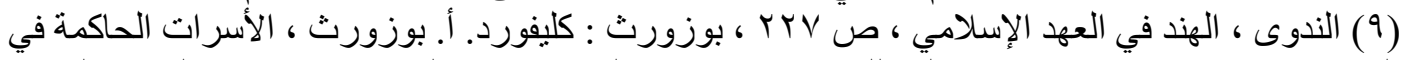

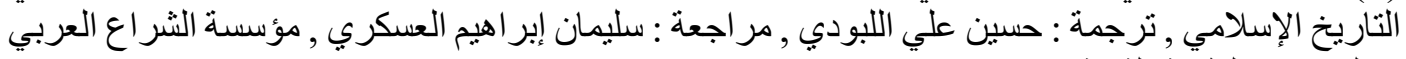

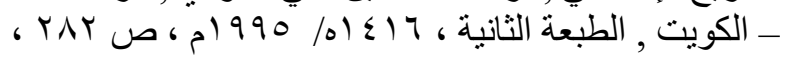

- Briggs, John, History of The rise of the Mahomedan Power in India , vol Iv, P 282

(· · ( ) برار : منطقة في شمال الدكن ، يحدها من الشرق نهر " وردا" ومن الغرب خاندش ومن الجنوب " وان

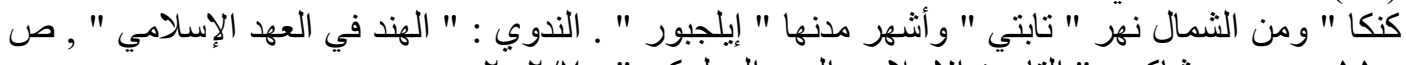

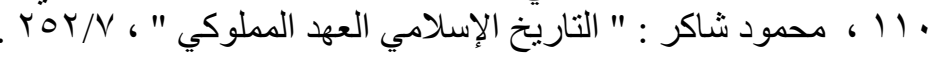

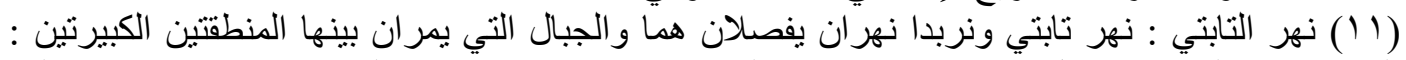

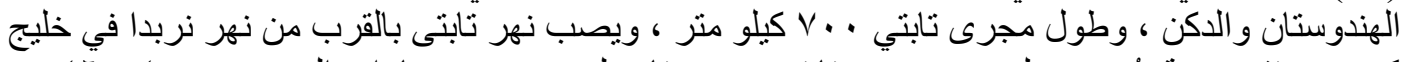

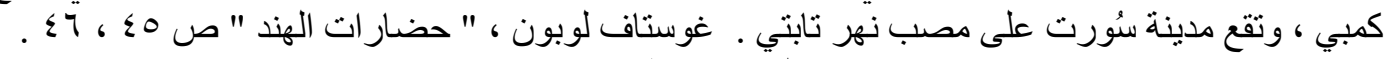

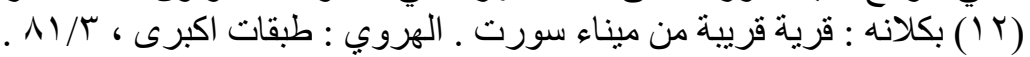

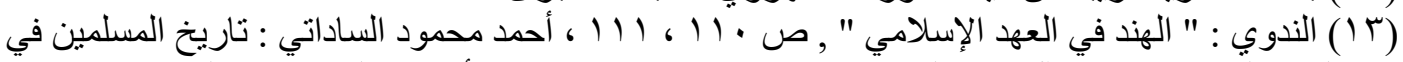

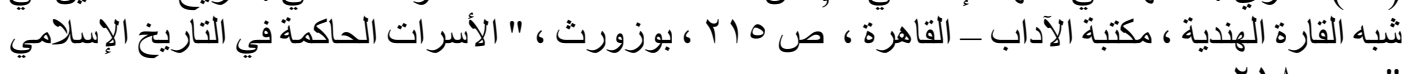

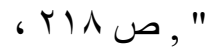

- THE IMPERIAL GAZETTEER OF INDIA,VOL XV, KARACHI TO KOTAYAM , NEW EDITION , AT THE CLARENDON PRESS, OXFORD 1908, p 225,226

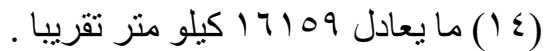

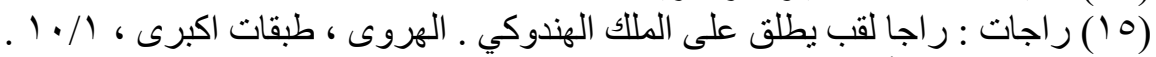

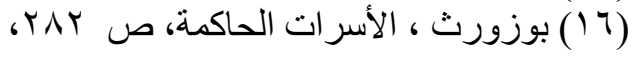

-Briggs, John ," History of The rise of the Mahomedan Power in India , vol Iv, p 298,299

-THE IMPERIAL GAZETTEER OF INDIA, VOL XV, p 225,226

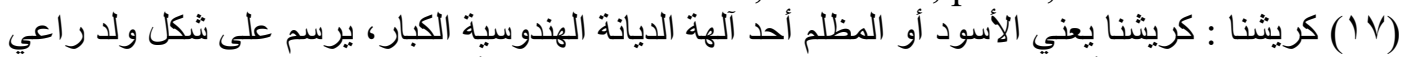

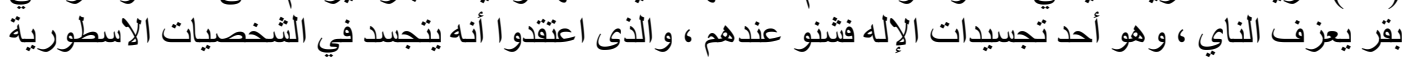

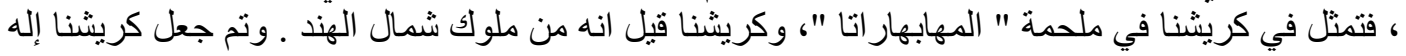

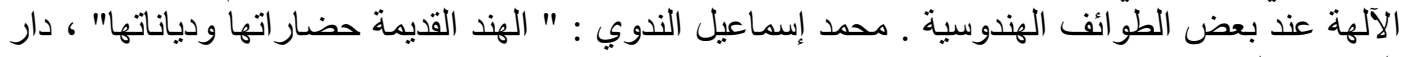

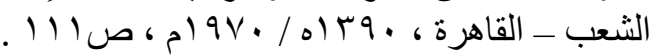

(18) W. F. Sinclair : Rough notes on Khandesh, Indian Antiquary! Vol. 17 (1875), Bomby,P. 108. , Gustav Oppert : " On the Original Inhabitants of Bharatavarsa or India " ORIENTAL PUBLISHERS, PATAUDI HOUSE, DARYAGAN1, DELHI, p 159.160 


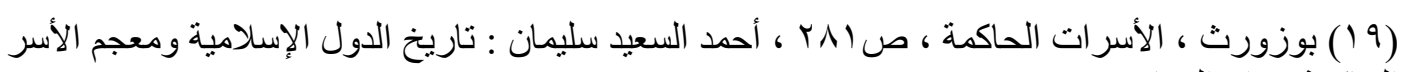

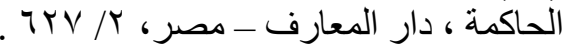

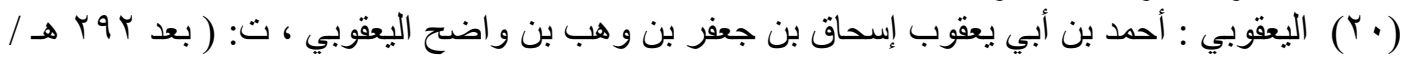

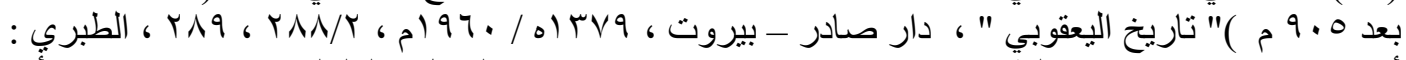

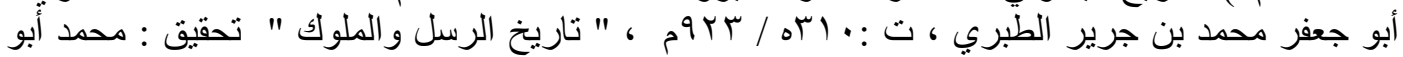

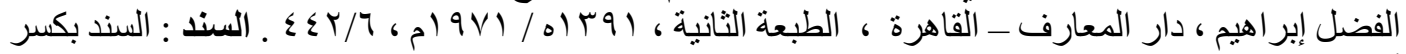

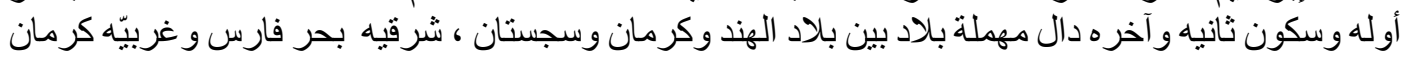

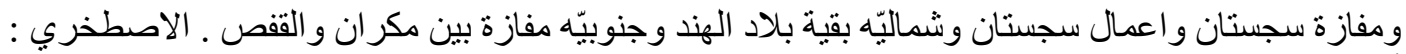

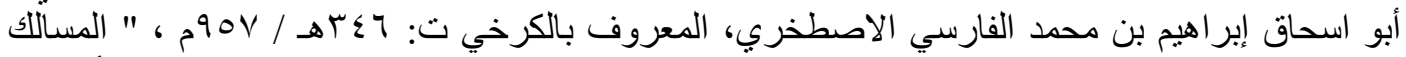

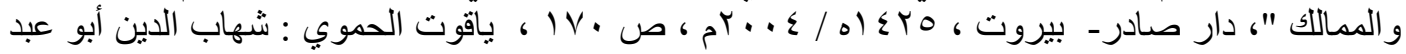

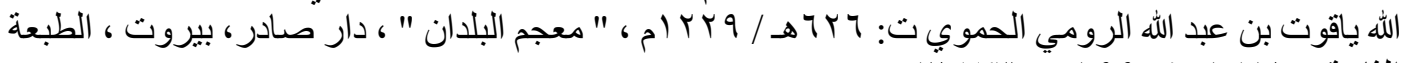

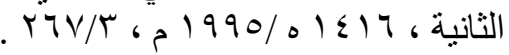

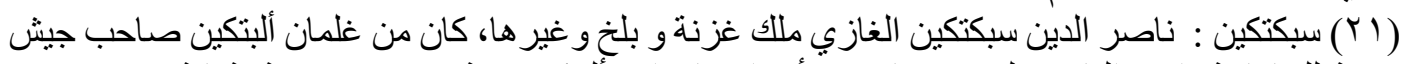

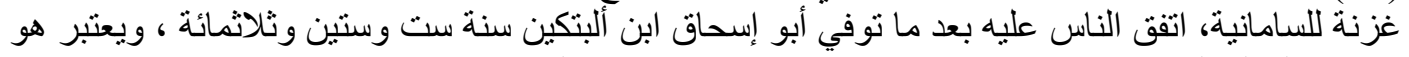

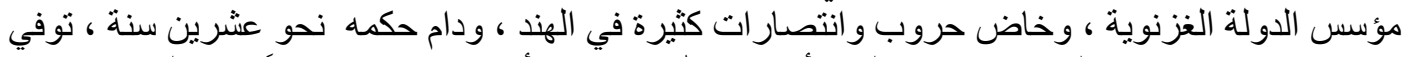

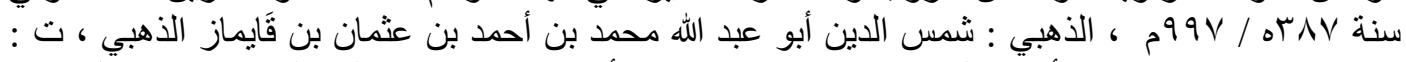

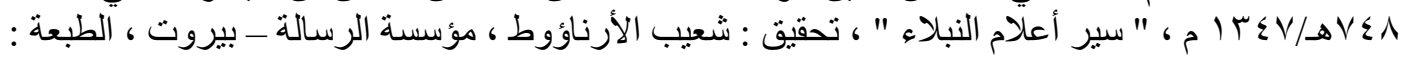

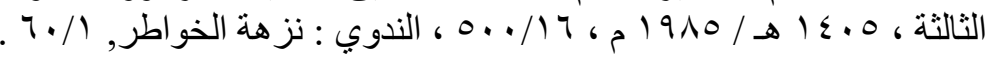

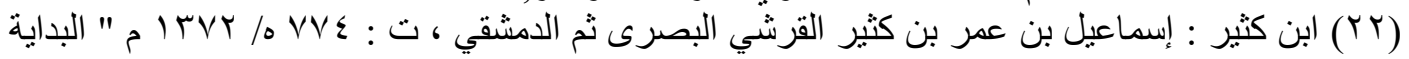

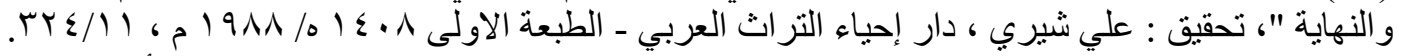

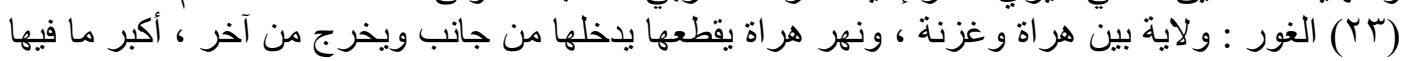

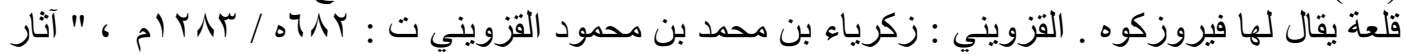

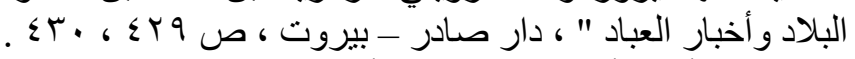

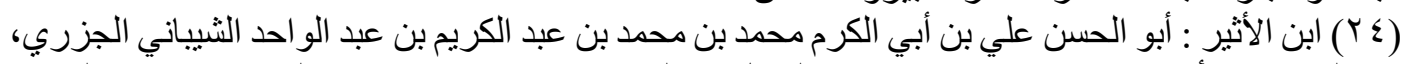

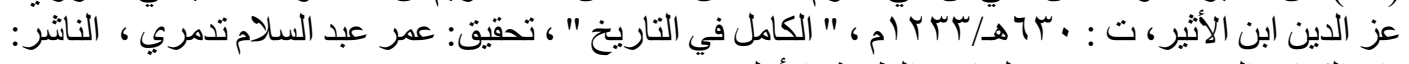

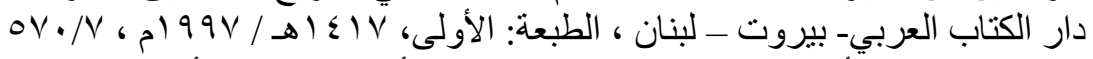



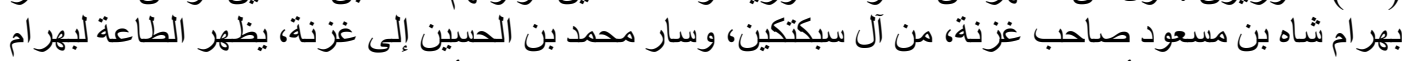

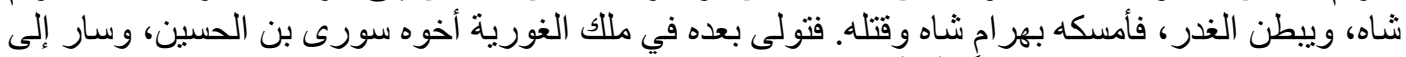

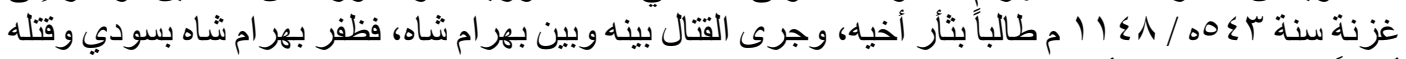

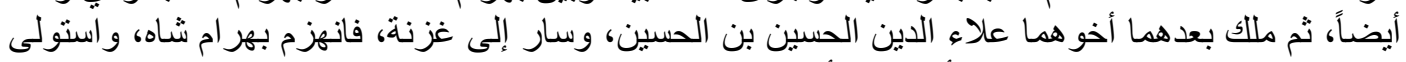

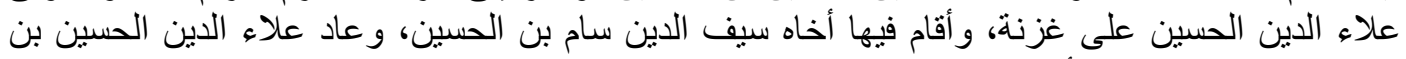

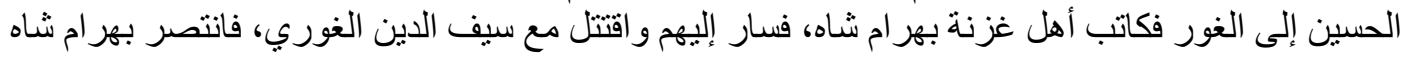



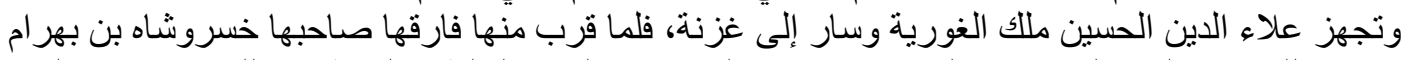

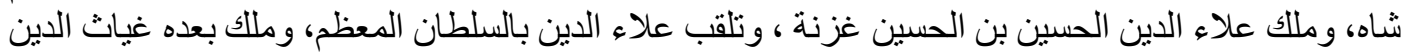

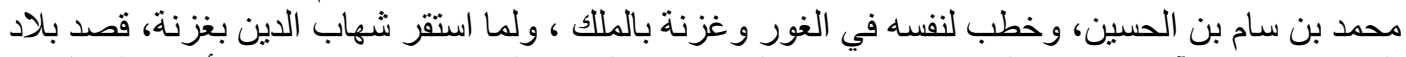

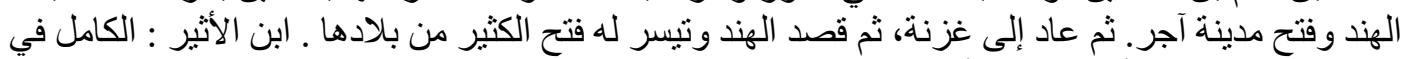

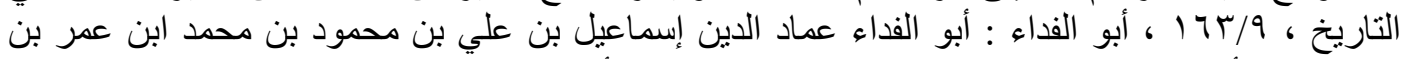

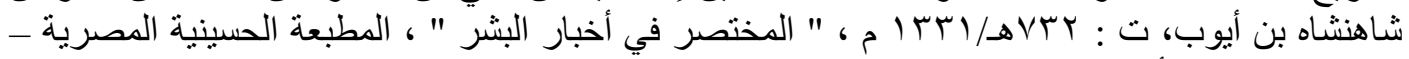

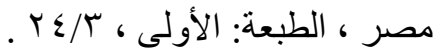

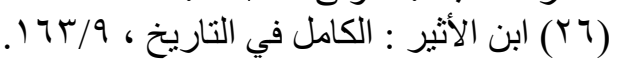




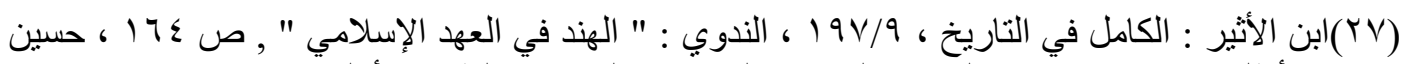

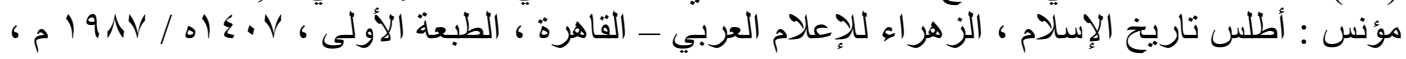

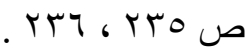

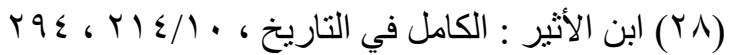

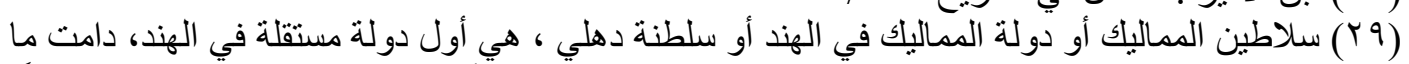

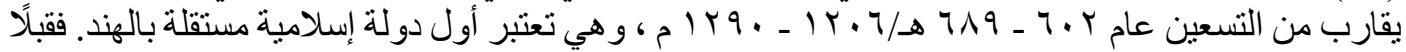

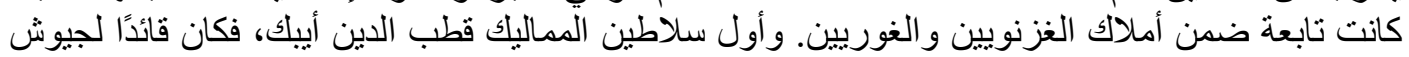

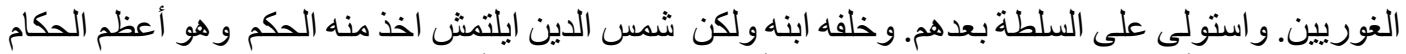

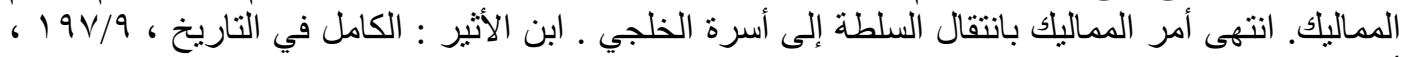

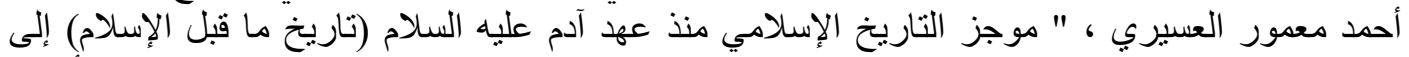

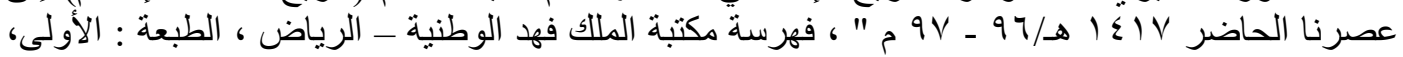

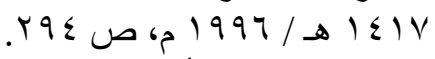

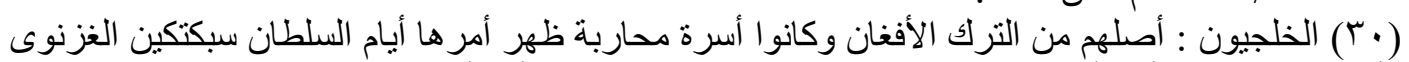

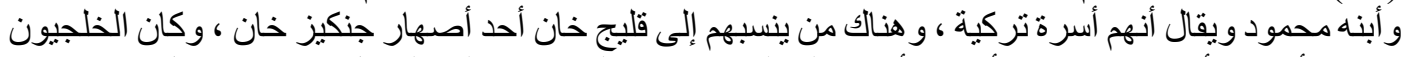

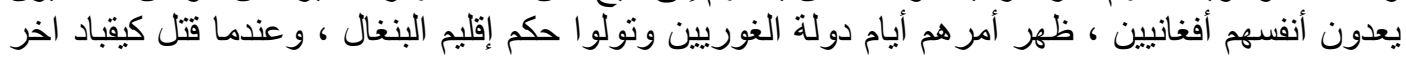

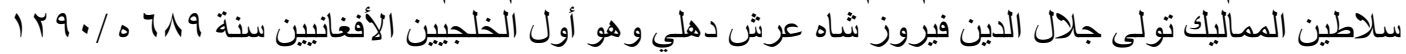

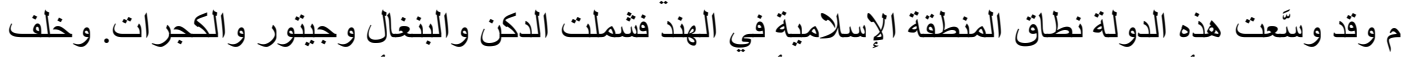

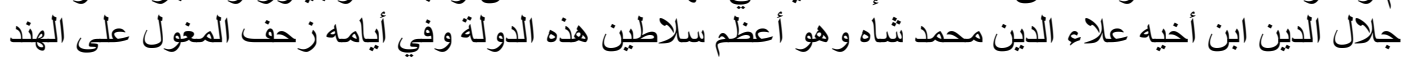

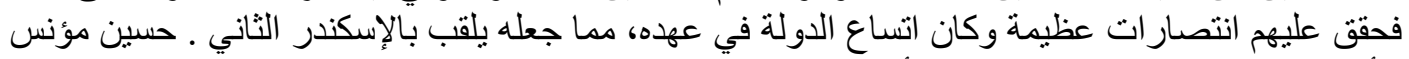

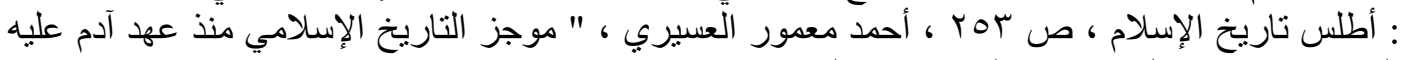

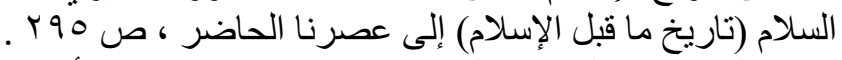

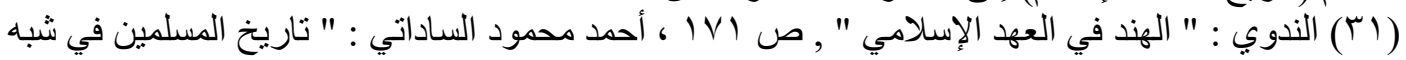

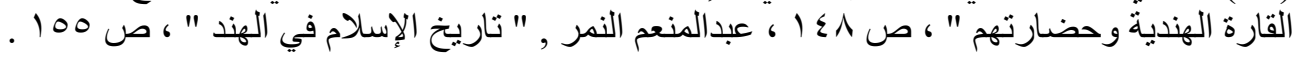

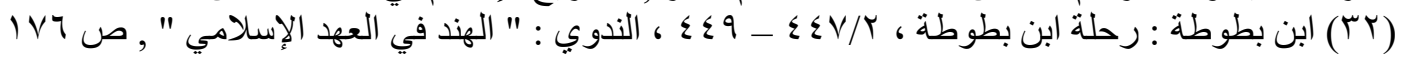

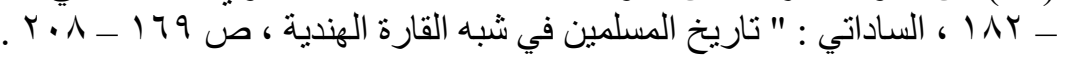

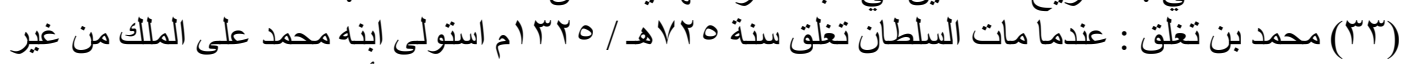

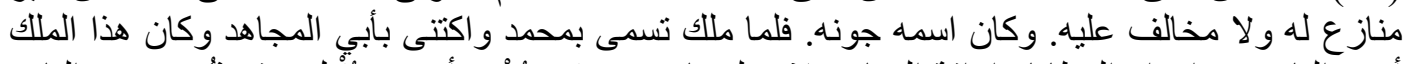

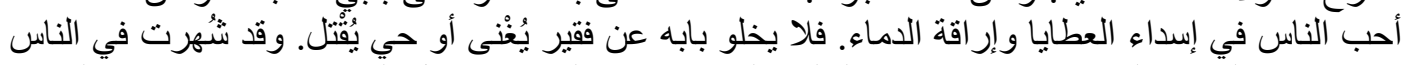

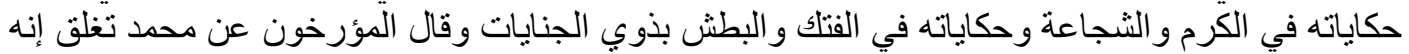

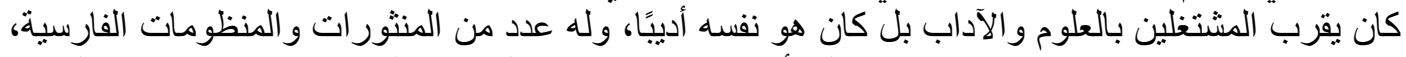

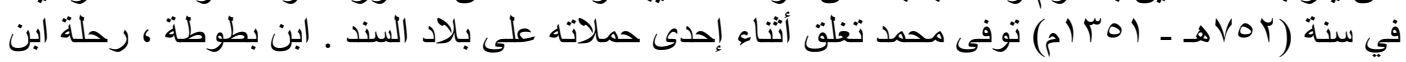

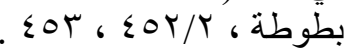
( ع ب) الكجرات : تعد هذه الإمارة ثاني إمار ات الت الهند بعد دهلي , وكانت تضاهيها في الغني , وتضم بلاد منها

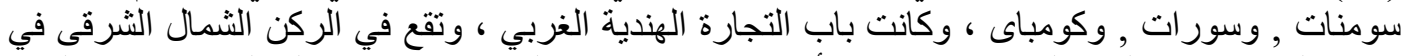

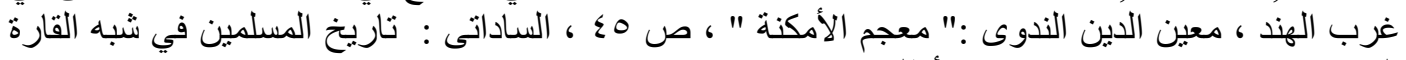

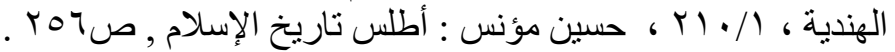

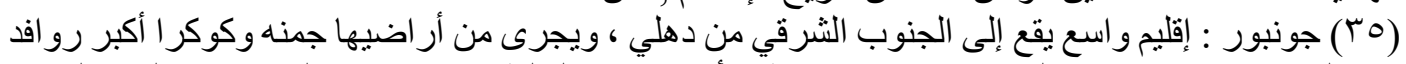

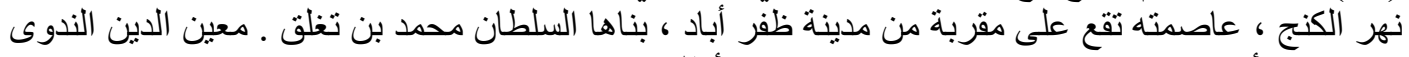

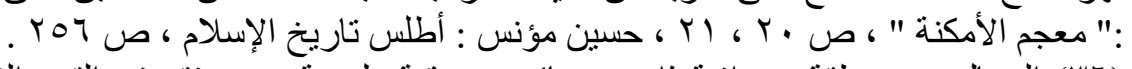

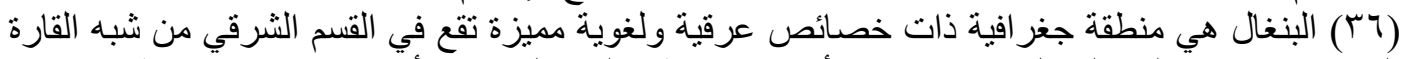

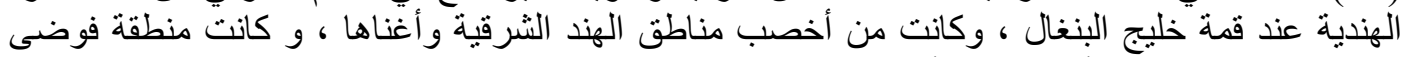

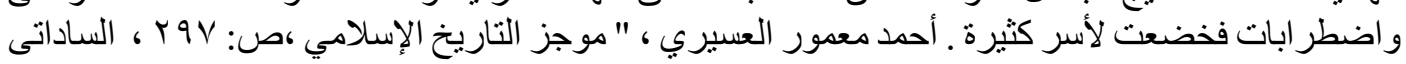

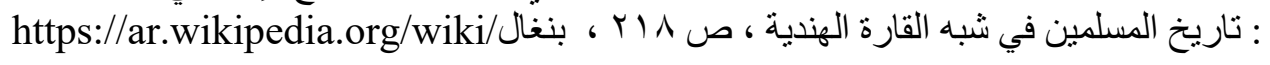




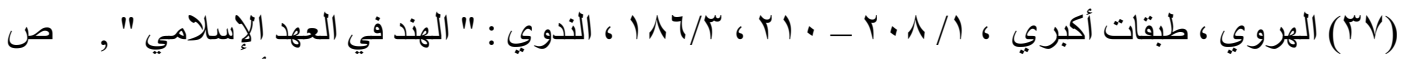

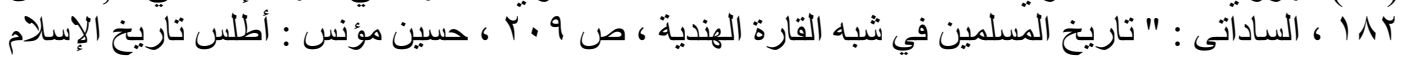

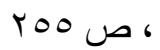

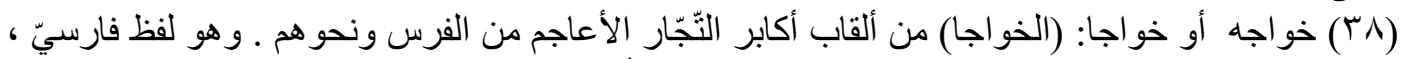

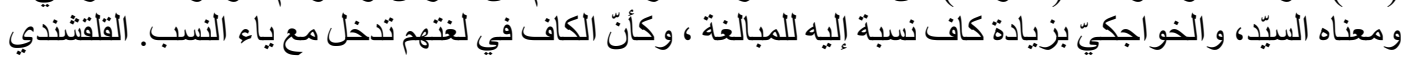

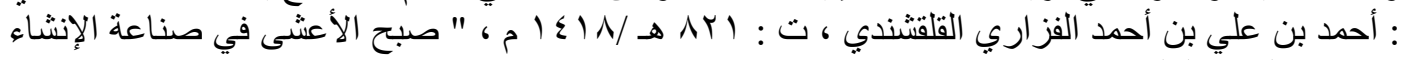

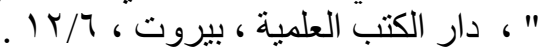

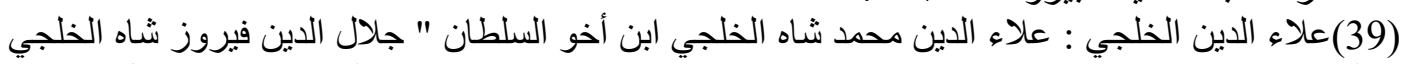

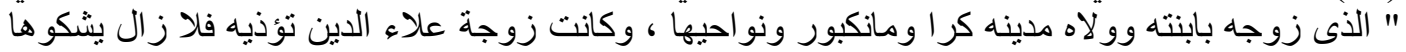

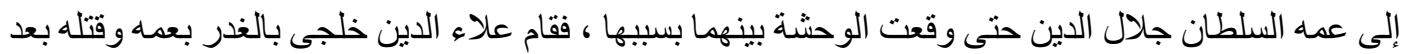

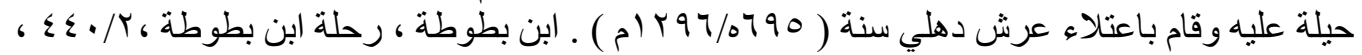

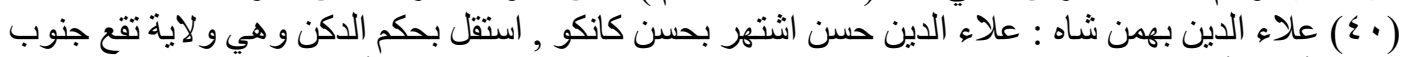

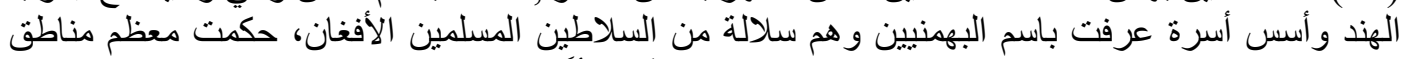

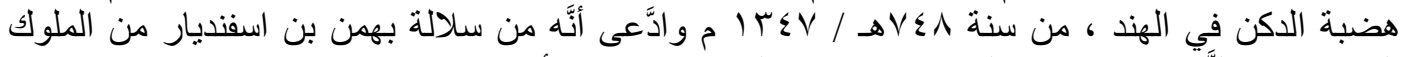

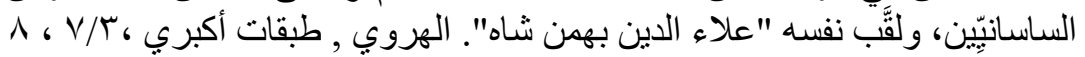

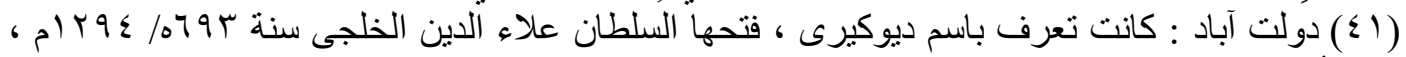

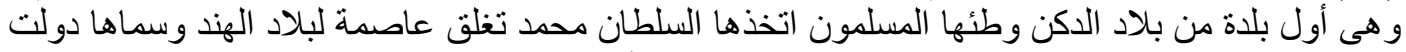

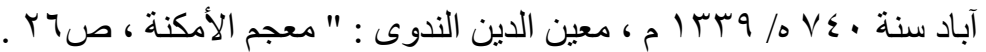

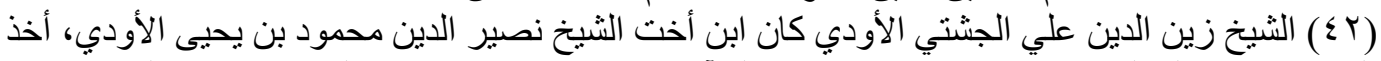

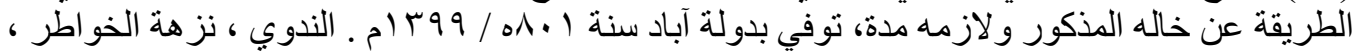
rol $/ \mathrm{r}$

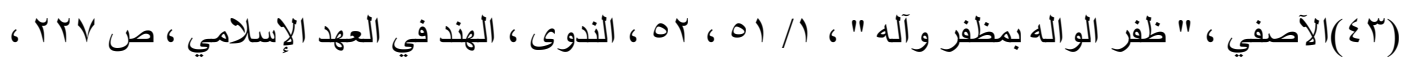
- Briggs, John, History of The rise of the Mahomedan Power in India, vol Iv, p 281 (44)Briggs, John, History of The rise of the Mahomedan Power in India, vol Iv, p 281

(45)Briggs, John, History of The rise of the Mahomedan Power in India ,vol Iv, p 282

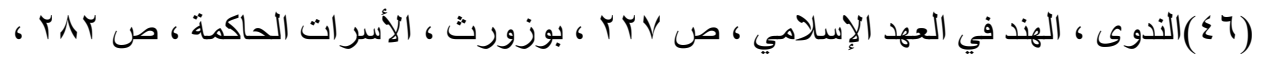
- Briggs, John, History of The rise of the Mahomedan Power in India , vol Iv, P 282

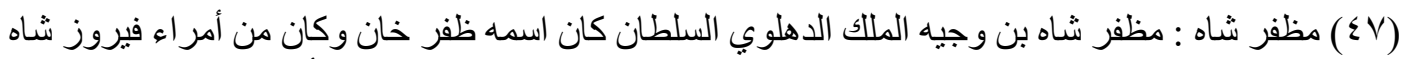

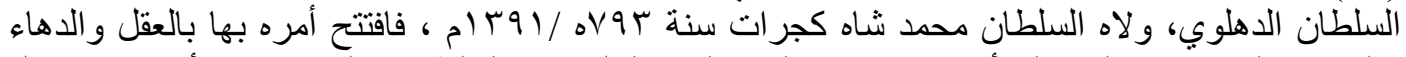

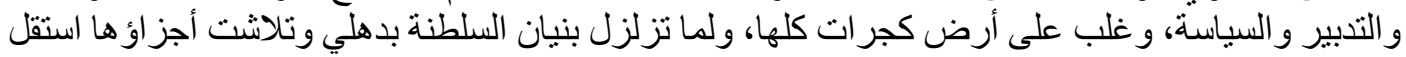

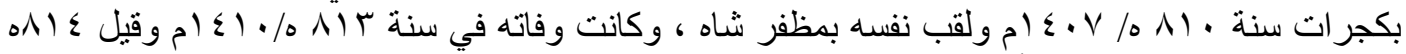

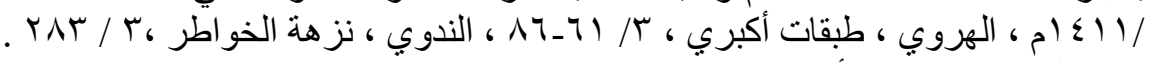

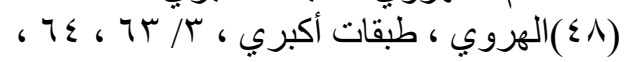

- Briggs, John, History of The rise of the Mahomedan Power in India, vol Iv, p 283 ، or / ، الآصفي : ظقفر الواله (9)

Briggs, John, History of The rise of the Mahomedan Power in India, vol Iv, p 283 (50)J. ALLAN, M.A. The Cambridge shorter History of India , CAMBRIDGE, AT THE UNIVERSITY PRESS,1934. p 300

(51)Briggs, John, History of The rise of the Mahomedan Power in India, vol Iv, p 285

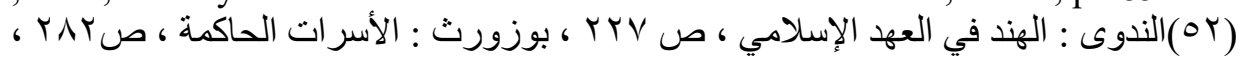


- Briggs, John, History of The rise of the Mahomedan Power in India, vol Iv, p 286

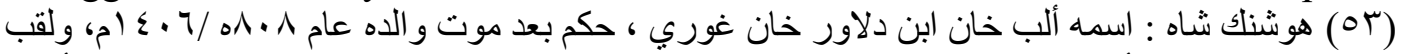

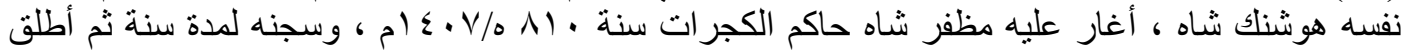

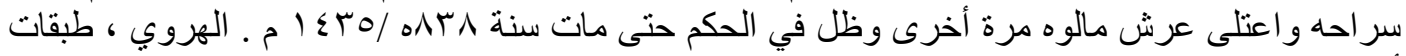

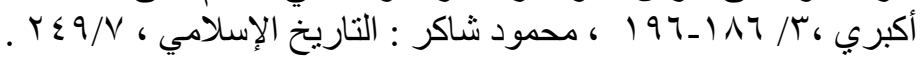

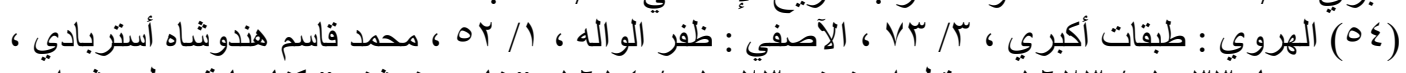

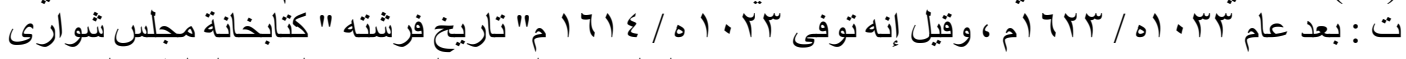

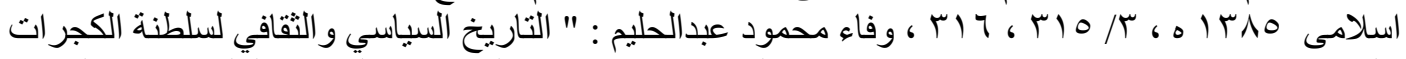

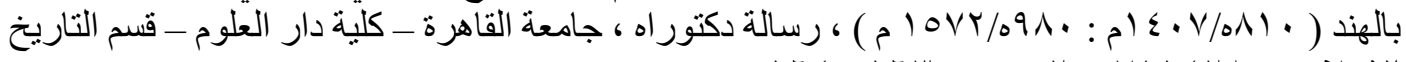

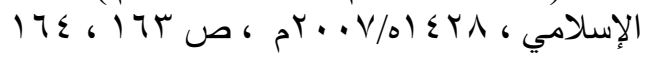
-HAIG, WOLSELEY: THE CAMBRIDGE HISTORY OF INDIA VOL III "Turks and Afghans" CAMBRIDGE, AT THE UNIVERSITY PRESS, 1928 . p 297

- J. ALLAN, M.A. The Cambridge shorter History of India , p 300

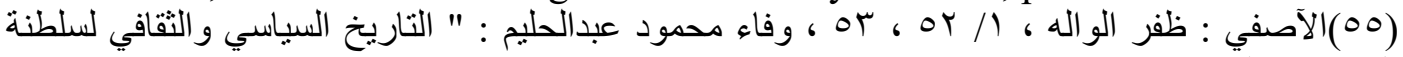

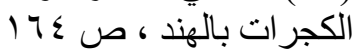
(56)HAIG, WOLSELEY: THE CAMBRIDGE HISTORY OF INDIA VOL III , p 297

(57)Briggs, John, History of The rise of the Mahomedan Power in India, vol Iv, p 293

-HAIG, WOLSELEY: THE CAMBRIDGE HISTORY OF INDIA VOL III , p 297 (01) جهالاو ار : مقاطعة صغيرة بين الكجرات وماتلوه (29) -S.C. Misra : The Rise of Muslim power in Gujarat, A History of Gujarat from 1298 to 1442 , Asia publishing House New York. p 173

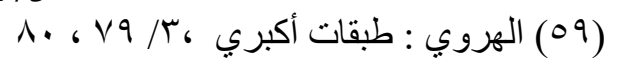

- Briggs, John, History of The rise of the Mahomedan Power in India , vol Iv, p 293,294

-HAIG, WOLSELEY: THE CAMBRIDGE HISTORY OF INDIA VOL III , p 298 ,299

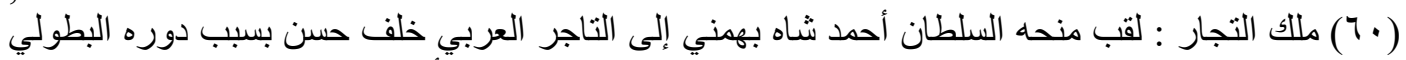

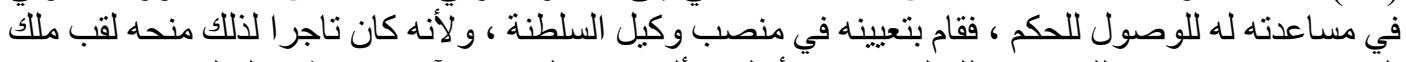

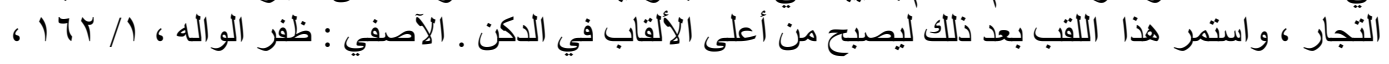
HAROON Khan SHERWANI: THE PAHMANIS OF THE DECCAN , International. Printers, Hyderabad - Deccan- India, ,p 191

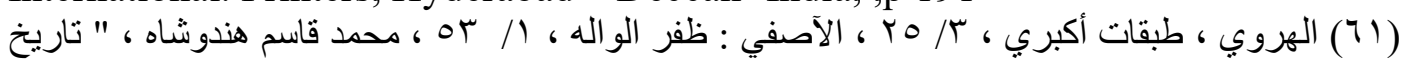

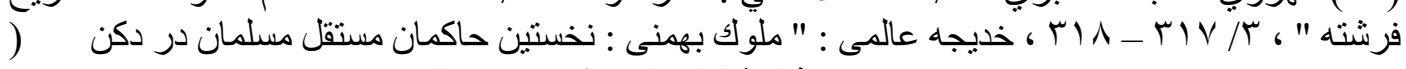

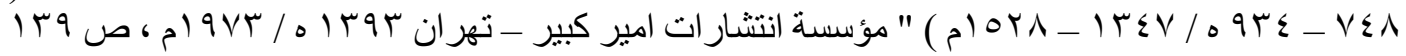

- HAROON Khan SHERWANI: THE PAHMANIS OF THE DECCAN , International. Printers, Hyderabad - Deccan- India, p 233,235 .

- HAIG, WOLSELEY: THE CAMBRIDGE HISTORY OF INDIA VOL III , p 300

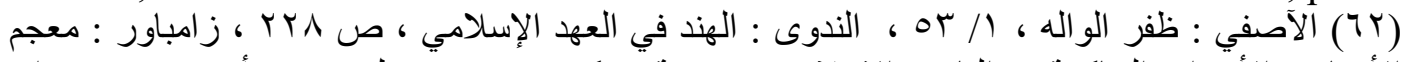

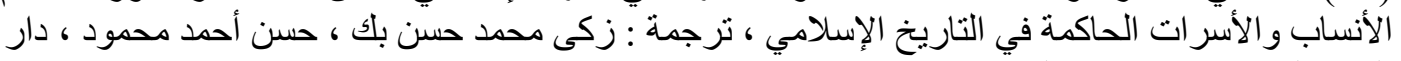

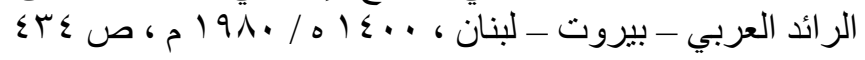


-History of The rise of the Mahomedan Power in India , vol Iv, p 296 HAROON Khan SHERWANI: THE PAHMANIS OF THE DECCAN ,p 236

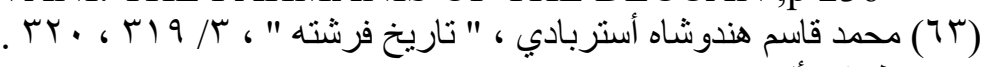

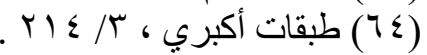

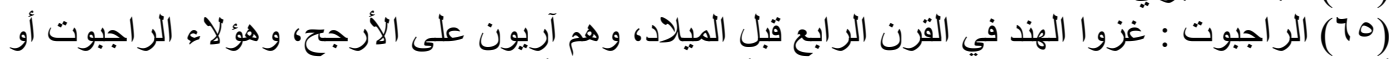

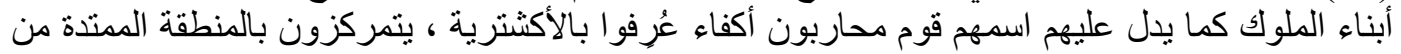

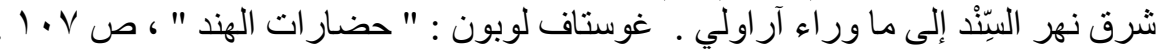

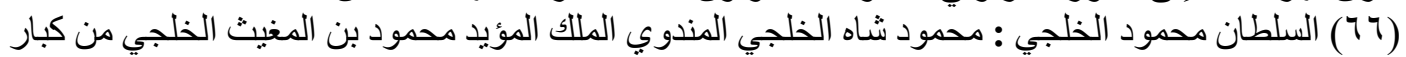

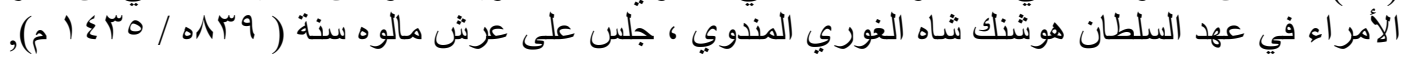

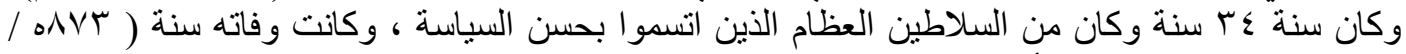

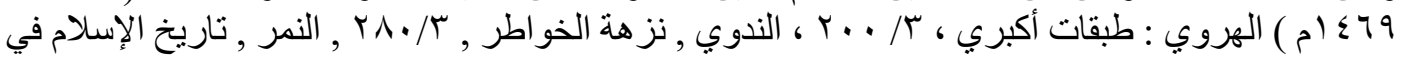

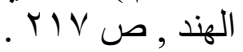

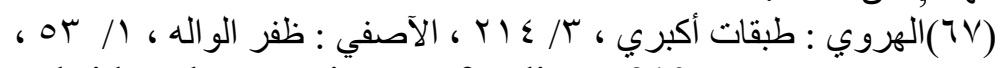
J. ALLAN, M.A. The Cambridge shorter History of India , p 310

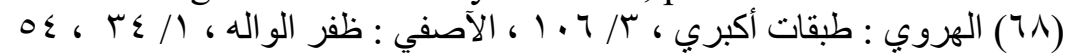

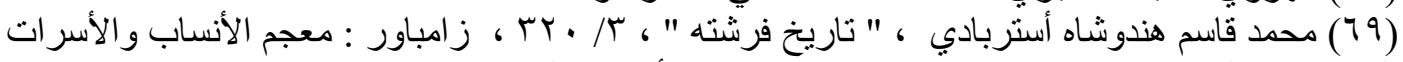

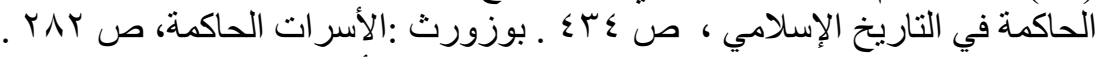

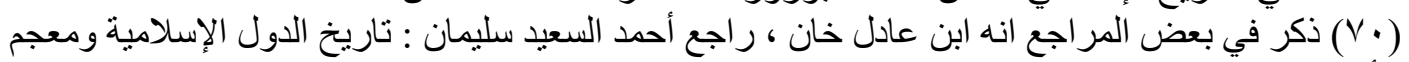

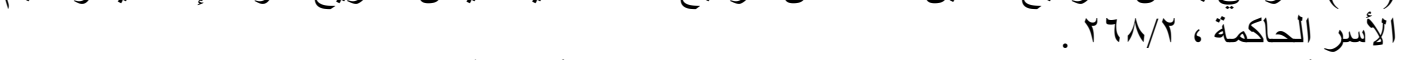

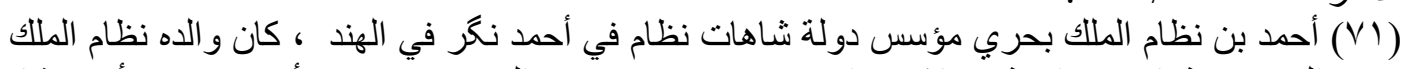

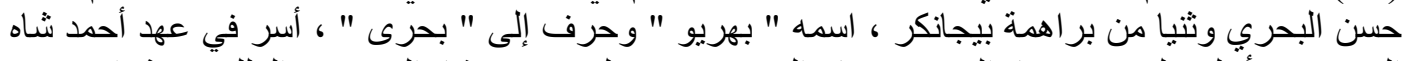

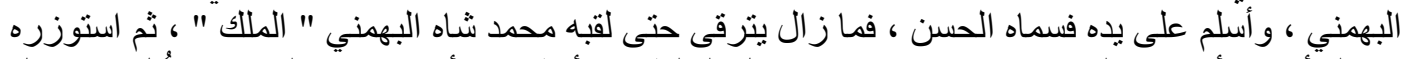

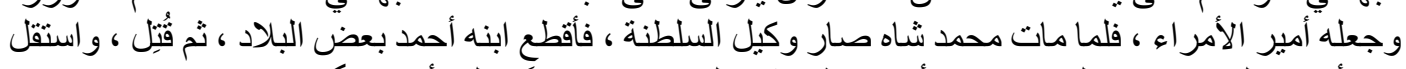

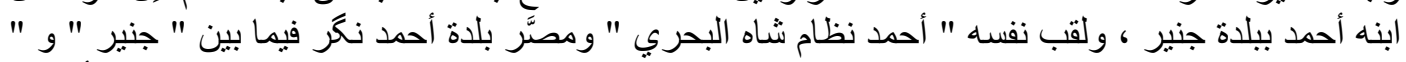

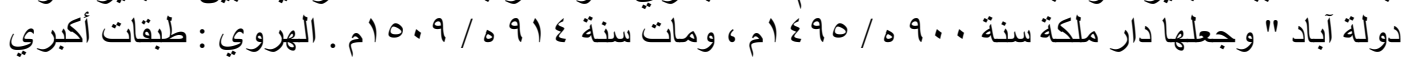

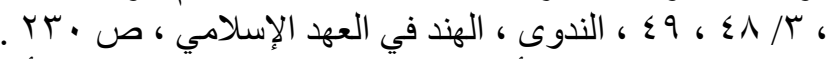

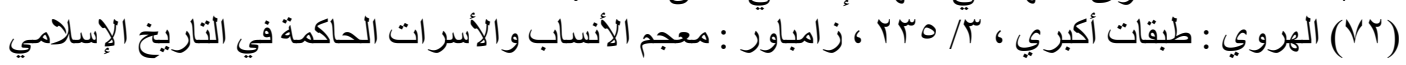

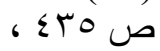
HAIG, WOLSELEY: THE CAMBRIDGE HISTORY OF INDIA VOL III , p 313 .

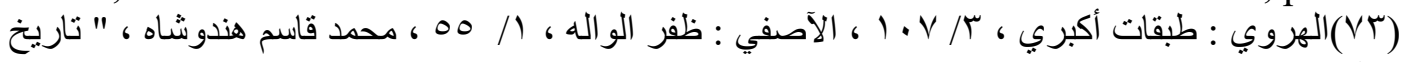

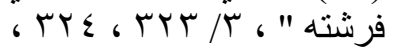
-HAIG, WOLSELEY: THE CAMBRIDGE HISTORY OF INDIA VOL III , p 313

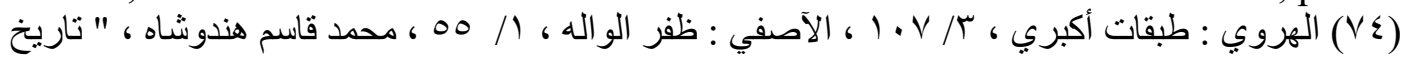

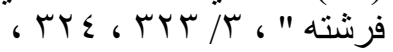
-HAIG,WOLSELEY: THE CAMBRIDGE HISTORY OF INDIA VOL III, $p$ 313,314

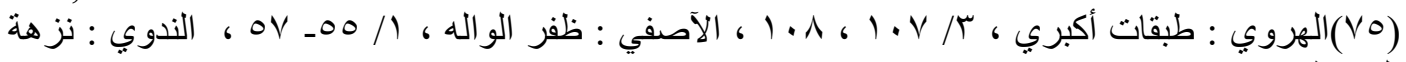

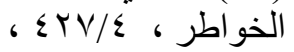

- Briggs, John, History of The rise of the Mahomedan Power in India, vol Iv, p 303,304

(76)HAIG, WOLSELEY: THE CAMBRIDGE HISTORY OF INDIA VOL III , p 314

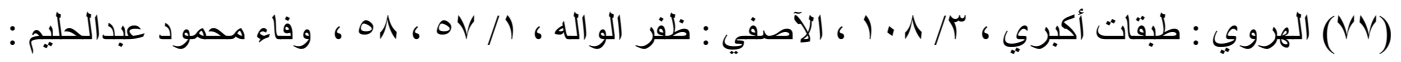




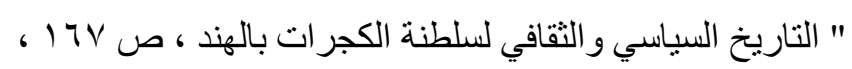
Briggs, John, History of The rise of the Mahomedan Power in India , vol Iv, p 305,306

(VA)

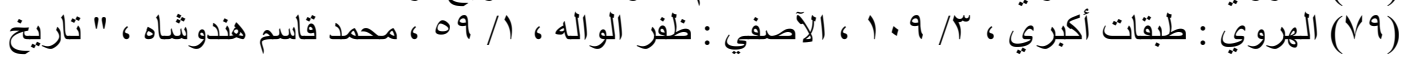

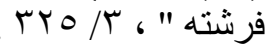

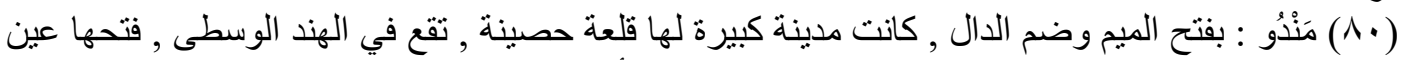

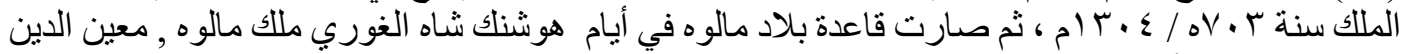

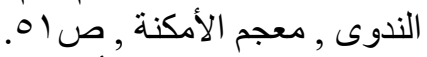

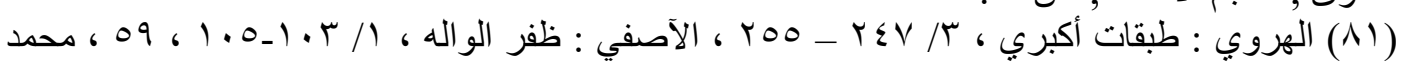

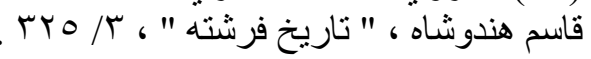

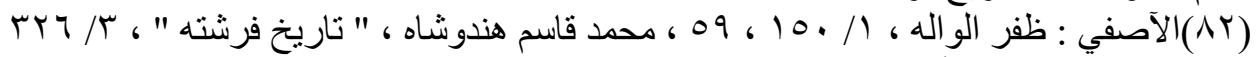

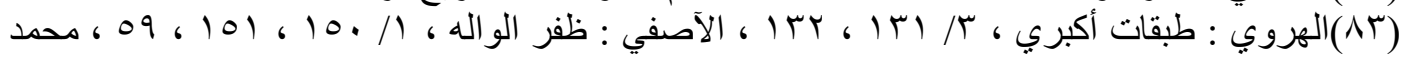

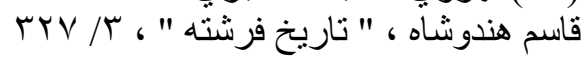

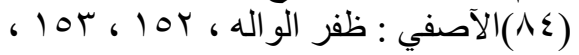
- Briggs, John, History of The rise of the Mahomedan Power in India , vol Iv, p 309,310

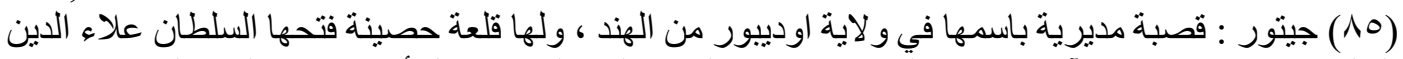

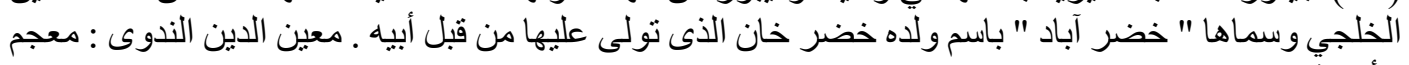

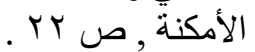

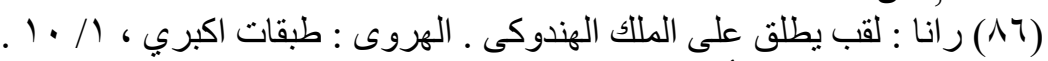

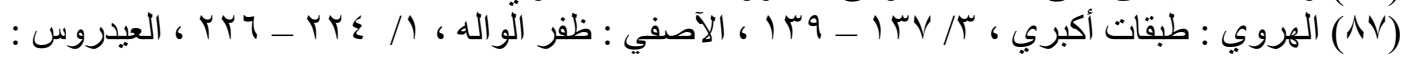

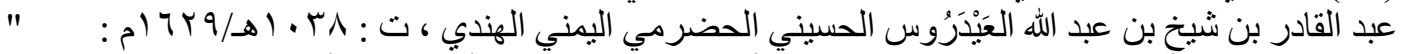

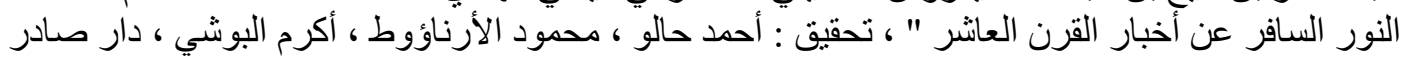

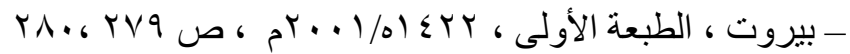

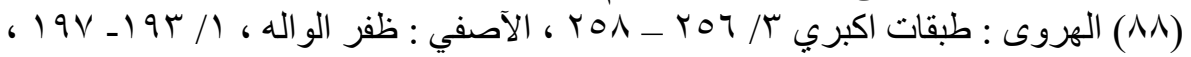
Briggs, John, History of The rise of the Mahomedan Power in India , vol Iv, p 310, 311

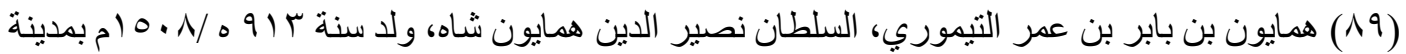

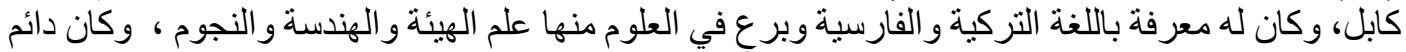

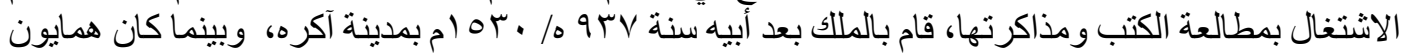

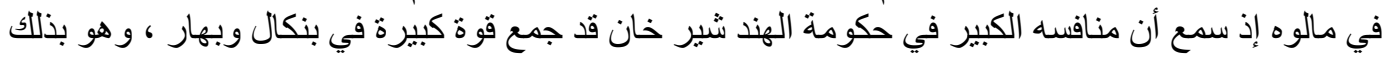

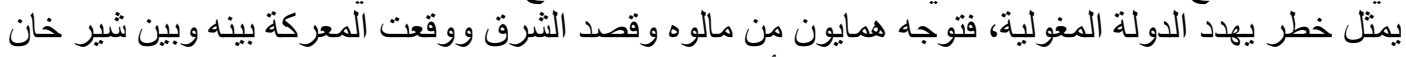

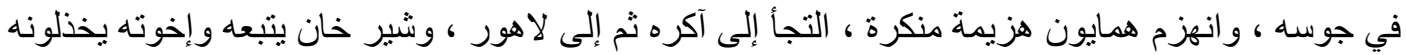

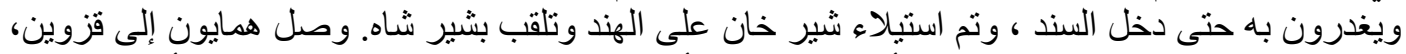

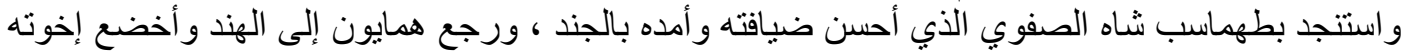

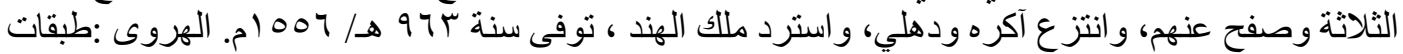

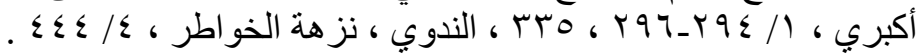

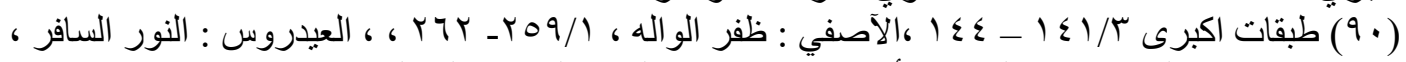

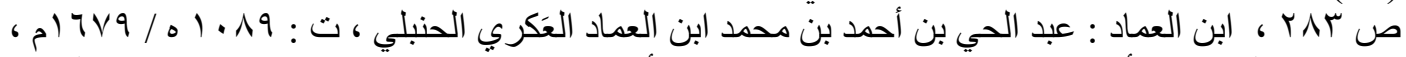

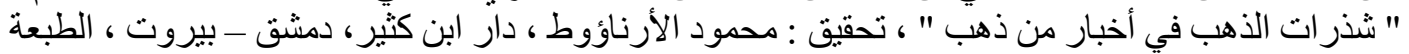

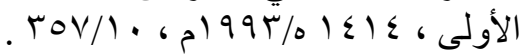

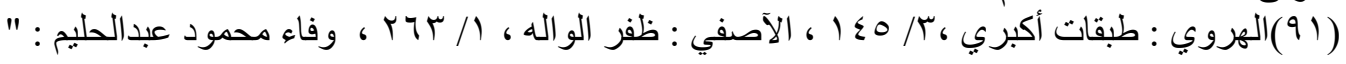




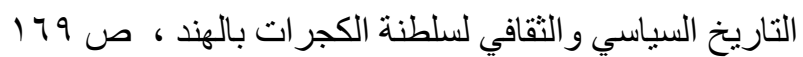

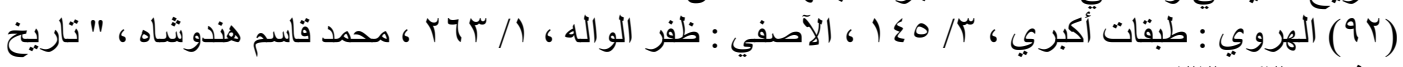

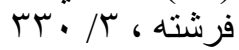

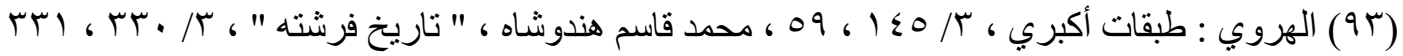

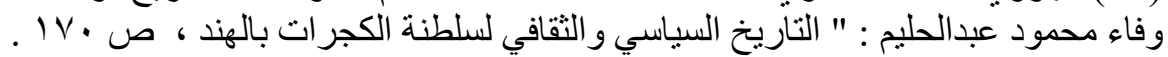
EDWARD CLIVE BAYLEY, THE LOCAL MUHAMMADAN DYNASTIES. GUJARAT, LONDON:1886,p 303,304 .

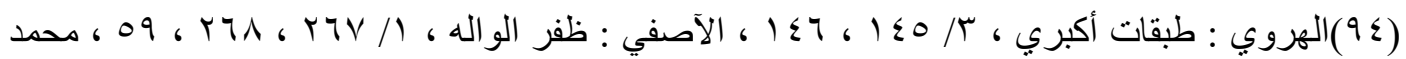

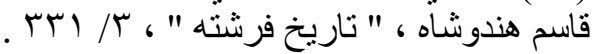

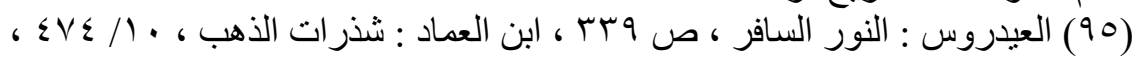
GAZETTEER OF THE BOMBAY PRESIDENCY VOL.1,PART.1 History of GUJARAT , Government Central Press (Bombay) 1896 ,p 259

(96) GAZETTEER OF THE BOMBAY PRESIDENCY VOL.1,PART.1 History of GUJARAT p 260,261

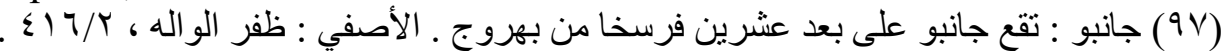

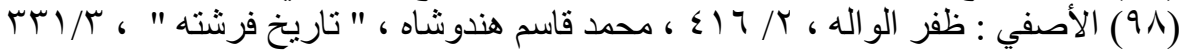
-GAZETTEER OF THE BOMBAY PRESIDENCY VOL.1,PART.1 History of GUJARAT $\mathrm{p} 261$.

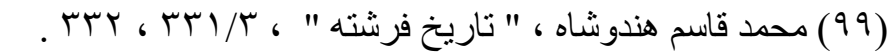

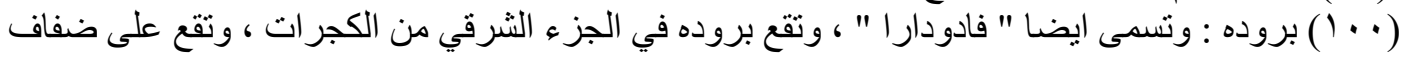

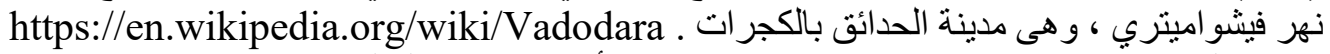

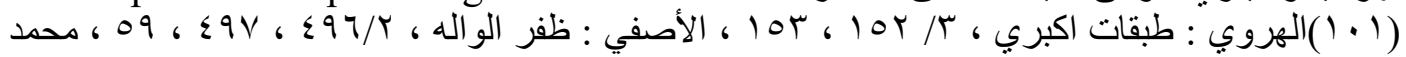

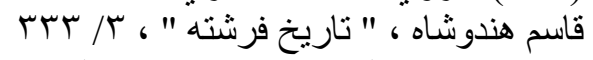

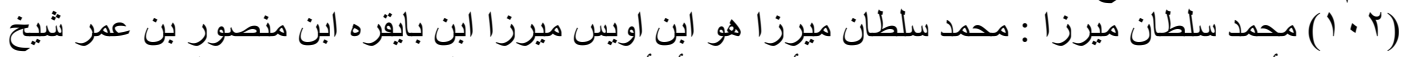

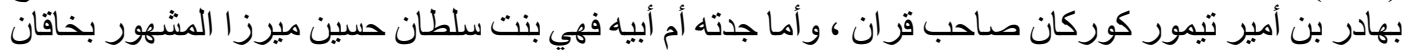

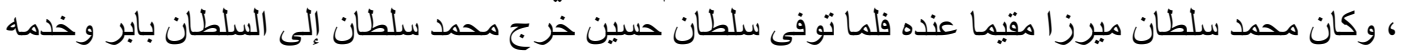

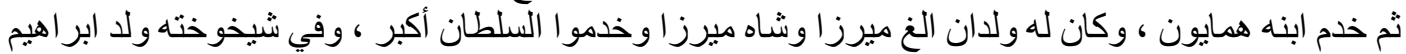

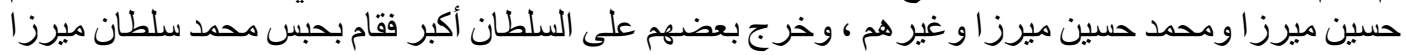

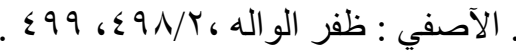

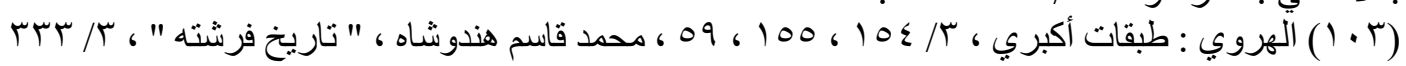
(1)

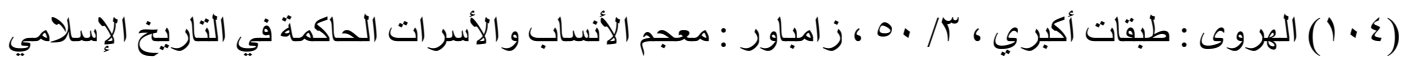

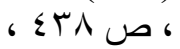

Briggs, John, History of The rise of the Mahomedan Power in India, vol Iv, p319,320 - HAIG,WOLSELEY: THE CAMBRIDGE HISTORY OF INDIA VOL III, p 454 ,455

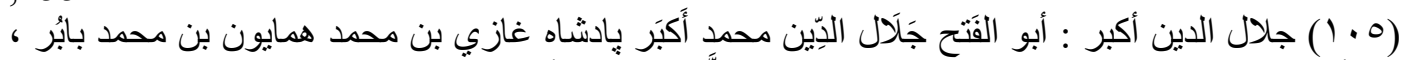

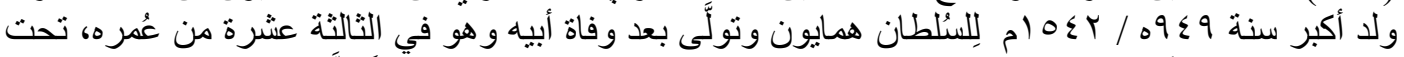

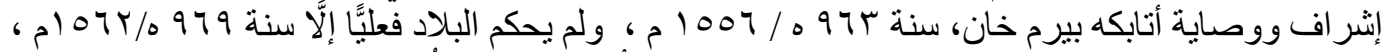

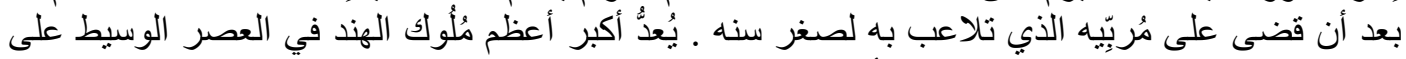

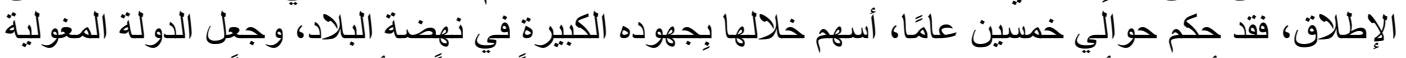

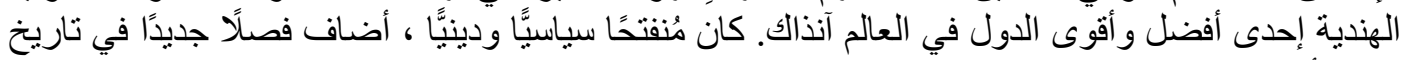

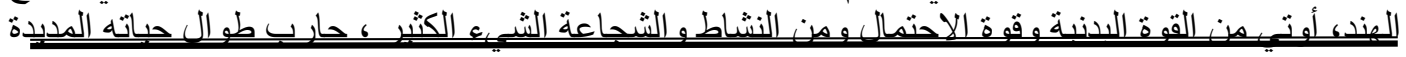


من أقصى الهند إلى أقصاها، فغز ا الكجرات وسورت وأفغان البنغال وسلطنة أحمد نكر وغير ها ، كما ردَّا

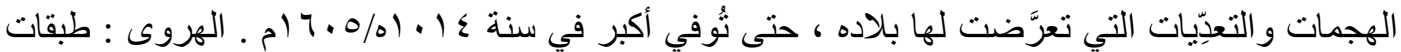

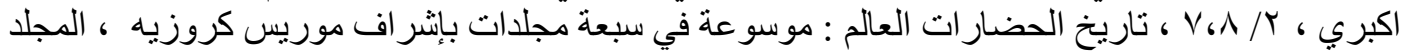

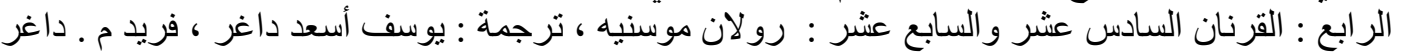

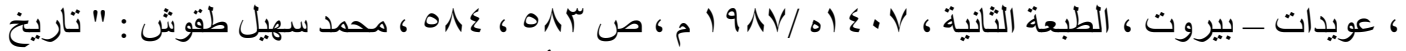

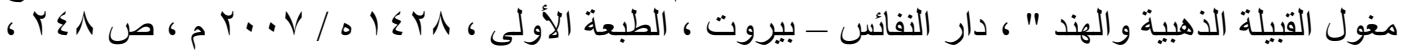

. $r \leqslant 9$

(106)Briggs, John, History of The rise of the Mahomedan Power in India, vol Iv , p 321

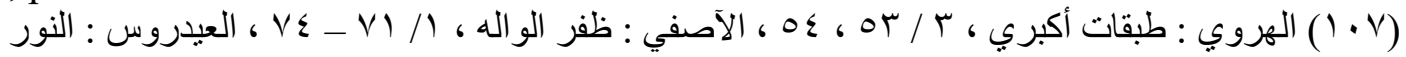

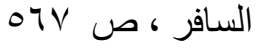

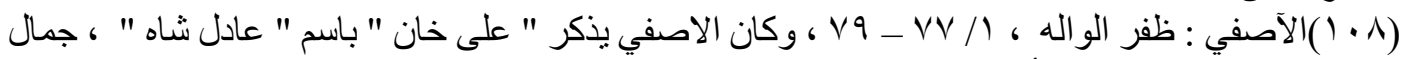

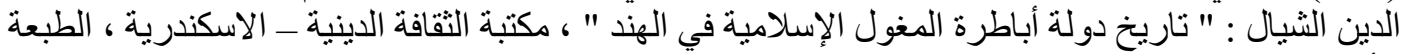

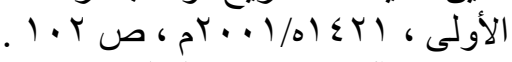

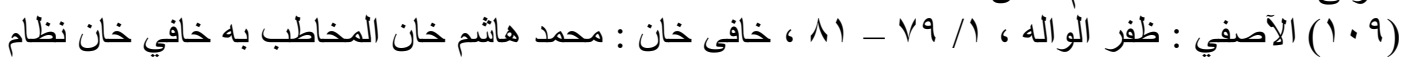

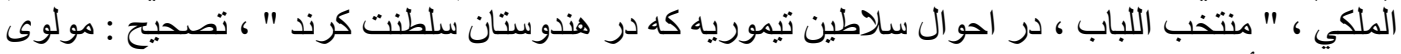

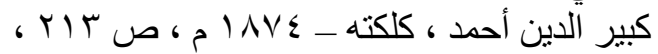
Briggs, John, History of The rise of the Mahomedan Power in India , vol Iv, p 325

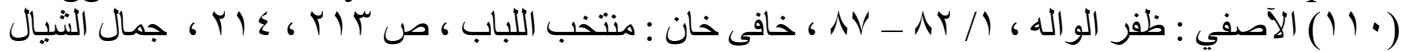

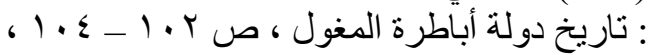
Briggs, John, History of The rise of the Mahomedan Power in India , vol Iv, p 325 - 327

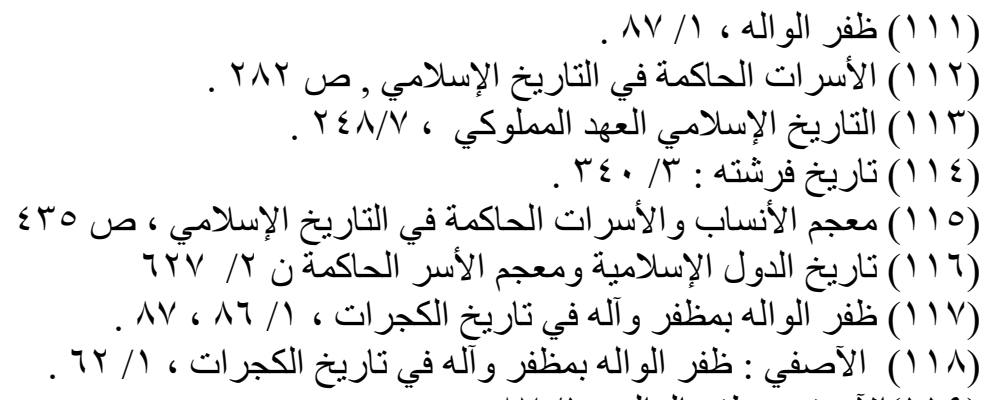

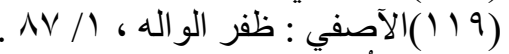

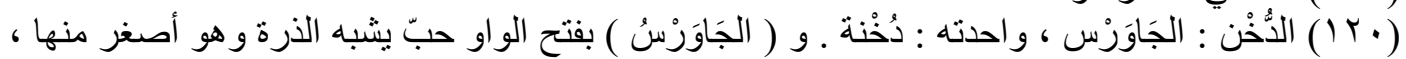

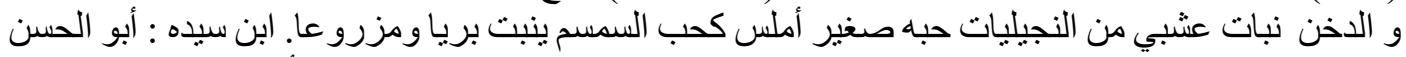

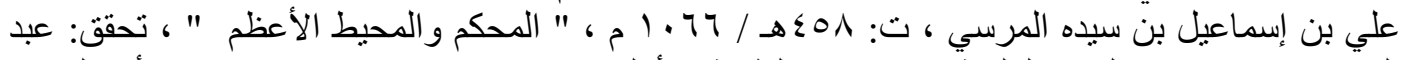

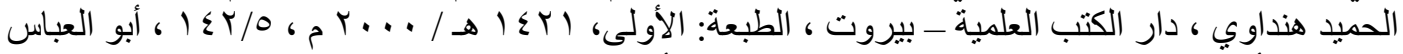

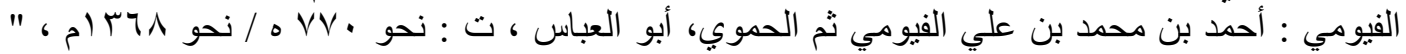

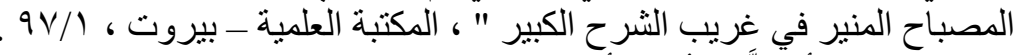

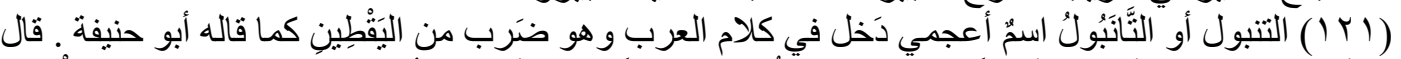

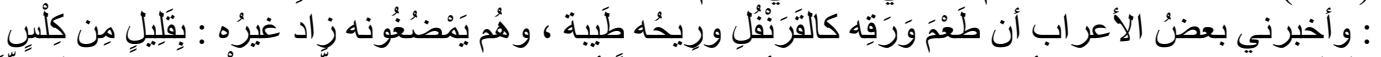

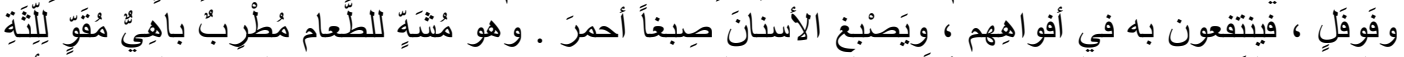

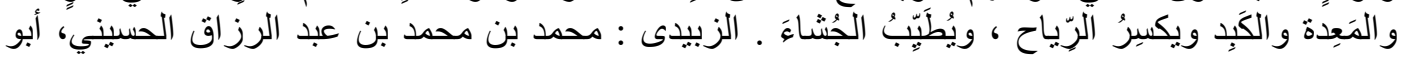

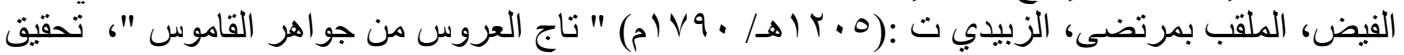

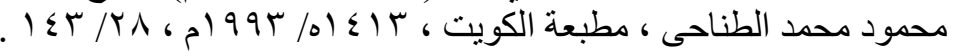


(122) Abu'l Fazl, Ain-i-Akbari, Translated from PERSIAN by : H- S. JARRETT, Calcutta, 1949, vol. II, P. 232-33,

-GAZETTEER OF THE BOMBAY PRESIDENCY VOI XII .KHANDESH PRINTED AT THE GOVERNMENT CENTRAL PRESS, Bombay, 1880 ,p 247,248

(123) Abu'l Fazl, Ain-i-Akbari, vol. II, P. 232, GAZETTEER OF THE BOMBAY PRESIDENCY VOL XII, KHANDESH, $\mathrm{p} 248$

(124) GAZETTEER OF THE BOMBAY PRESIDENCY VOLUME XII, KHANDESH, 226,248

(125) GAZETTEER OF THE BOMBAY PRESIDENCY VOLUME XII, KHANDESH,p 248

-THE IMPERIAL GAZETTEER OF INDIA, VOL. XV, p 226

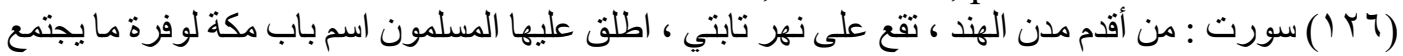

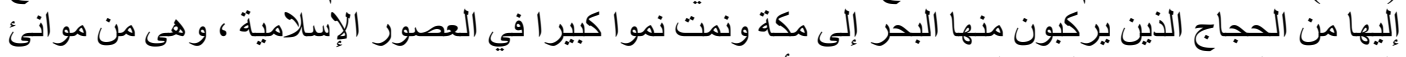

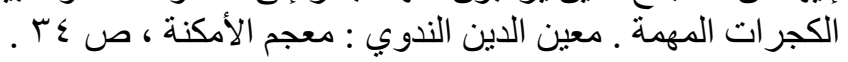
(127)GAZETTEER OF THE BOMBAY PRESIDENCY VOLUME XII 207,248 ,249

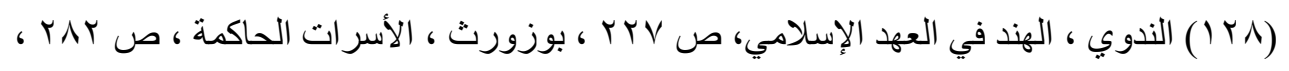

- Briggs, John, History of The rise of the Mahomedan Power in India , vol Iv, p 286 -Law , Narendra Nath, Promotion of Learning in India during Muhammadan Rule, new delhi , 1916, p 98,99.

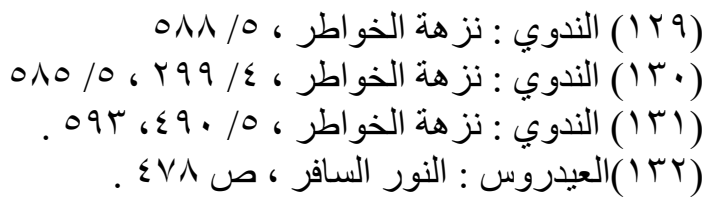

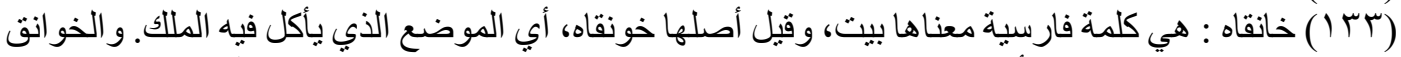

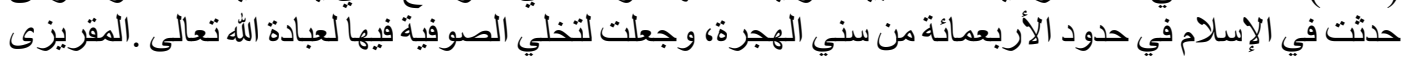

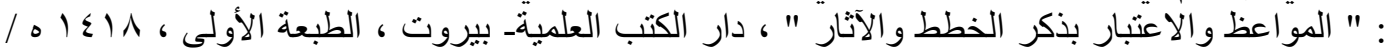

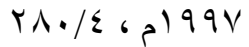

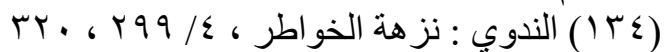

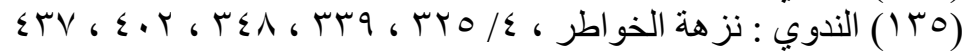

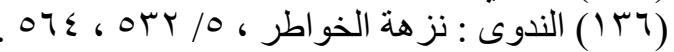

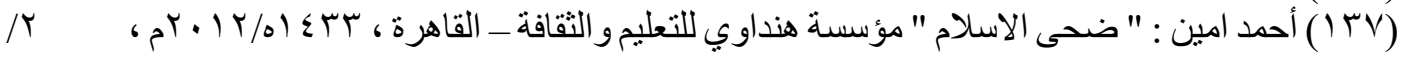

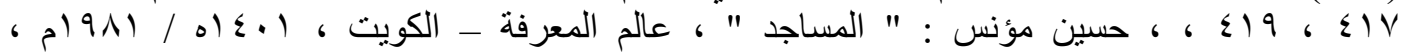
ص •

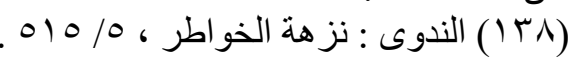

(139) BROWN, PERCY: INDIAN ARCHITECTURE (The Islamic Period) TARAPOREVALA'S TREASURE HOUSE OF BOOKS- BOMBAY $\mathrm{p} 83$ -ALEXANDER CUNNINGHAM : ARCHÆOLOGICAL SURVEY OF INDIA. REPORT OF A TOUR IN THE CENTRAL PROVINCES, 1873-74 \& 1874-75, CALCUTTA : OFFICE OF THE SUPERINTENDENT OF GOVERNMENT PRINTING . 1879, VOL IX, p 115

(140) BROWN PERCY. INDLANARCHITECTURE(The Islamic Period) 83 
-ALEXANDER CUNNINGHAM: ARCHÆOLOGICAL SURVEY OF INDIA, $p$ 117

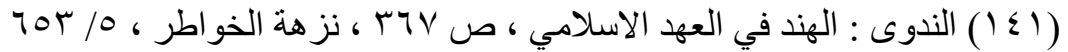

$$
\begin{aligned}
& \text { T/ }
\end{aligned}
$$

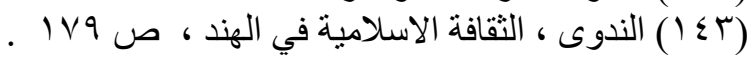

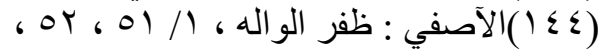

Briggs, John, History of The rise of the Mahomedan Power in India , vol Iv, p 281

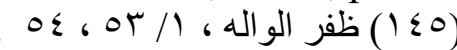

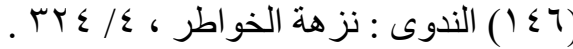

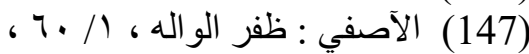

-Abu'l Fazl, Ain-i-Akbari , vol. II, P.191- 193

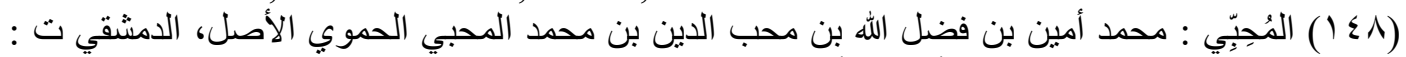

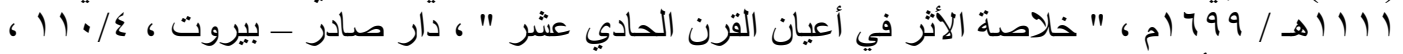

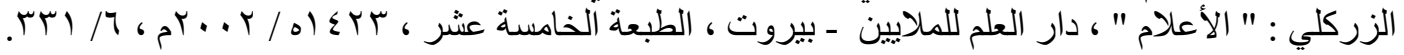

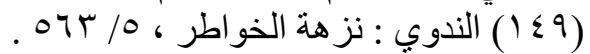

(150) THE IMPERIAL GAZETTEER OF INDIA VOL ,Ix, BOMJUR TO CENTRAL INDIA, p105

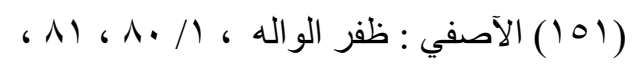

-BROWN, PERCY: INDIAN ARCHITECTURE (The Islamic Period) p 83

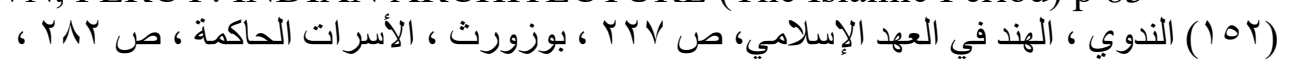

- Briggs, John, History of The rise of the Mahomedan Power in India , vol Iv, p 286 -SPOONER, D. BRAINERD : Annual Report Of The Archaeological Survey Of India 1922 -1923, universal library, $\mathrm{p}$ 47,48

(153) BROWN, PERCY: INDIAN ARCHITECTURE (The Islamic Period) p 83 -ALEXANDER CUNNINGHAM : ARCHÆOLOGICAL SURVEY OF INDIA. $p$ 115

(154) BROWN, PERCY: INDIAN ARCHITECTURE (The Islamic Period)p 83 -ALEXANDER CUNNINGHAM : ARCHAEOLOGICAL SURVEY OF INDIA p117

(155) SPOONER , D. BRAINERD: Annual Report Of The Archaeological Survey Of India 1922- 1923, p 46

(156) ALEXANDER CUNNINGHAM : ARCHÆOLOGICAL SURVEY OF INDIA. p118

(157) BROWN, PERCY: INDIAN ARCHITECTURE (The Islamic Period) p 83 


\section{قائمة المصادر والمراجع}

• أـ الصصفي : المبر العربية

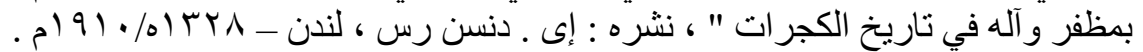

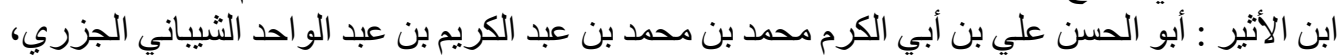

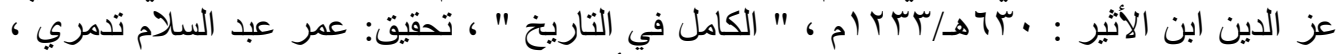

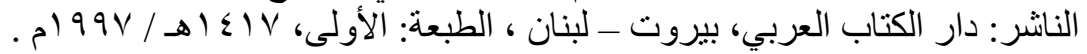

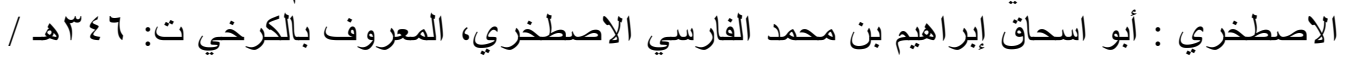

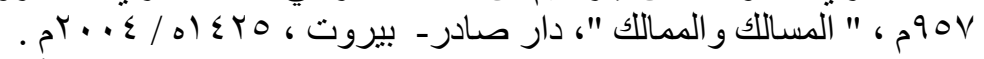

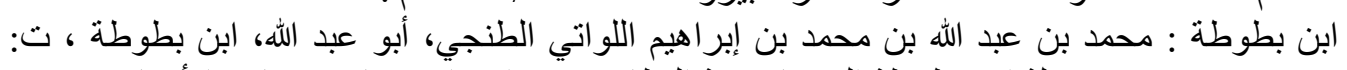
هـ هـVV

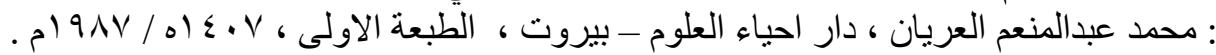

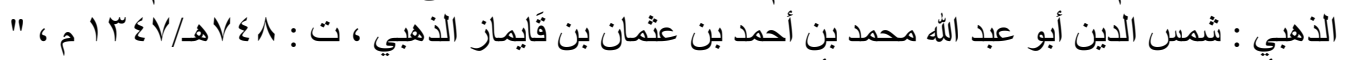

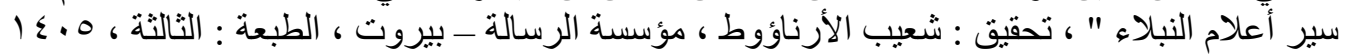

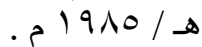

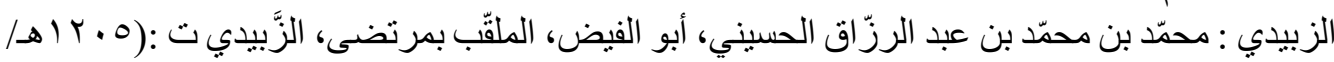

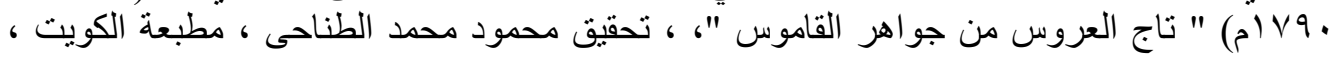

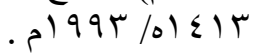

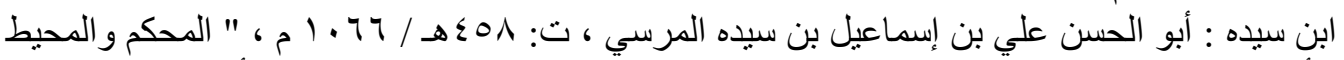

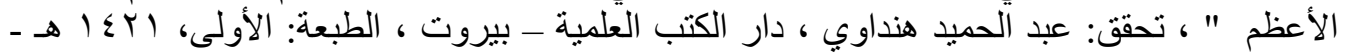
أبو

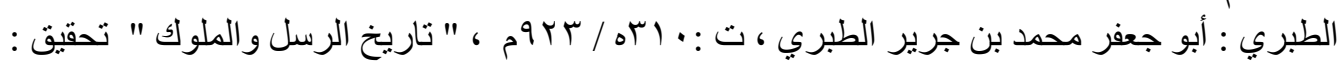

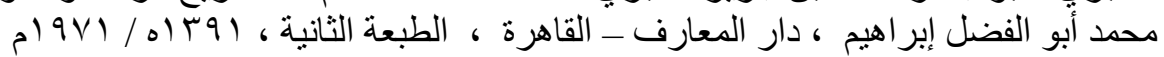

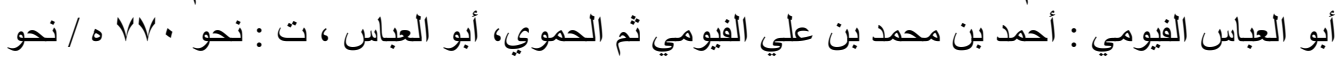

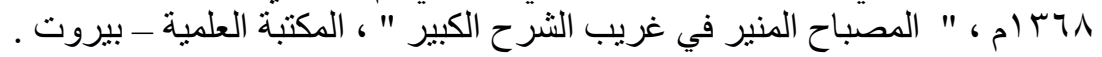

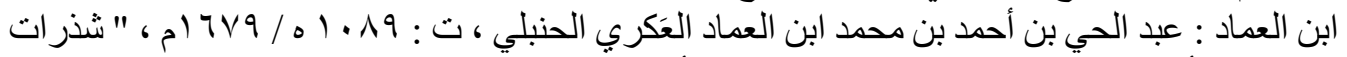

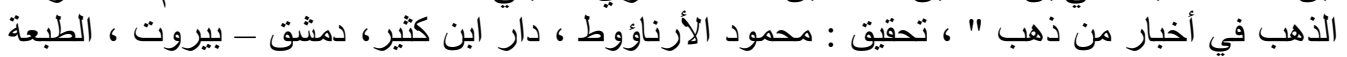

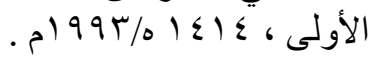

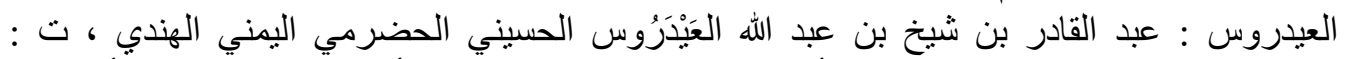

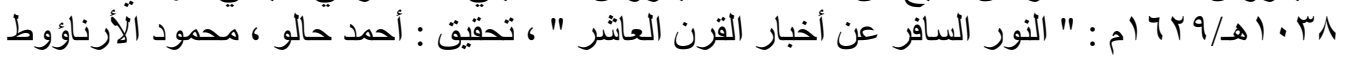

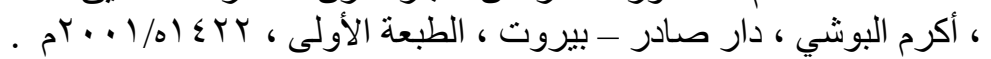

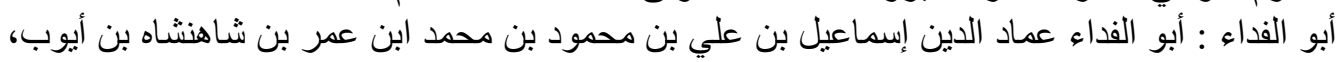

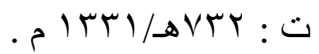
- - " المختصر في أخبار البشر " ، المطبعة الحسينية المصرية ـ مصر ، الطبعة: الأولى .

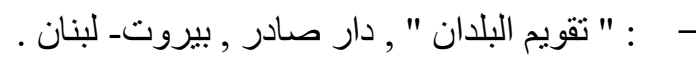

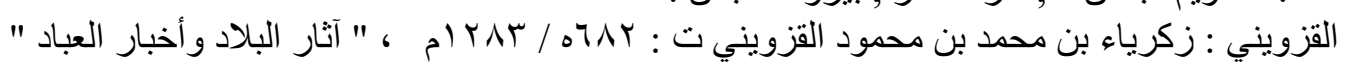

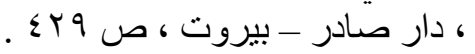

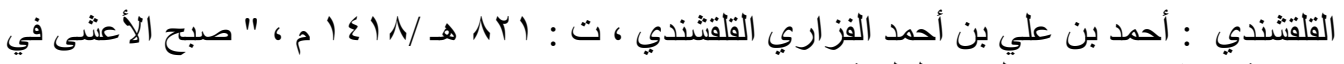

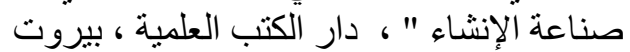

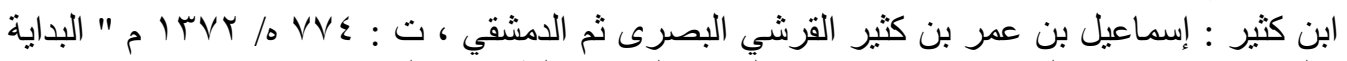

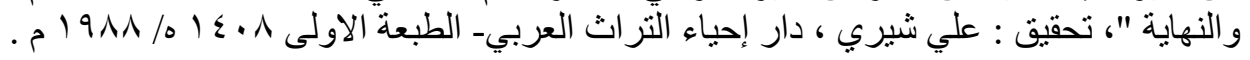




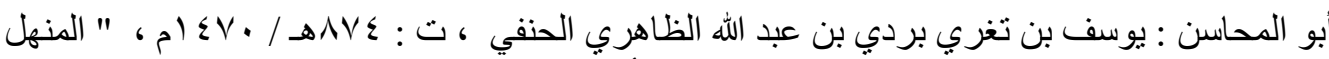

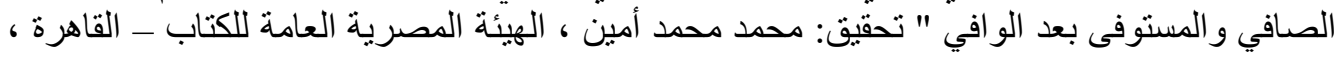
. $917 / 018.7$

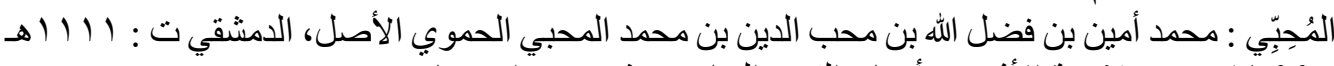

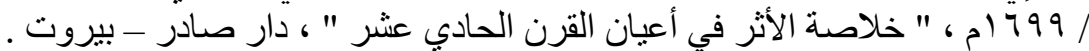

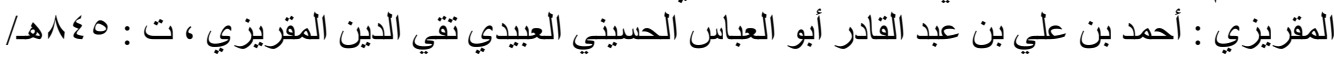
. م $1 \leq \varepsilon 1$ ـ " السلوك لمعرفة دول الملوك اكو " ، تحقيق: محمد عبد القادر عطا ، دار الكتب العلمية ـ بيروت ، الطبعة:

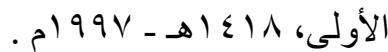

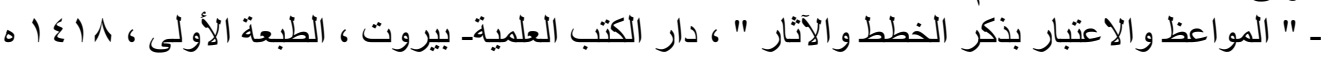
. م) $99 \mathrm{~V} /$

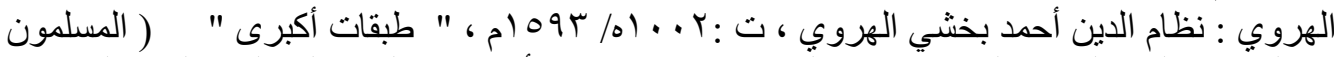



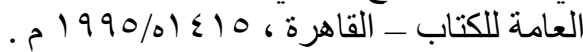

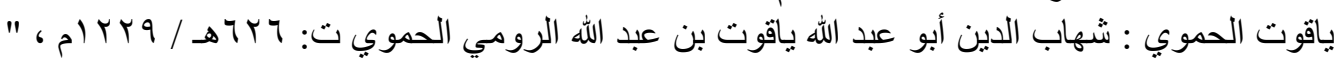

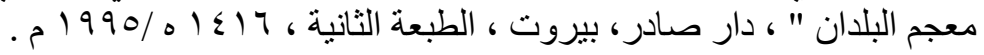

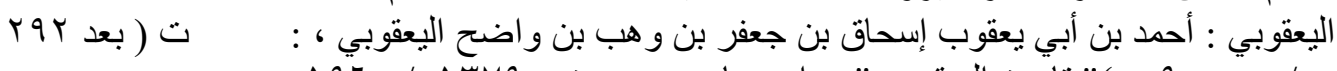

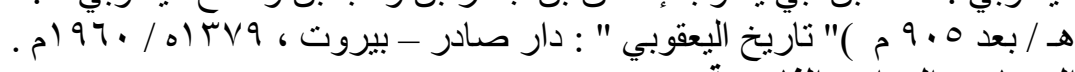
ب ـ المصادر والمراجع الفارسبية

خافى خان : محمد هاثم خان المخاطب به خافي خان نظام الملكي ، " منتخب اللباب ، در در احوال

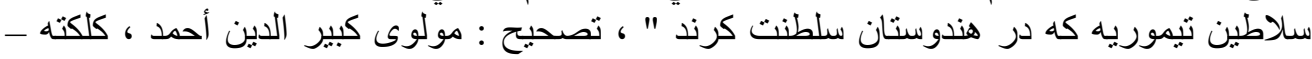

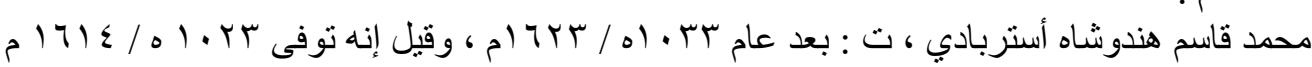

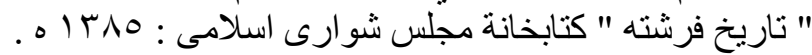

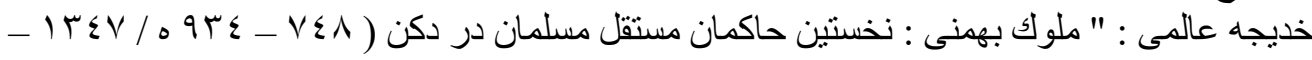

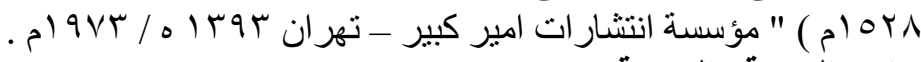

\section{ج - المراجع العربية وانية والمعربية}

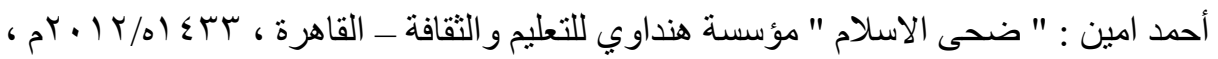

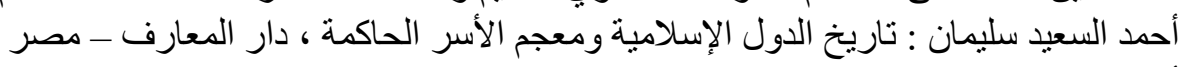

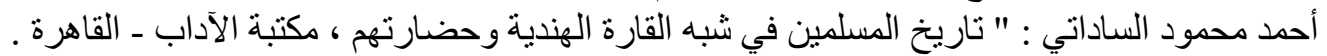

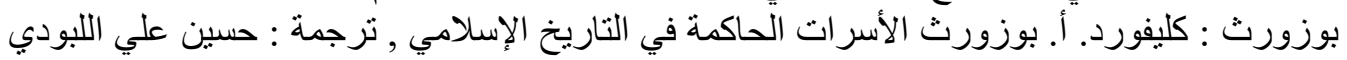

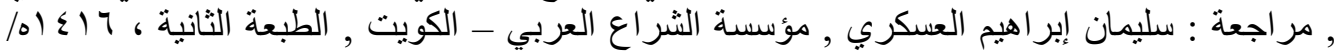
. م) 990 جمال الدين الثيال : " تاريخ دولة أباطرة المغول الإسلامية في الهند " ، مكتبة الثقافة الدينية ـ الاسكندرية

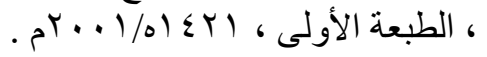

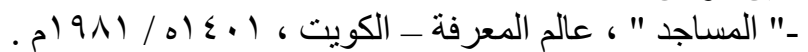
حسين مؤنس :

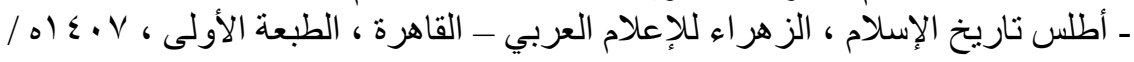




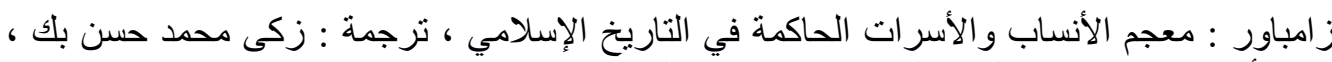

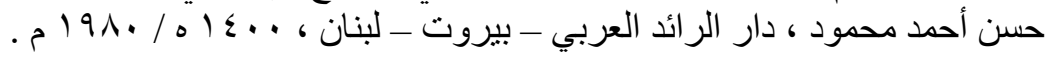

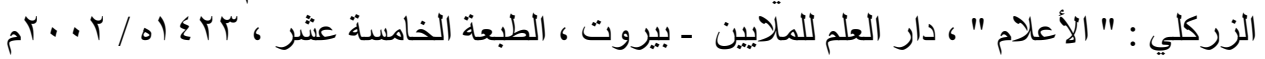

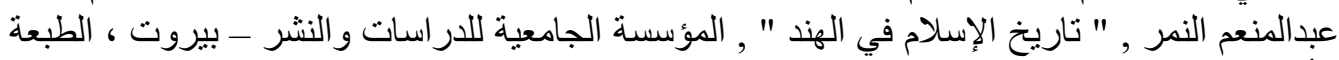

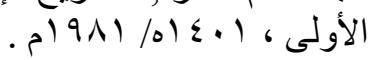

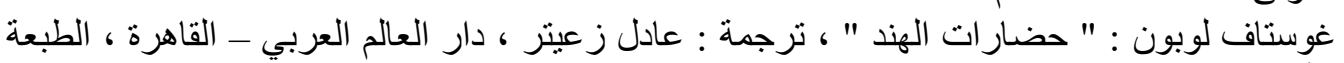

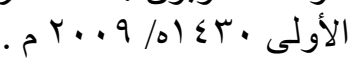

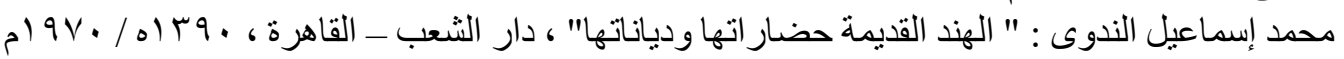
محمد سهيل طقوش : " تاريخ مغول القبيلة الذهبية والهند " ، دار النفائس - بيروت ، الطبعة الأولى ،

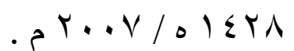

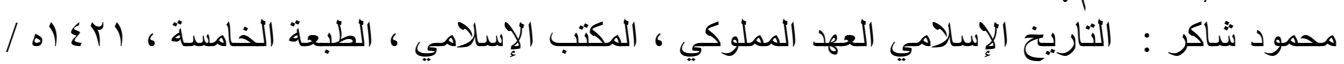

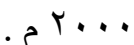

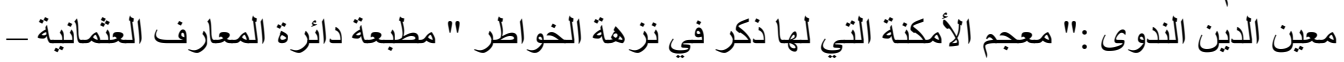

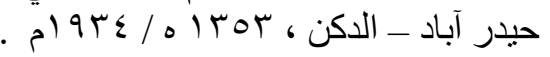

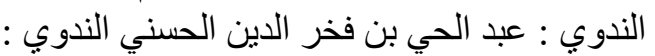

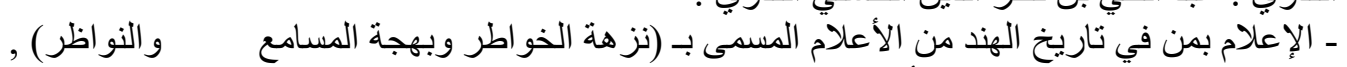

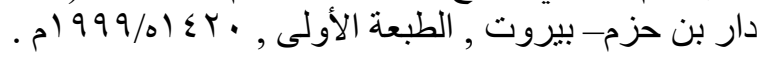
ـ " الهند في العهد الإسلامي " , راجعه وقدمه : أبو الحسن علي الحسني الندوي , دار عرفات

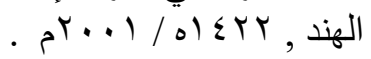

\section{لــ الموسوعات و الرسائل العلمية}

تاريخ الحضار ات العالم : موسو عة في سبعة مجلدات بإنشر اف موريس كروزيه ، المجلد الرابع : القرنان

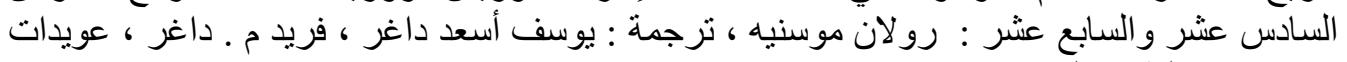

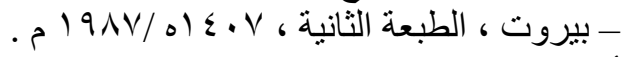

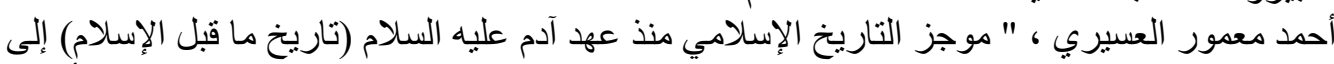

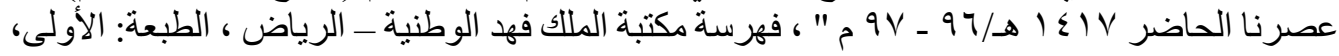

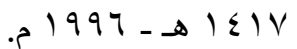

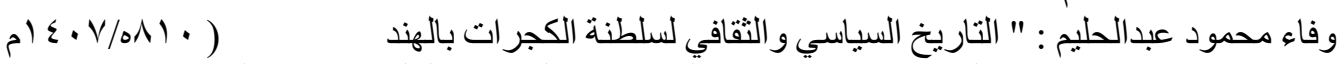

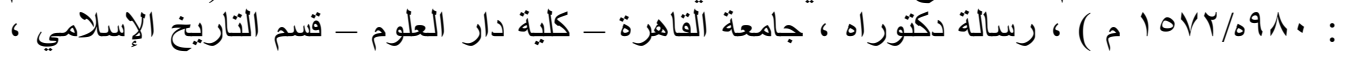

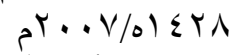
0 - المراجع الأجنيية

-Abu'l Fazl, Ain-i-Akbari, Translated from PERSIAN by : H- S. JARRETT, Calcutta, 1949, vol. II .

-ALEXANDER CUNNINGHAM : ARCHÆOLOGICAL SURVEY OF INDIA. REPORT OF A TOUR IN THE CENTRAL PROVINCES, 1873-74 \& 1874-75, CALCUTTA : OFFICE OF THE SUPERINTENDENT OF GOVERNMENT PRINTING . 1879, VOL IX .

-BROWN, PERCY: INDIAN ARCHITECTURE (The Islamic Period) TARAPOREVALA'S TREASURE HOUSE OF BOOKS- BOMBAY .

-Briggs, John.," History of The rise of the Mahomedan Power in India ,London, 10 
-EDWARD CLIVE BAYLEY, THE LOCAL MUHAMMADAN DYNASTIES. GUJARAT, LONDON:1886 .

-HAIG, WOLSELEY: THE CAMBRIDGE HISTORY OF INDIA VOL III "Turks and Afghans" CAMBRIDGE, AT THE UNIVERSITY PRESS, 1928

- HAROON Khan SHERWANI: THE PAHMANIS OF THE DECCAN , International. Printers, Hyderabad - Deccan- India

- J. ALLAN, M.A. The Cambridge shorter History of India , CAMBRIDGE, AT THE UNIVERSITY PRESS,1934.

- John Burton, :Indian Islamic Architecture ,Edited by : George Michell, LEIDEN . BOSTON, 2008. P 74 .

-Law , Narendra Nath, Promotion of Learning in India during Muhammadan Rule , new delhi , 1916.

- THE IMPERIAL GAZETTEER OF INDIA,VOL XV, KARACHI TO KOTAYAM , NEW EDITION , AT THE CLARENDON PRESS, OXFORD 1908 -W. F. Sinclair : Rough notes on Khandesh, Indian Antiquary! Vol. 17 (1875), Bomby,P. 108., Gustav Oppert : " On the Original Inhabitants of Bharatavarsa or India " ORIENTAL PUBLISHERS, PATAUDI HOUSE, DARYAGAN1, DELHI . -S.C. Misra : The Rise of Muslim power in Gujarat, A History of Gujarat from 1298 to 1442 , Asia publishing House New York.

-SPOONER, D. BRAINERD : Annual Report Of The Archaeological Survey Of India 1922 -1923, universal library .

-GAZETTEER OF THE BOMBAY PRESIDENCY VOL.1,PART.1 History of GUJARAT , Government Central Press (Bombay) 1896 .

-GAZETTEER OF THE BOMBAY PRESIDENCY VOI XII .KHANDESH PRINTED AT THE GOVERNMENT CENTRAL PRESS, Bombay, 1880 .

و - شبكة الأنترنت

https://ar.wikipedia.org/wiki/بنغال

https://en.wikipedia.org/wiki/Vadodara . 